\title{
Islamicates Volume I
}

Anthology of Science Fiction short stories inspired from Muslim Cultures

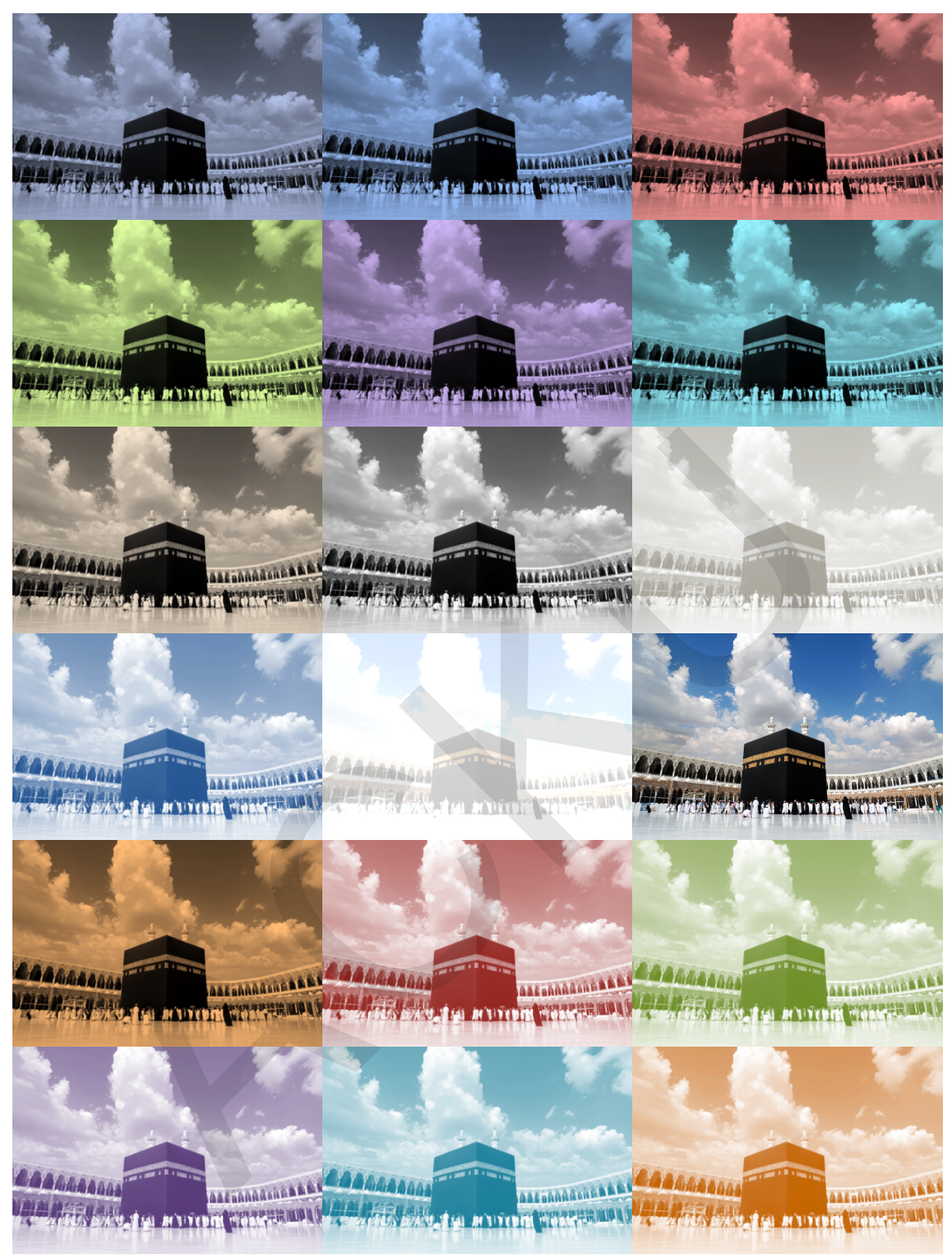

Muhammad Aurangzeb Ahmad (Editor)

$2016 / 1437$ 


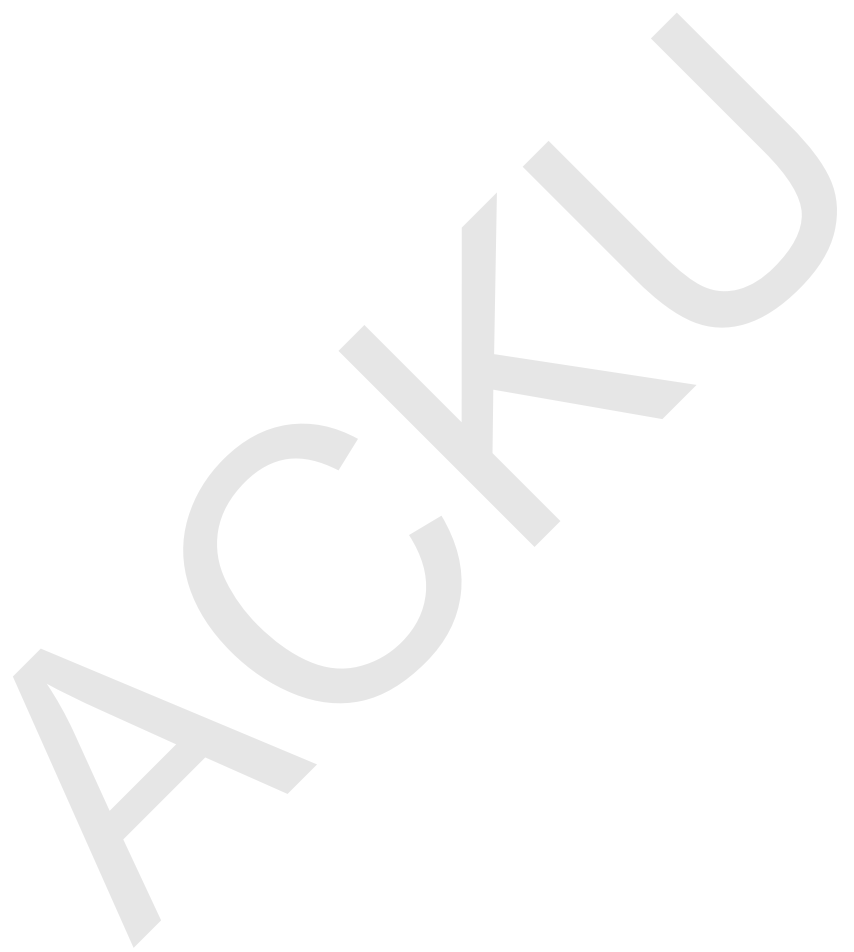


Mirza Book Agency 2016

ISBN-13: 978-1537372105

(@) $\mathbb{Q} \Theta \Theta$ This work is licensed under a Creative Commons AttributionNonCommercial-NoDerivatives 4.0 International License. 


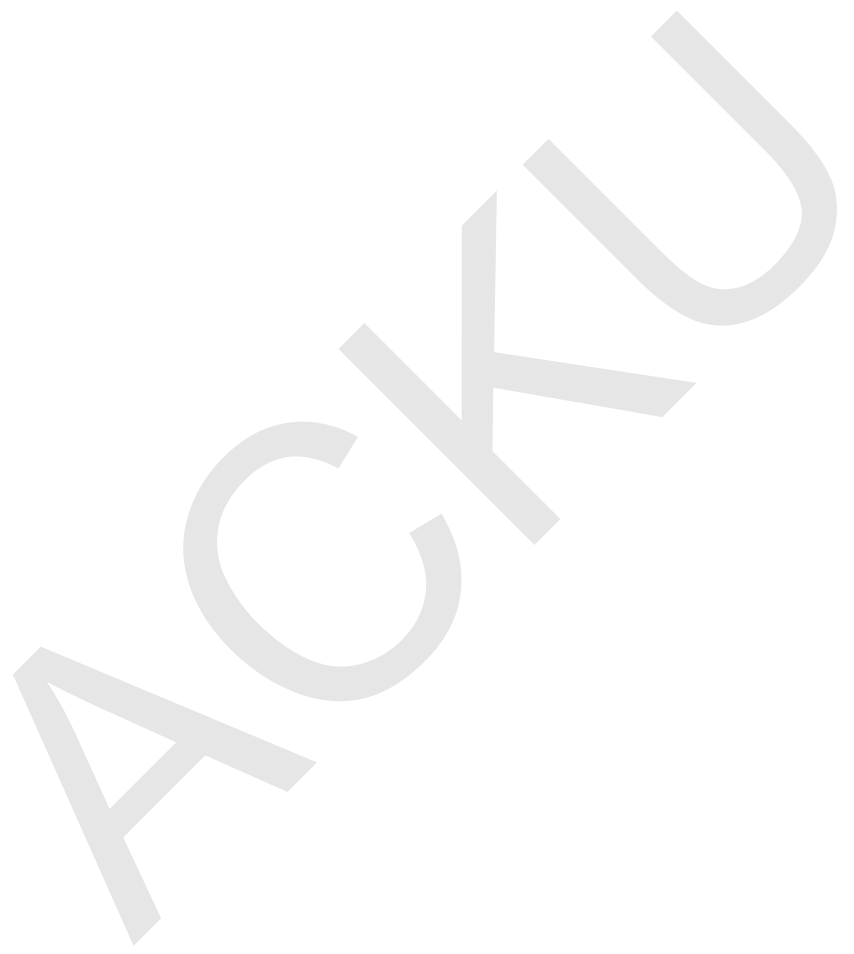




\section{Preface}

The academic Sherman Jackson observed that culture is frequency through which religion travels. While some people either in their naiveté or rigidity would think that culture and religion are separate and at loggerheads, it is true that one cannot have religion with a culture. All religions require a culture for their manifestation. The Islam and Science Fiction project was started in 2005. The main impetus behind the project was to fill a gap in the literature about Muslims and Islamic cultures in Science Fiction. Thus the focus is on the cultures with Muslim majorities and not necessarily the religion itself, although there is overlap between the two. It would have been more appropriate to describe the project as Islamicate Science Fiction but given that the term Islamicate, even 70 years after its coinage by Marshall Hodgson, is still largely confined to academia I decided not to use it at the time as it may cause confusion. The project has greatly evolved beyond the initial scope and has expanded to include spreading awareness, fostering and promoting Islamicate Science Fiction. The current volume, which consists of stories selected from a short story competition with Islamicate Science Fiction themes, is part of the same endeavor.

The area of Islamicate Science Fiction has not reached maturity even after more than 150 years of Science Fiction coming out of the Muslim world and after just over a decade since the inception of the Islam and Science Fiction project. In the early years of this project I co-edited an anthology of Science Fiction stories, A Mosque Among the Stars, with the Canadian Science Fiction author Ahmed Khan in 2008. In the span of the last eight years not enough material has come out in this sub-genre, as one would have expected. With the goal of fostering new contributions in this domain and rallying our fan base the Islamicate Science Fiction Short Story writing competition was inaugurated. Given that this is the first time that this competition was held the response to the competition was quite overwhelming, we received a total of 78 submissions. The stories presented in this volume represent the collection of best stories that were submitted to the competition and come from a diverse set of authors and story setting. It is my hope that the current volume is the inaugural issue of Islamicates Short Story Anthology and there are many more that will come in the future.

The role of speculative fiction is to imagine alternate worlds in the minds of people, to make them question the way things are and how 
they could be. It is my hope that people will continue to write in the space that exists at the intersection of Islamic cultures and speculative fiction. The Islamic civilization has more than 1,400 years of history but it builds upon the experiences of civilizations that come before it. Thus there is a lot of great material that can be mined from its cultural corpus, which can be used for great storytelling. The current time period in Islamic history may seem like the dark ages but it may be something as benign as storytelling that can help us navigate the current waters and envision something different not just for Muslims but for all humankind.

The current volume is also the first one being released under the banner of Mirza Book Agency publisher, which will specialize in this genre of book. It is homage to my father from whom I have inherited a life long love of books. I wish he was here to see this volume. There are a number of people that I would like to thank for making the current volume a reality: Special thanks to the other judges of the competition, Handara Hankins, Rebecca Hankins, Ahmed Naumann and Noura AlNouman; all the people who generously donated to the fund raising campaign. Last but certainly not the least thanks to the community of the fans of the Islam and Science Fiction project for their loyal following. It is your kind words and support that makes this project worthwhile.

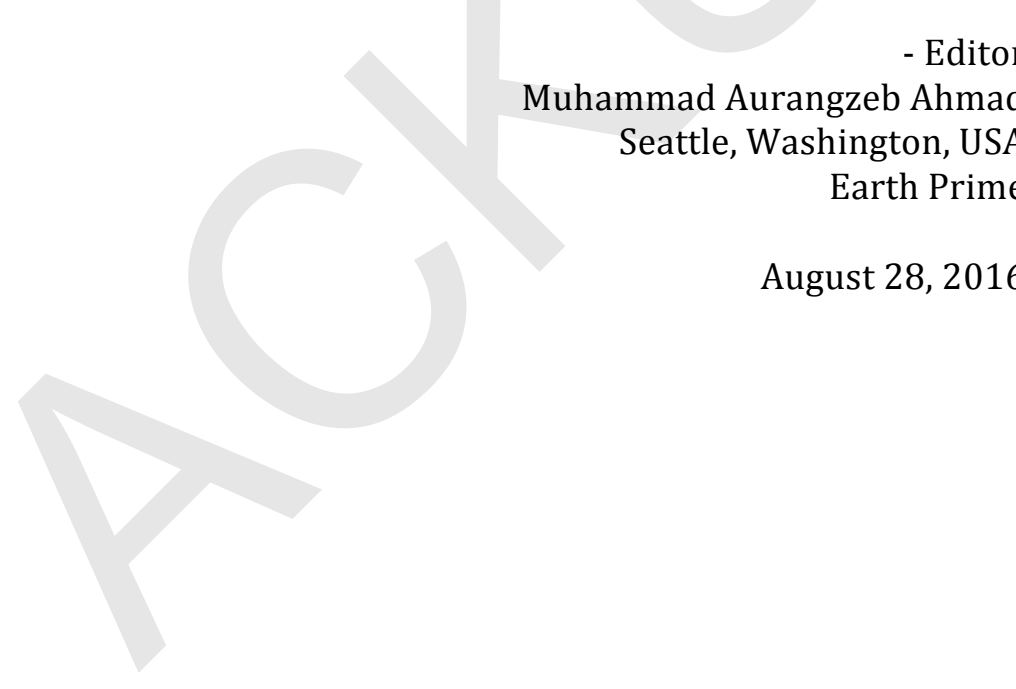




$$
\text { pe }
$$




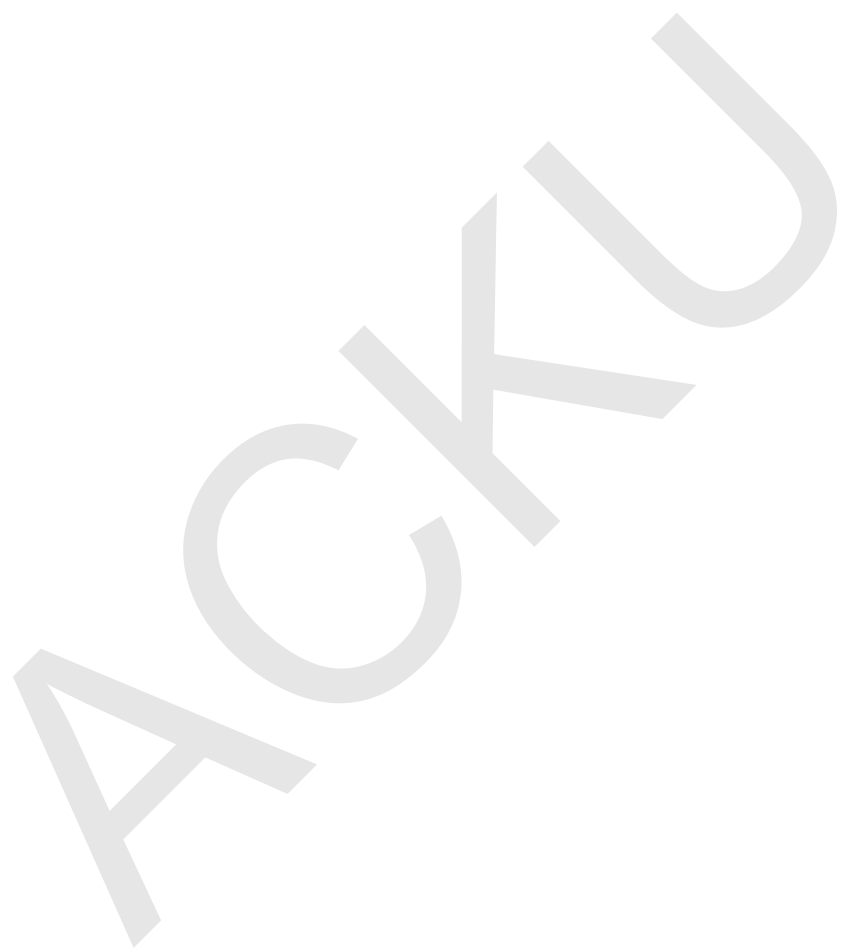


To my father, Mushtaq Ahmad Mirza, you are dearly missed. To my mother, Khalida, where would I be without you?

- Muhammad Aurangzeb Ahmad 


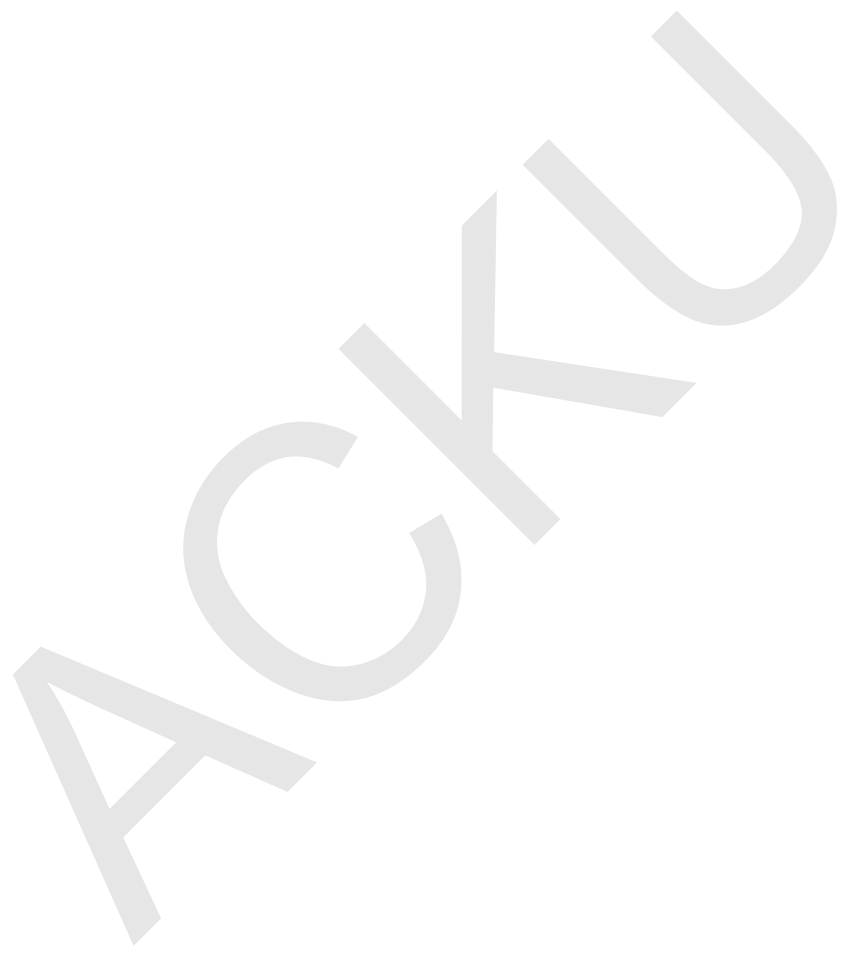




\section{Table of Contents}

CALLIGRAPHY

Alex Kreis

INSHA'ALLAH

11

R.F. Dunham

OPERATION MIRAJ

Sami Ahmad Khan

CONNECTED

Marianne Edwards

THE DAY NO ONE DIED

48

Gwen Bellinger

SEARCHING FOR AZRAIL

76

Nick 'Nasr' Pierce

WATCHING THE HEAVENS

88

Peter Henderson

THE ANSWER

Niloufar Behrooz

THE LAST MAP READER 116

Sazida Desai

THE END OF THE WORLD

143

Nora Salem 
CONGRUENCE

Jehanzeb Dar

PILGRIMS DESCENT

201

JP Heeley 


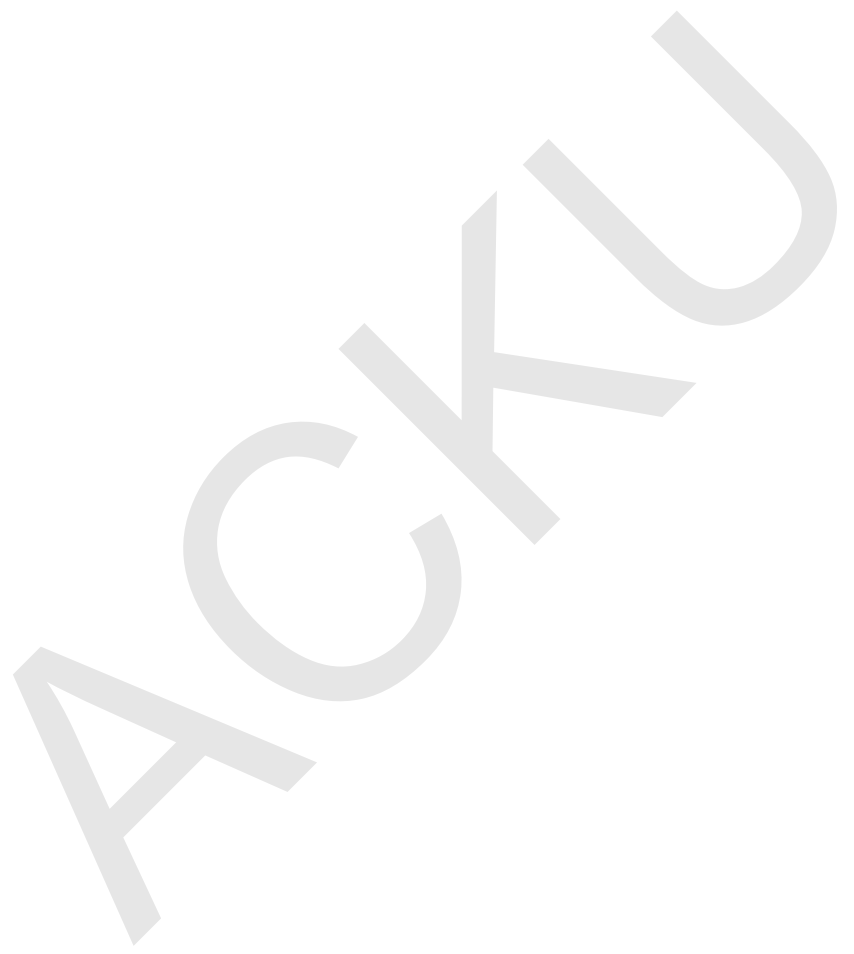




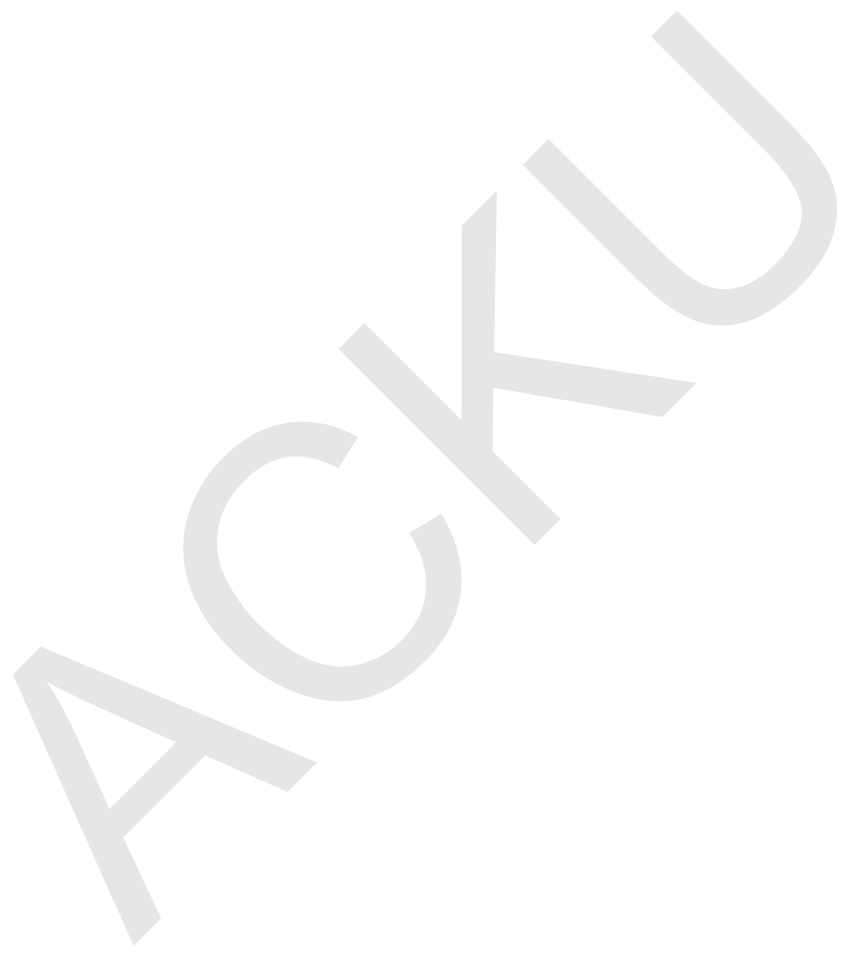




\section{Calligraphy}

\section{Alex Kreis}

Author Bio: Alex Kreis's birth was foretold by a witch but was otherwise uneventful. He was raised by homeopaths and got measles as soon as he got to college. He's stayed in a castle in Scotland, bought an ill-fitting sweater on the black market in Moscow, and got terribly lost in Cairo. He climbed to the top of Temple IV in Tikal just to see where George Lucas shot the Rebel Base in "Star Wars." He's a graduate of the Viable Paradise workshop and a former member of BRAWL, the Boston SF/F writing critique group. He lives outside Boston with his two children.

In the name of God, the Compassionate, the Merciful. I press my forehead to the tiled floor. God is Great! Eyes closed, I feel the tiles' pattern: interlocking stars of David and Solomon, upon whom be peace. The signs of those ancient prophets lie beneath us in our daily worship, just as the men themselves are the basis for the continuing revelation.

I take no solace in the thought. These tiles, all the tiles that cloak the bricks of this mosque in the seven colors, do nothing but remind me of my own imperfection, likewise hidden.

To my perpetual shame, I am the greatest of the tilemakers in the city of Isfahân.

\# \# \#

The day he first came, the heat rose off the kiln in waves. We had glazed the tiles and begun their second firing. Thorn bushes crackled, licking the kiln with flames and sending up a bitter black smoke. Perhaps if it had begun in any other way, it might have ended 
differently. Who but God can see, when the first seed is planted, how the leaves will turn?

"Master Naqash!" came a shout. I turned; my employer Jalal alDin Safarshā strode up the street, accompanied by a man I did not know. The stranger's beard was short and cut to a point, and he wore the small white turban of an educated man. But there was something of his dress or manner that made me think him a foreigner.

I greeted Jalal. It was he who first told me of the plan to raise the Darb-e Imam, a great shrine to 'Ali's descendants -- a gesture of defiance by the Sultan of Persia against the false-believing Arabs to the west and the Asian empires to the east. "Yes, my friend. You honor me and my workshop."

He turned the praise away with a hand. "Nonsense. To be in the presence of your art is a joy. But here, I grow rude; I must introduce you to your colleague." He half-turned to the man. "This is Musa ibn Muhammad al-Khwarizmi. He has studied at the Workshop of Herât, and he has traveled here to Isfahân to work for the Sultan."

So I was right that he was a foreigner, doubly so to be from Khwarizm and have studied in Herât. Worth traveling to, indeed; the Workshop at Herât produced some of the greatest tilework -- and craftsmen -- in all of the lands of peace. The city gleamed azure like the sky above.

Or so I have been told.

I grasped hands with al-Khwarizmi. We exchanged kisses on the cheek, but I had the first stirrings of doubt. I was the master in Isfahân; I had been charged by the Sultan himself to create the tilework on the Darb-e Imam shrine. Why was this stranger here, and why had Jalal brought him? "Welcome, Master, to my workshop." 
He inclined his head, as if he were thoughtfully considering the statement. "Ahh..." There was a quiet moment. Was he simple? "What color are you firing?"

I blinked in surprise. "Turquoise."

He strode over and held his hand near the kiln, then jerked it back. "Hot!" He turned back to me. "Two parts tin, two parts lead, three parts glass?"

I began to grow angry. "Yes, of course. And slain copper, as it is written in the Book of Those Brides That Are Gems and Scents."

He pursed his lips. "It is too hot - the color will run. You should burn white willow, with the bark removed so it does not smoke."

I would have argued with him further, but there was a look I did not like in Jalal's eye, and so I merely bowed and kept my silence. My workers looked on wide-eyed, though, and I angrily waved them back to work.

It was bad enough, but it would have been bearable if he had not been right.

\# \# \#

I saw him again at the morning prayers. As we lined up to enter the mosque, the sky was pale but the sun had not come up. I looked at the brickwork. Early yet, and it appeared to be a featureless surface of the reddish-brown color we call sandalwood.

I watched the back of his head. Was he looking? Would he see? Already, the thought of his reaction warmed my heart. He would see that I was no mere student. He may have studied at the workshop of Herât, but he did not know every trick.

The line moved slowly, as each man performed his ablutions; some merely rinsing their hands and arms, others performing the major 
ablution. The sun inched up and my anticipation became nearly unbearable.

I saw it before he did, of course; I was watching for it. Tiny lines of shadow emerged on the mosque wall, each cast by a brick so-slightly set out from the wall. As the angle of the sun changed, the lines thickened and joined, and formed a sunburst made of shadow. The lines of the sunburst were themselves composed of the angular calligraphy called kûfî, spelling out words from the thirteenth sura: "Before God prostrate themselves all things in the heavens and the earth, as do their shadows in the mornings and the evenings."

The crowd noticed and murmured -- although few of them could read or could appreciate the subtlety of the calligraphy -- and I swelled with pride. al-Khwarizmi turned to me and bowed deeply. And in that moment of victory, I thought that I had won.

\# \# \#

Weeks passed and my days filled with the regular pattern of shaping bricks of clay; firing them in the kiln; mixing precise measures of lead, tin, glass, antimony, copper, iron, or the like. It is one of the great miracles of my craft that whatever the mix of ingredients, the resulting powder is always grey. We mix it with water and apply it to the fired bricks, then return them to the kiln for a second firing. Only the addition of the great heat in the kiln transforms the glaze into its destined place among the Seven Colors: turquoise, azure, white, sandalwood, green, red, and black.

Finally we were ready, and I and my workers wheeled the first batch of tiles to the Darb-e Imam, the shrine, still under construction. The northern tower was complete, and we would cloak it in an intricate five-fold symmetric pattern of red, green, and turquoise, with words of 
the prophet inscribed around the band. My men had already built a wooden scaffolding around the tower, and we were ready to begin the process of attaching the tiles to the bare brick.

But what was this? As we approached, I saw another unexpected set of scaffolding on the tall pointed entrance archway. Other workers were on their back, lifting tiles into place on the ceiling of the archway. Angry, I strode toward them intending to demand an explanation, but I came short when I saw Master al-Khwarizmi up there with the workers.

Then I saw the tilework. Two trees, one on each side of the arch, grew and twisted up the walls. Their limbs and leaves embraced diamonds and stars, until straight above, night-blue and brilliant white tiles mirrored the sky. I was impressed; the quality of the colors was the best I had ever seen, with multiple bands of colors even on individual tiles. How had he done that?

I peered closer to see if I could puzzle out the trick, then saw that a single band of color spanned across many tiles. The tiles themselves were not mere squares, but hourglasses, elongated hexagons, and rhombuses, cunningly interlocked. I followed the band of color from tile to tile, saw it meet another. I stepped back and blinked. Suddenly I saw it. The lines were not mere space behind the leaves and twigs of the twin trees, but calligraphy, in an elaborate cursive that both formed the trees and was created by it. "God sets forth a parable like a good tree, whose root is firm and whose branches are in heaven." The Fourteenth Sura.

I found that I was on my knees, and tears ran down my face. This was artistry beyond my skill. In the craftsmanship, clearly, but even in his holiness and his embrace of color and form. I had never created anything so perfect, and what was worse, I never would. 
\# \# \#

I wandered the quarter, aimlessly, until long after the sun had set. Distantly, I heard the muezzin's call to prayer, but my feet did not carry me to the mosque. It is permissible if traveling in the desert to postpone prayers, and I reasoned -- knowing it a poor excuse even at the time -- that I was just so traveling in a desert of the mind.

I found myself at al-Khwarizmi's workshop. I had never been here before, but knew its location from overheard conversations among my workers. I looked at the stars - it was well after midnight. I knocked.

Al-Khwarizmi came to the door and wordlessly led me up a flight of stairs into a study. Even then I was unsure what I would do: berate him? Confess my shame? Plead with him to share the secret of his mastery? And yet I knew all of those words were mute and would beget nothing.

I had even opened my mouth to speak when I saw the designs laid out on the floor. Tiles, perfectly square, but each had layer upon layer of figure, leaf, and calligraphy. I looked at him and he indicated permission. He had yet to speak a word to me, but his art was nothing but words.

The designs were only charcoal on parchment, but I could see in my mind the color. Yet the pattern was not revealing itself to me. I moved two of the tiles together, and by sheer chance -- or so I thought -they matched, the cursive lines forming the word "path." I put another on top, and saw the word "master" overlay the first. Again and again I slid a tile next to the growing pattern before me, each time without effort matching the existing lines.

"What is this?" I whispered. "Is this enchantment?"

He finally spoke. "No enchantment. There are only thirteen 
tiles."

I did not understand at first. "Such a small pattern -- " But then I looked down, and saw that while I had indeed used the same tiles many times, different combinations had formed different words. There might be only thirteen different tile designs, but the overall pattern might be much larger.

"How large?"

He smiled. "I don't know. I haven't finished it."

This was beyond belief. "How can you make a pattern without seeing the whole?"

He waved his arm, encompassing the pattern, the studio, perhaps even the quarter and the city. "How can you not? Only God can see the whole. I see only the beginnings, and I can only follow them through to the end."

"But these words, these verses... I do not recognize them."

"They are new."

I looked at him. In that moment he seemed inhuman, perhaps possessed by a djinn, and it did not seem impossible to me that he was a poet as well as a master craftsman. "You wrote these?"

He shook his head again. "No, or not as you mean it. I created the tiles from words from the Holy Qur'an. Put together, they form new verses. It is as if God is still speaking."

I spat. "Do not say such things! You contradict yourself - the Qur'an is the final revelation. There can be no more." My old anger at him returned. "Do you think yourself a prophet?"

"I am no prophet. I merely follow the designs until I come to the end of the pattern."

I stood and stared at him, empty of words once more. Then I 
turned and stormed down the stairs and out, my mind a confusion of heresy and wonder.

\# \# \#

I slept late the next morning and missed the dawn and morning prayers. Only the muezzin's third call woke me: God is great! I threw on my clothes from last night, wrapped my turban around my head, and staggered into the street toward the mosque. People looked at me then averted their gaze, as if ashamed for me. And in truth I felt as if I had been drinking, although I had not touched anything last night. But my head ached and my eyes were bleary. Did I remember right? Had alKhwarizmi said those mad words, or was it only a fever dream?

I scrubbed my body in the major ablution but felt no cleaner. As we sat at prayer, I could not help but follow the patterns in the rugs, the tiles, and think of his words last night. Could it be true? Could the mind of God be found in a pattern? Those words -- how long did that pattern go before it repeated? I must have placed several dozen, but no regular pattern had emerged, although maddeningly close.

Jalal was the prayer leader, and I waited outside the mosque to speak with him afterwards. I spilled out some form of my confusion, although I could barely manage to ask it coherently. Yet he seemed to understand.

"At the madrassa, we studied mathematics as well as theology. There are many kinds of patterns, and many kinds of symmetry." I knew this, of course; no tilemaker could be ignorant of the many forms of symmetry. "But there are other patterns. Some do not appear to repeat, although scholars do not understand them and cannot prove it."

"Then how can we know if they will ever repeat?" Even as I asked the question, we both must have sensed that it was not my real 
concern, that I asked these rarefied questions of mathematics because I dared not speak of anything else.

"The mathematicians have proved one thing: we cannot know. All we can do is to lay out the pattern. If it repeats, then it does. If not, we continue until it finally does repeat or we grow tired. Even the tiniest difference at the beginning may cause the pattern to take a different shape; one turn of a tile may make the pattern repeat, while another may open out forever. You cannot know."

I whispered, so low that Jalal put his hands on my shoulders and put his ear to my mouth. "Does God know?"

He pulled back, but without letting go. "God is the pattern that never repeats." He squeezed my shoulders one last time and left me.

\# \# \#

I returned to the construction site of the Darb-e Imam. My workers were there, attaching tiles to the tower in a pattern I had laid out a lifetime ago. It seemed bizarre -- wrong, even -- that they went on with their work as if nothing had changed, merely repeating their own pattern of work day after day. And yet they greeted me in the same fashion as always, bowing with hand over heart, and made the same jokes, and called out the praises of God in the same manner. I had changed, though, like the seed in spring ready to send out its tendrils and leaves to become the world.

I wandered away from them and over to al-Khwarizmi's site. He was not there, but his parchment was, the markings of the first few tiles set in their place on the floor, ready for the final application of the glazed bricks. I studied them for a moment, and thought of the words of Jalal.

I looked around. Workers filled the site, shouting, or 
hammering, or noisily laughing, and yet I seemed to be alone, here in the quiet center of the activity. I bent down and gave one of alKhwarizmi's tiles a quarter-turn. The edges lined up again, but the words had changed. What pattern would this create, I wondered. Then someone approached and I hurried away to retch in the dirt.

$$
\text { \# \# \# }
$$

God is Great! I raise my palms and repeat the words of the prayer leader, but my thoughts are elsewhere. Often I visit alKhwarizmi in the plains far out of town. I bring him food and water, and sit on a stone and watch him. He inscribes his patterns in earth and stone, following his rules and seeing if the pattern will ever repeat. I do not believe it ever will; I believe that he has found the word of God, which is the never-ending revelation of the world.

I press my forehead to the tiled floor. To my perpetual shame, I am the greatest of the tilemakers in the city of Isfahân. In the name of God, the Compassionate, the Merciful. 


\section{Insha'Allah}

R.F. Dunham

Author Bio: R.F. Dunham writes with one purpose: to take you places you've never been before. That might be a distant fantasy land, the far reaches of space, an alternate earth, or simply to an idea you've never encountered. A student of language and culture, Dunham's stories will pull you into complex worlds that challenge your perception of your own surroundings. R.F. lives in the foothills of Central Virginia with his wife, two cats, and a Newfoundland dog. If he's not writing, he's probably brushing that dog. Any remaining time is spent playing jazz trumpet and hiking in the Virginia countryside. You can learn more about R.F., get connected, and sign up for free books at DunhamWriter.com.

The teapot screamed for his attention as Khafid shuffled around his kitchen. The space was far too large for him and Aliyaa told him so every time she visited. Still, he refused to sell the apartment. It was home and it was where he would stay until he died, insha'Allah.

Khafid stooped to pull the pastries from the oven, ignoring the popping joints and creaking back that told him he was too old for such things. He couldn't afford to be slowed by his age, not today. Aliyya was coming to visit and he had to be ready.

The teapot's scream had become a frantic shriek by the time he switched it off. He reached for a cup so the tea would have time to steep before--

A crisp knock on the door announced Aliyya's arrival.

Khafid glanced at the clock. She wasn't due for another fifteen minutes. He still had to steep the tea, set out the pastries, prepare the 
sitting room, and probably a few other things he was forgetting. He wasn't ready. He made his way to the front door, pausing to smile at the picture of Samraa that hung on the wall in the entryway. She always used to make this hosting business look so easy. Yet he couldn't even arrange a proper welcome for their own daughter.

He opened to door to see the top of a head thick with dark hair.

A moment later, Aliyya looked up from the screen of the nabu'a in her hands, bright smile lighting up her face. "Dad!" She stepped inside and threw her arms around Khafid's neck before he could even shut the door.

"You are early," he said, once she'd released him.

Aliyya laughed. "You would have known I was going to be a little early if you'd just use your nabu'a every once in a while."

"Bah." Khafid waved a hand to dismiss the notion. "I'm just making tea and getting ready to set out some snacks." He made his way back toward the kitchen, expecting Aliyya to turn toward the sitting room. But when he reached the kitchen, she was still behind him.

"I don't know why you refuse to use yours," she persisted. "You did invent the things. And they make life so much easier."

Khafid ignored her and began pouring two cups of tea.

Every visit always came to this. Though not usually so fast.

He handed Aliyya her cup. "If you'll make yourself comfortable in the sitting room, I'll be right in with--"

"I'm not a guest, Dad, I'm your daughter. You don't have to serve me."

"I insist." He smiled at her. "It's what your mother would do." 
Aliyya returned the smile. She couldn't argue with that, and Khafid knew it. "Fine. But don't take too long, I've got something to tell you."

He joined her two minutes later, tray of pastries balanced delicately on his right hand while he carried his own cup of tea in his left.

"Dad, you should've let me get that." Aliyya jumped up and snatched the tray from his hand before he could protest.

Khafid sighed and sat down. "One day, you'll learn to let an old man have his way, insha'Allah."

Aliyya giggled as she set the tray on the floor table between them. "Why do you say things like that?"

"A man has to have dreams," Khafid answered. "Even an old man without much longer to live."

"Not that," she said with a shake of her head that sent black hair bouncing around her petite face. "The other thing. The 'if Allah wills' thing. And you've got plenty of time left to live, Dad. I checked."

"I say it to show respect for Allah," Khafid answered, ignoring her second statement. They both knew she could do no such thing. Not with the algorithms running the current versions of the nabu'a. "What is this news you have for me?" It was time for a change of topics.

Aliyya's face brightened right away. "I've got a job interview. To join Dr. Assad and his team in Europe."

"That would be an honor," Khafid said. And it would. Just not the kind of honor he wanted for his only daughter.

"It's super competitive and I know there's not much chance I'll get it, but--"

"Insha'Allah," Khafid said, "it will be yours." 
"Dad, everybody knows it doesn't work like that now."

Khafid kept his breathing even and steady but he could feel his pulse accelerating. "Everybody knows no such thing."

She held up the nabu'a, affixed to her hand as it always was. "Yes, we do. You proved it."

Khafid sighed. He was doing a lot of that lately. "I proved nothing."

Aliyya was still waving the cursed device in his face. "You proved that we can take our fate into our own hands. You proved that life is the sum of our choices."

"Bah." He shooed the thing away. "Life is what Allah wills."

Aliyya lowered her nabu'a but did not set it down. Her eyes softened until they looked almost empathetic. "Did Allah will what happened to Mother?"

Khafid would have stood to his feet and walked out but he'd only just sat down and he'd been standing for so long already. Instead, he held Aliyya's gaze, keeping his jaw firmly set to prevent his lip from quivering. When he couldn't formulate a suitable response, he forced a smile, hoping to end this line of conversation for good. "You will do great with Dr. Assad."

A frown flickered across Aliyya's face at the deflection but it was replaced by a smile a breath later. "Thank you, Daddy."

Their conversation wandered in more pleasant directions from there. Aliyya's friends, her recently completed studies, how she was spending her time now that those studies weren't around to demand so much of it. 
When the time came for her to go, Khafid was resolved to make their parting as smooth as possible. But the words came to his lips so naturally, he didn't have a chance to stop them.

"If you get the job, then tomorrow we will celebrate, insha'Allah." He winced, bracing for Aliyya's inevitable protest.

But she only laughed. "I've run a ton of scenarios, Dad," she told him. "My chances aren't very good."

Then she was out the door before he could offer any additional fatherly encouragement.

Khafid's head jerked up from his tea at the sound of a sharp knock on the apartment door. He didn't have to wonder who it was. He didn't get may visitors, and he would recognize that crisp rap in any instant even if he did.

Sure enough, when he opened the door, Aliyya's smiling face was there to meet him.

"You should have let me know you were coming," he said.

"So you could exhaust yourself preparing for me again?" She gave him a quick hug as she slid into the apartment. "Not a chance."

Khafid frowned at her even though he knew that he couldn't have handled another afternoon of hospitality preparation. He might know that, but he wasn't going to admit it to his daughter. "Tell me next time," he said.

"Dad."

"I insist."

Aliyya shook her head but she was still smiling. "Fine. I promise to give you some warning."

"And don't come early," Khafid added with a smile of his own. 
"No promises there." She took another two steps farther inside then stopped and turned back to face him. She was bouncing lightly on the balls of her feet, smile splitting her face from ear to ear.

"You got the job?" Khafid asked, doing his best to infuse his voice with excitement he didn't feel.

Aliyya clapped and gave a rapid series of nods. "Yes!"

Fate or no fate, Khafid had known, with confidence only a father can posses, that Aliyya would get the job. He could think of any number of better uses for her skills than working with Dr. Assad to extend the reach of the nabu'a devices beyond a mere three choices into the future, but there was no denying that she was perfect for the job.

He took the fact that Aliyya's nabu'a had given her such slim chances of securing the position as proof that the devices were not as accurate as the world wanted to believe. Proof that man's destiny was shaped by forces beyond his understanding. Not so many years ago, he would have interpreted the mistake as a flaw in his algorithms. Funny how he was relieved to find an error in his work now. There was a time when the very idea would have launched him into a frenzied, all night effort to fix it.

If only he could take back a few such nights. Then maybe the nabu'a project never would have reached such heights of success. Or inspired such depths of blasphemy.

Once they were sitting and Aliyya had a cup of tea for herself, she told him everything she knew about her new job. The lab where she'd be working in France and the few details she knew about the project ahead of time. Khafid listened, doing his best to appear as enthusiastic as she was about the whole thing. 
In truth, he'd never cared about predicting the future, not even in a limited way. The whole thing was just a project to him, an exploration of the relationship between math and human decision making. It started with the realization that there were only so many choices a person could make. From there, quantifying them and extending a few choices down the path was just a matter of getting a powerful enough processor. Now that such processors could fit in the palm of a child's hand, the technology was everywhere.

Khafid had walked away from the project years ago, when Samraa first got sick, and long after it had been concluded that going beyond three choices into the future wasn't possible. He'd always thought the ongoing research was focused on nothing more than packaging the technology for the public but, based on what Aliyya was telling him, his former student had far more ambitious plans than any Khafid had ever dreamed of. Dr. Assad was now the foremost researcher in the field and he wanted to expand the algorithm to predict global events and the outcome of political campaigns.

Khafid doubted he would succeed, but what did he know anymore?

He might be the man who gave the world the ability to predict the future but his own foresight had proven inadequate countless times. He never began to anticipate how his invention would affect the world, how it would shake people's faith in Allah himself. He certainly never imagined his own daughter would be among those to so casually dismiss Allah's hand in her life. Or that his wife would die in such a slow, agonizing manner.

Khafid gave a quick shake of his head to stir himself from the somber reflections and focus on his daughter. 
"It's going to be amazing, Dad," Aliyya finished. "Wait until you see what we accomplish."

"I'm sure you will do many wonderful things, insha'Allah."

Aliyya rolled her eyes, not much, but enough. "Dad, we will do wonderful things because we do them, not because Allah wills it."

Khafid held in a sigh and raised his hand. "Enough. Not tonight. Tonight, I will enjoy what time I have left with my daughter."

Aliyya frowned and her eyes narrowed. "Time you have left? Did you use your nabu'a?"

Khafid's laugh deteriorated into a hacking cough. "There are some things you don't need a nabu'a to predict."

She relaxed somewhat but continued to watch him. "Will you use it while I'm gone?"

"Aliyya, I--"

"I know, I know, you never use it. But please, just to make sure you're still..." She let her voice trail off but Khafid knew what she'd been about to say.

"Insha'Allah, I will be here when you return."

She shook her head. "That's not good enough for me and you know it. We make our own fate, Dad. So just make sure yours is to be alive when this job is over. Please?"

Khafid nodded. What else could he do in the face of a such a request from his daughter?

$* * *$

The subdued beeping of his phone stirred Khafid from his nap but not in time for him to answer the call. By the time he came fully alert and snatched the phone off the table next to his chair, the tone had fallen silent and the screen was flashing Aliyya's name. 
"Bah," Khafid grunted as he pushed himself to an upright position and jabbed at the screen the call Aliyya back.

She answered on the second ring. "I didn't wake you up, did I?" Aliyya asked, her voice dancing with the hint of a teasing edge.

"Of course not," Khafid said, knowing she would see through the fib. "You know how slow I am these days. Couldn't get to the phone in time."

"Whatever you say, Dad." He could hear the smile in her voice and it made him smile as well.

"It's good to hear your voice," he said warmly. And it was. She'd been gone for six months and this was only the second time she'd been permitted to call him. Assad seemed to have put a whole mountain of security protocols in place. It hadn't been like that when Khafid was running the project. Then again, the stakes were much higher now.

"Yours, too. I miss you, Dad."

He started to reciprocate but Aliyya moved on before he could.

"I've got incredible news." Her voice was excited but it dropped down to a low whisper. So low, it made it difficult for Khafid to understand her.

He covered his exposed ear and hunched over to block out any extraneous sounds. "Why are you whispering?"

"I don't have time to explain, but we had a major breakthrough." That explained the hushed tones. "Are you authorized to tell--?" "Just listen, Dad," Aliyya insisted. "We can go beyond three choices now."

Khafid blinked, torn between shock, pride in his daughter, and fear at what this might mean. "How far?" he managed to ask. 
"We're not really sure," she admitted. "But I tested it and I had to share the results with you."

He had to smile. He might not approve of the work Assad was doing anymore, but he had to admit it felt good that his daughter was so eager to tell him what was happening.

The smile was chased away a moment later as the implications of what he was hearing settled in on him. People were already convinced they held their fate in their own hands after gaining the ability to predict the future in a limited degree. If the capabilities of the technology were extended even farther, Khafid couldn't begin to imagine the consequences. Would people even bother to attend mosque anymore? Would they pick up the holy Koran? Would--?

"Don't you want to hear the results?"

Khafid blinked and focused his attention back on Aliyya's voice. "I thought you just told me?"

"No, that was the news. The results are what my test told me about the future."

He did not want to hear the results. Meddling in the future had been a mistake, still was a mistake, and he wanted no part in it. Better that he not know what harm the arrogance of his youth would give birth to next.

But Aliyya was already going on. "You're going to be just fine when I come home at the end of the year."

A faint hint of the smile returned to Khafid's face. Aliyya had a chance to look into the future and see whatever she wanted and she'd chosen to check up on him. Meddling in the affairs of Allah or not, the gesture was a sweet one. "Then we will have a grand celebration when you return." He paused a beat, then added. "Insha'Allah." 
He could hear Aliyya's eyes rolling. "Dad!"

$* * *$

Khafid was awakened that night by the sound of his own coughing as smoke filled his lungs. Flames licked at the walls of his bedroom, curling around the door and dancing on the ceiling. They were blazing hot and roaring so loud he had to wonder why he hadn't heard them sooner.

The panic that swelled in his chest lasted only an instant before it was replaced by a deep peace. He lifted himself to a sitting position with the same slow, deliberate motions he always used, and watched as fate came for him. His body would perish but he now knew to be true what he'd believed all along.

Not that his faith had ever been shaken. No matter how firm a grip the world thought they had on the future, he'd always known it was more complicated than it appeared. Still, after standing his ground on that belief for so long and watching as the faith of entire nations crumbled, the reassurance was welcome. So welcome, that he wasn't bothered by the fact that it would cost him his life.

A brief pang of sorrow disturbed his peace when he thought of Aliyya. She'd already lost one parent to tragedy and now fate had conspired to take another from her. But his concern evaporated in the next heartbeat. This was best for her. She would see now. All was as Allah willed. And only as Allah willed.

Khafid closed his eyes as the flames reached his bed, comforted by the knowledge that his future, and more importantly, Aliyya's future, rested in the hands of Allah. 


\section{Operation Miraj \\ Sami Ahmad Khan}

Author Bio: Dr. Sami Ahmad Khan read Literature at Delhi University, completed his master's in English at Jawaharlal Nehru University (JNU), and then went to the University of Iowa, USA, on a Fulbright grant. Sami holds a doctorate degree from JNU, and has taught at IIT Delhi, JNU and Iowa. His short fiction, research papers and articles have appeared in leading international and national magazines and journals across the globe. He has engaged in film, radio and TV production, and has scripted and produced features and documentaries for Prasar Bharati (India's public service broadcaster) among others. Sami's debut thriller "Red Jihad" won Indian National Book Trust's "National Debut Youth Fiction Award" and "Muse India young Writer Award (Runner-Up)". His second novel - "Aliens in Delhi" - is scheduled for release in late 2016. Sami is currently an Assistant Professor (English) at OP Jindal Global University, India.

Albuquerque Road, New Delhi, India

Local Time: 1630 hours

Date: 30th July, 1948

It was another beautiful, overcast evening. A soft breeze soothed her parched face, and Summaya Chughtai craned her neck in the direction of the dark, delicious clouds gathering above her. She saw a shaheen Falcon dive down to grab a hapless pigeon and majestically disappear into the depths of the unruly skies. 
Summaya unconsciously ran her hand through her short burgundy hair and returned her gaze to the street - desirous of locating familiar landmarks to navigate better. The road was too crowded for her liking, she noticed with a sigh. Exfiltration might be a problem if conditions remained the same, she thought. But Sumayya also knew that a confused, panicked crowd was the best ally one could have to escape, especially after what she was about to do.

Clouds played hide and seek with the setting sun; beams of sunlight filtered through the well-trimmed Ashoka trees which lined the avenue. An ancient rickshaw creaked past her. Its bare-chested, emaciated driver pedaled furiously, and turned back to leer at her frame. Summaya noticed the passenger, a medium-built, well-dressed man in his late thirties, ogle at her contemptuously. Propelled by a sudden gust, his flapping kurta $^{1}$ brushed against her right elbow. She instinctively shrank back. Years in military service had not made her comfortable with an alien touch.

Summaya suppressed a warm liquid moving from her stomach towards her mouth, burning her windpipe as it rose. Perhaps it had something to do with the bumpy aircraft ride on her way to Delhi.

Time jumps were never easy.

Summaya instinctively spat and wiped her mouth with her sleeve. She thanked Allah that her act didn't attract any undue attention - thanks to the gutkha²-chewing people around her.

She focused on the road - it was bustling with studied inactivity. People thronged the area and the crowds - a moving, breathing mass of bodies

\footnotetext{
${ }^{1}$ A kurta is a loose garment worn on the upper-part of the body.
}

${ }^{2} \mathrm{~A}$ form of tobacco which is consumed orally. 
- moved in the same direction she was headed towards. She slowed down to a leisurely ramble. A vendor was selling roasted peanuts right in front of her; temporary stalls had come up every few feet to serve milky, sugary tea. She continued walking, a bulky camera slung around her neck. Suddenly, out of nowhere, something hit her cheek - she cringed inwardly. Through the corner of her eyes, she could sense it was one of those wretched yellow wasps again - it caressed her face and sped away, its stinging venom, thankfully, still safely tucked in its belly.

The wasp. It reminded Summaya how she hated tataiyas in her home base Mushaf - yellow wasps which had the habit of emerging out of nowhere and lunging for unsuspecting victims. She narrowed her eyes and tried to make sense of the alien world around her.

The past few hours had been a blur, even by her standards. Summaya had been in the middle of a routine training exercise when she was ordered to scramble and report to the nearest hangar - in full gear. Once she reached there, Summaya had been bundled with a couple of others on a Buraq bound for India. They were briefed about their mission en route - that too by the Director General (DG) himself. To top it all, she had been made an Alif for the first time in her life.

Perhaps her hard work had paid off, she mused, or maybe it was pity by the top-brass. Summaya was assigned to be the leader of this operation, and was given two others to help her out. No names were exchanged as the trio flew from Sargodha to Delhi, but Summaya could tell their units from their bearing. She, the commander, was responsible for taking out the target. Bey, her second in command, was tasked with tracking the mark. Bey was a surly, middle-aged officer from the SSG - Summaya knew that the moment he had boarded the aircraft, put on heavy metal 
on his earphones, and looked right past her in the flight with an insolence only the Special Forces could have mustered. Summaya looked at Pey, her third team member. Pey - a tall, painfully thin man in his late twenties - sat in a corner, blissfully immersed in a copy of Qisasul-Anbiya. He was their transporter - it was his task to move the team to and from the target. His quiet, shifty mannerism made Summaya suspect that he might be from the Inter-Services Intelligence (ISI).

When they had received their orders en route, Summaya had inwardly baulked at first. Such hits needed months to plan and execute - this was big. However, she had been given her first chance to command a team. When she was given this task by the DG - who had briefed the team through a thought-link - she had only nodded and suppressed a shiver of zeal run through her spine.

As the aircraft made its way towards the international border, Summayya read more about the target and then distributed specific clothing to be worn during the operation. They then prepared for the jump - both of the Buraq and then of their para-drop. Summaya was in the process of reciting the fourth kalma when the AI onboard the Buraq pumped the aircraft full of gasses in order to acclimatize her for the jump. An uneasy drowsiness overtook Summaya's team.

It was time to play with the stars.

Army Strategic Temporal Command (ASTAC) Headquarters, Islamabad, Pakistan

Local Time: 1100 hours

Date: $7^{\text {th }}$ July, 2035 
Major Abdullah Yousafzai shifted in the aristocratic leather chair he was cocooned in, and looked around the exquisitely-decorated, opulent office space. A crystal chandelier hung in the centre of the room; rows of wooden bookcases - containing rare tomes on military history - lined the high walls and a rich carpet covered the marble-floor. Yousafzai knew the grandeur of the room was well deserved.

This was where it all had begun.

Almost a decade ago, Pakistan - like a few other zealous nations - had acquired temporal displacement technology from a Scandinavian corporation, that too at an extremely steep price. While the technology was still in its nascent stages, and was not fully tested, salivating governments had pumped billions into its research and development. The ongoing Sino-Pak-India conflict had taken a toll on the conscience of the South Asian sub-continent. The first to succeed in making this technology work was an American scientist - who, incidentally, chose to return to the country his parents were born in. Whether his zeal was driven by a desire to give back to the country of his forefathers, or the massive amounts of US dollars the ISI had transferred into his Swiss accounts, no one knew.

Within a couple of months, this technology was deemed safe for deployment in the field -ASTAC, thus, came into being: an elite corps, the crème de la crème of Pakistani Army, one which reported directly to the National Command Authority (NCA). There used to be a time when the NCA used to oversee nuclear deployment. However, with South Asia divested of all WMDs after a thorough UN-led combing operation, NCA had become a toothless tiger - until the ASTAC delivered the mother of all weapons into Pakistan's lap. 
Time.

Major Yousafzai observed the man sitting in front of him - his commanding officer. Lieutenant General Saif-ul-Islam, Director General of ASTAC, was a frail looking man with intense eyes, furry eyebrows and a hooked nose. A man of few words, and even fewer compunctions. Dressed in a spotless white pathani suit, Saif-ul-Islam sat poring over a cyber-file. Lines of worry were clearly etched on his bronze forehead; Yousafzai could see a vein throbbing in the general's temple. His mental gears, as they say, were grinding.

"Report." The general casually glanced up at Yousafzai, spoke in a soft, somber tone and returned to study the file.

"GHQ3 has not authenticated the order, sir. I reconfirmed," Yousafzai immediately complied.

General Saif-ul-Islam looked up at Yousafzai and shook his head in unhappiness. "Doesn't mean we can't go ahead."

Yousafzai felt the need to clarify. "Sir, GHQ has not authorized Operation Mi'raj."

Saif-ul-Islam merely smiled. "Screw GHQ. This is straight from the NCA, Major."

“But sir...protocol demands...” Yousafzai spluttered.

Saif-ul-Islam waved a dismissive hand at Yousafzai. "Override GHQ. How many more do we lose before the Neo-mujahideen realize they've fucked up big time...again? Do you want this bloodshed to continue forever?"

${ }^{3}$ General Headquarters, or GHQ, refers to the top-brass of the army. 
Yousafzai squirmed uncomfortably. "No, sir. Of course not."

"We have to ensure fundamental changes happen in South Asian politics." Saif-ul-Islam remarked more emphatically than he usually did. Yousafzai could sense that General Saif-ul-Islam was not in favour of a military solution; this led him to assume he perhaps had his own axe to grind.

"Sir, without authorization we cannot..."

"I am authorizing you to activate Operation Mi'raj. I have talked to the president." Steel crept in the general's voice, "Scramble a Buraq. I will brief the team en route. This is a direct order."

Yousafzai nodded unhappily.

"Clear?"

"Sir... I still do not understand why we have to do this."

"The president and the NCA have their reasons, irrespective of what the GHQ might think. Preventing someone's death is in the strategic interests of the entire sub-continent."

Yousafzai's mind raced to make sense of it all. He had a gut feeling that the war would end soon enough - it was only a question of which country was able to absorb more blows to its civilian populaces. Yousafzai also knew that ASTAC had to be at the forefront of national defence - and time, of all the things, was fast running out. He knew ASTAC only had logistical and technical support for two temporal incursions. One had already been executed - successfully. The particulars of the second and last mission were being deliberated by senior officers at the GHQ. Almost all senior corps commanders, as 
Yousafzai understood, wanted the second team to stay back in India and use their knowledge of future events to strategically infiltrate systems, institutions and nations.

"But why, sir, if I may ask? Our first mission... keeping Quaid-i-Azam4 alive has already succeeded and..."

The general's eyes lit up as he cut his junior short. "Thank God we were able to send advanced medicines to help him. Baba-i-Qaum would live till the 1970s, inshallah!"

Yousafzai was not one to cave in so easily. "But sir, shouldn't we be focusing on more important objectives?"

"We need this." The general's voice suddenly become soft, as if all fight had been taken out of it. "Son, I ask you do this not only for me but for all of Pakistan. You will understand it in the long run. That man needs to live - and another needs to die. If this happens then the India we fight in '65 and '71 will be a very, very different one."

Yousafzai was a military man, after all. If he was told to do something, his mind didn't linger for long on the why of it, but soon came around to discussing the how.

"Who will be the Alif, sir? Anyone special you are looking for?"

"Send a woman. Easier access," General Saif-ul-Islam replied casually. "What about Chughtai? She deserves a shot at redemption."

"Wilco, sir.

Yousafzai could start making some sense out of the general's cryptic remarks. There was no use delaying the inevitable. He had realized the

\footnotetext{
${ }^{4}$ A title given to Mohammad Ali Jinnah.
} 
politics of it all was well beyond his pay grade - and his mental horizons. "I will assemble the team and prep them for briefing, sir."

"Good, thank you very much." Saif-ul-Islam muttered a bit sarcastically. The general was still a bit irritated at being questioned.

Yousafzai stood up, saluted the general, and walked out.

Saif-ul-Islam briefly smiled at his receding figure, and returned to his files, his eyes twinkling.

The hunt was on.

Albuquerque Road, New Delhi, India

Local Time: 1700 hours

Date: 30th July, 1948

Summaya woke up just minutes before their drop-point. The plan was to have them para-drop at a remote location just outside Delhi. Once on the ground, they were to catch local transport, pose as tourists and mingle with the crowd. It was not unheard of - history-laden Delhi was a tourist delight.

Things had proceeded as per plan, though Summaya could swear she had felt something really strange the moment she had jumped out of the Buraq - a specially modified Lockheed C-130 Hercules armed with a temporal shift device - and cleared the blue-green mist surrounding their transport since the moment it took off. Summaya had not been surprised when they had passed undetected through Indian airspace. A Buraq of 2035 AD would be invisible to radar technology of 1948 . No 
wonder the Indian Air Force had failed to scramble fighters to intercept her transport, she realized.

They had landed safely and then trekked to their rendezvous, where they were promptly met by the "leaguers" - sleeper cells of helpers who assisted the daily operations of her organization. The leaguers were right on schedule, with a smile on their lips and samosas in their hands. They then herded Summaya's team into an old bullock cart and dropped them at their predetermined positions.

A bark jolted her back to reality. She was back in a central Delhi street a long, long time ago. She cursed herself for getting distracted and looked at the source of commotion. A little, brown pup stood swaying on the pavement, eyeing the passing rickshaws. A crow came dangerously close to it and the pup backed off till it hit the leg of a man who sat on the ground.

She saw the malnourished, gaunt man, clad in a dirty loincloth, raise a glass of the tea at the brown pup and mutter some unintelligible phrases. Summaya watched in wonder as the pup, with its tail now wagging, trotted towards this man, who, in all likelihood, was a poor labourer. Summaya could tell this from his clothing - or the lack of it. He was just another of the million toiling souls from the subcontinent who tried desperately to somehow make ends meet - and failed.

The man reached for a packet kept to his left. The pup stopped dead in its tracks, afraid. The man merely smiled and beckoned the pup to come closer. Summaya came to a halt and watched the events unfolding in front of her with an open mouth.

The pup, having realized it was not going to be stoned, resumed wagging its tail and playfully bounded up to him. It put his paw on the 
man's dirt-caked feet and looked at his face. The man had, by then, opened the packet and taken out two moldy rusks. He dunked one in his tea threw it at the pup. The other, he put in his mouth. Summaya saw this man, on the cusp of acute starvation, give half of his breakfast to a hungry pup twice the size of his palm.

The mongrel lunged towards the food, slowly sniffed it with its little bulbous nose, and then cautiously licked it. Finding it edible, it shot the man a grateful look, clutched the food in its mouth, and ran away to safety under a stationary tanga 5 .

The man, too, got up, rolled a filthy white cloth in a bun over his head so it could balance the bricks which he carried at construction site he worked at - and walked away.

Summaya gently smiled, her heart feeling better all of a sudden.

“Target spotted," a voice rang in her head.

It was Bey, communicating to her on the earpiece she had plugged in her left ear.

"Be there in 5," she said in between hurried strides to no one in particular. She cursed herself for getting distracted. Summaya hit the road with a renewed zeal.

In a few, crisp moments, she was standing at the gates of Birla House.

The area was even more crowded than she had imagined. She saw scores of khadi-clad men trying to channel the crowd in an orderly fashion. She smiled at a volunteer and pointed at her camera. The bored volunteer saw a curvaceous red-head, stopped dead in his tracks, and

\footnotetext{
${ }^{5}$ A horse-driven cart used to ferry passengers and goods.
} 
started walking towards her instead.

"Are you...a tourist?" He shouted even before he was in range.

"International press," Summaya, trying hard to look startled, muttered in unaccented English, “...can I see him?”

The volunteer scrutinized her carefully; his eyes lingered on her camera for a moment too long, and then grinned from ear to ear. He took her hand and led her across the crowd, cutting through the shoving horde with a practiced ease, and got her waved across three police checkpoints.

Summaya saw Bey and Pey standing at their locations, trying not to stick out in this strange land.

The stage was set.

The volunteer took her to the very front and Summaya gasped at what she saw. People were standing on two sides of a narrow lane, leaving space for him to pass. The atmosphere was electric. Summaya had seen this many times, this was how many mass-movements began, but this was somehow different. People were charged up, yet there was also an intrinsic self-control at play. Had she not known better, she would have thought that the orthodox, eager Hindus, calm, bearded Muslims, and lanky, turbaned Sikhs, around her were actually there to pray.

"Visual at 8." Bey curtly barked at her.

Summaya started at the words. She scanned around and saw him. The target had walked right in front of her. An Indian male with an unsure gait with a face she was made to memorize.

"In sight," she acknowledged and clutched the camera firmly in her 
hands.

A loud cheer went up. An elderly man had come out of the house, along with five others who followed him respectfully. The thin, wiry man was dressed in a white dhoti and carried a walking stick. He was supported by two young women who helped him walk. The man wore spectacles and his eyes twinkled as he looked around. His lips split in a goodnatured grin and he bent low as people showered him with petals.

He was coming towards her. Before she could think any further, Pey reported in. "Get ready!"

Summaya stared at the scene unfolding in front of her eyes. The target moved to intercept the wizened old man. The group stopped reluctantly - someone sighed in frustration. The target bent down and touched the old man's feet; he patiently waited for the young man to complete paying his respects.

The young man got up and then threw himself at the old man's feet again.

Summaya could sense something radiating from this young man - the very same tightening of her heart that she had felt on her first combat mission.

A girl started walking towards the man to remove him from their path. She said in a cross, patronizing tone, "Brother... Bapu is already late."

The young man did not hear her. When the girl tried to stop him, the youth got up angrily and pushed the girl aside with a loud shout. Within the blink of an eye, he had reached for a Beretta M1934 semi-automatic pistol that he had concealed in his trousers.

He pointed the weapon at the wizened old man - who merely stared 
back at his assailant less with fear, and more with surprise and pity.

Summaya could hear a collective gasp. The man who they had congregated to see was under attack. Every single individual there was too shocked to react. Everyone - except Summaya.

Summaya, her senses honed, observed the split-second when the target's finger started to squeeze the trigger of his Beretta. This was the signal Summaya had been waiting for. She had already positioned the camera directly behind the target. She clicked and the shutter parted. A silenced bolt hit the target, incapacitating him instantly.

The target fell on the ground, writhing in pain. There was no sound from him. No one had seen the cyanide-laced, dissolvable microprojectile make its way from her camera to the neck of the target, causing death in less than five seconds.

The would-be-assassin had been assassinated moments before he completed his mission, ostensibly of a cardiac-arrest.

Mouths opened in shock; a scream thundered through the air. Footsteps. People had started running - some away, some towards the epicenter.

Summaya whirled back and started walking away. She knew she was above suspicion. Her hurrying away would be seen as a sign of fear and shock, not guilt.

“Done. Get out. Now!” Her earpiece buzzed excitedly.

She hurried away and was soon swallowed by the crowd. The target was dead. She had been successful on her first mission as Alif. She felt proud of herself. 
Before Summaya - and her team - left for their pre-designated extraction point, she vividly recalled the elderly gentleman bend down, sorrowfully gaze into the unblinking eyes of the target and paternally clutch his unmoving hand in a show of genuine sorrow. Summaya had seen enough death to know which sorrow was real - and which one was put on as a mask for the world to see.

The old man shut the target's eyelids with two bony fingers, felt the deathly still chest and painfully croaked to himself, shocked that a person had been murdered at his prayer meeting.

Summaya still remembered the two words out of the elderly gentleman's mouth before he was whisked away by his zealous supporters, worried that another assassin might pay him a visit. She could never forget how the old man looked into the dead eyes of the target and chanted two words that made her blood run cold, words which still echoed in her ears every time she closed her eyes and prepared to sleep.

Two short, crisp words, which sounded somewhat religious to her at first, but later acquired a meaning much, much deeper than that.

Two simple words.

"Hey Ram." 


\section{Connected}

\section{Marianne Edwards}

Author Bio: Marianne Edwards lives in rural France where she works as a writer and osteopath. Her work ranges from poetry, short stories, journalism, and web content. She is also working on a radio drama and a novel for young people that is an excuse to write about her passion for horses. She has two children with her intensely kind husband, who is also a writer. She also offers a feedback and copy editing service for work in progress and can be reached at mariannedwardswrites@gmail.com.

We are all in the prison of our own selves.

Even my job creating shared mindfields didn't change that.

I want to record every detail of the day we connected.

I want you to know who I am so you can know how much I needed you that day.

From your own cell you opened my door.

I love you.

On my tablet, the photo had dimmed to near blackness. The only bright spots that remained were our faces. Stress. I reached into my back pocket for my Anodyne ${ }^{\mathrm{TM}}$, but the pills were in the bathroom. Only the rich can have the perfect memories that unlimited storage affords. People talk wistfully about hard drives with hundreds of films and thousands of albums on them. I tapped the sensor in my palm and the image brightened again. If I didn't manage to save it somewhere in the next 24 hours, the last tangible proof that I'd had a family would be lost forever. You've changed your name, but in the photo Asma is 15, I'm 12, and our brother Alvand is already a young 
man. Our faces are serious but Mother has lifted her veil and smiles bravely, right at the camera, into the sun. We are all squinting, but she burns her eyes to look directly out at us from this photo. It felt like the end of everything at the time, but mother was smart - always well informed - she knew that moment would look like calm to us one day. She made us all put a copy on our phones. We're leaning against the Mazda. It had seven seats and air con, already a relic of our old lives. There are olive trees behind us that our ragged washing is trying to climb. A thin pipe stands in the dirt by the side of the road, ending in a tap. We were living out of the car by then. Maybe mum looks so thrilled because there's running water. I was thrilled because a horse had ambled over for a drink when it heard the tap running. So many dogs and cats were without owners - but a horse!

I had to hurry if I was going to back up the photo at work. I didn't want to be one of those people I have seen staring intensely at a tablet, on a bus, in the street, forbidding tears in case they blur that last moment with someone they have loved. Some people take digital deaths harder than the loss first time around.

The lift hadn't run since the ban ten years ago, so getting down the stairs always took 25 minutes, at least. That only left me 15 minutes for the bus ride. I always had to fight an urge to slide down the bannisters - the angle was wrong and I'd get jammed on the first corner. As I was pounding down the stairwell, a piece of the past came back so hard that I froze for a second. A wide stairway curls into a central courtyard. The walls are tiled. I have raced up four flights several times for the joy of whizzing down again and flying off the end into Asma's waiting arms. It must have been a huge house. The adults were laughing, so it's from before. Was it from Syria? Turkey? A holiday in Spain? There's so much I don't know. 
That's why I worked with data. I found it comforting. Reflection provides content and tracks responses during events - talks, meetings, religious services - any gathering. Memory cascades and search trails are monitored and audience displays are engineered to fit the crowd. It's an art. Operators are, literally, right inside people's heads. When universal income came in most people upgraded their medichips with their first extra cash. The government knew they would. Each operator has a multi-layered holoscreen that gives a running commentary on about 100 brains, organised into common themes. An operator has to create a convergence of mood - of shared reactions. The speaker, or performer, or preacher, gives the audience food for thought, and making that into a shared meal was my job. It could be automated, but privacy legislation means you can't run algorithms on biointegrated devices, and anyway, because of all the other stuff in people's heads, final selections couldn't be left to bots. Reflection paid for the service at events, but the company also sells the data we've pulled out of the biospace, and brands can pay us to feature them. When we got it right, people would tell us how the show felt familiar, that it reminded them of who they are. Then there's the vanity angle. Ask a question and you'll get a clip of yourself doing it before you've left the building. It's a good business. The 'youfie moment' was my idea. It's popular. Probably why Jason hadn't fired me already. I loved my work: intense, demanding, but there's a kind of beauty in searching for the threads that will draw strangers together until a community coalesces - however transient. Most people couldn't cope with the control glove. But to me, it was just my cleverest hand.

I counted the accelerating flurry of my steps down each flight. A pause for the jump over the last two, three strides for the landing. I knew I was freaking out when I started counting. I tried to make it into a dua - using the rhythm, praising Allah, thanking Allah, and then I realised I'd left my 
Anodyne ${ }^{\mathrm{TM}}$ at home. I'd already done eighteen sets and with another fifteen to go, heading back was not an option. The truth was that I really didn't want to cover that event, but when I refused the assignment, Jason's hammer of a face made it clear that it was that job or no job at all.

Mrs Gertz's drone followed me for six flights, as usual. It was programmed to do that to all the Muslims in the building. Me and another woman from my floor, Meriam, are starting to sing it cheerful songs and do funny dances - but there simply wasn't time that day, so I carried on getting ready to leave: 'I depart with Allah's name, relying on Him. It is Allah who saves us from sins with His guidance.' One-two-three-four-five. Jump. One two three.

The auditorium was packed: at least 600 people, so there were 6 of us managing output. Jason put me on editorial for two others, but he lead out handing over to me once people settled. Jane Summer was talking about escaping the Twin Towers on 9/11. It's a Wintour Foundation event, marking the centenary of the start of the World War II. The intro about the people Wintour saved from the Nazis made me edgy. No one remembers WWII, but the cant about how everyone worked together is endless. My brother, sister, mother, and I set out from Syria in 2013. We were pulled apart at every stage of the journey and by the time I got to Calais, alone, French police were slashing tents and trampling food. I didn't much like Jane Summer - she wanted us to analyse reactions to see how well she'd do if she started a cult, but you have to admire any 71-year-old who makes such big plans. Her sense of entitlement, was still rock solid, even after everything that happened since temperatures hit the $2 \mathrm{C}$ trigger. 
But I shouldn't have been surprised that a Twin Towers survivor drew such a crowd. Isn't it funny how everyone has gone wild about stories of smashed odds. Whatever we tell ourselves about 1939, only Germany built camps in public parks for people like me in 2015. Praise Allah that they did. With all the disasters that have come since then, 2039 is no better. I always wished we'd aimed for Munich, but only a few years later the cryoclimes sent blizzards of people howling down from the North. Suddenly refugees were all blond. The sea didn't care about the population density of Bangladesh any more than chickens cared about the billion Chinese who died in the flu epidemic.

I shook my head, trying to clear my cascade, and reached for my Anodyne $^{\mathrm{TM}}$ again. Still not there. I thought I'd just about make it through, but it was a nightmare. It's hard to juggle 40 windows with shaking hands, and when my mental flip-book of horror starts running it's incredibly difficult to process even simple data. They've all been there, I told myself. It's 2039: everyone in this room has lost someone or fought for their life. Not lifestyle. Life. One screen told me that 7 members of the crowd were also in a PTSD flashback cascade and the talk hadn't even started. Crowded rooms will do that. Allah keep them laughing. My job sounded creepy to a lot of people - but imagine if the whole room tripped? That'd be a long flight of stairs for a lot of people to tumble down. I could stop that happening.

Five minutes before Jane was due on we started to pull the intro sequence. I was shaking my head in an effort to clear it. Was that an image of Hamburg, flattened, or Aleppo? Those lines of emaciated people - from a German concentration camp or the American corn blight of 2026? Farrokh glanced over to me. He could tell that I was way off my game. He doesn't know 
what happened to me. I don't know what happened to him. Must have been something. Everyone just carries on. He was picking up my slack, but he wanted to know what was going on. I mimed popping a pill, to explain. But he misunderstood me and reached into his bag with a nod. They're not cheap and we aren't paid much. It's not something you can just ask for, but I soared with relief as he handed over the dispenser - then I saw that his dose would barely help me.

Anodyne $^{\mathrm{TM}}$ turned up in the Middle East in 2017. People say it was the UN: chemical warfare with a difference. It became illegal almost immediately, and, of course, terribly popular. It was the ultimate in haram. But Anodyne ${ }^{\mathrm{TM}}$ worked. People walked away from their righteous fury, swallowed their pasts, found the strength to leave mourning, leave expectations, were able to live with loss, and terror, and trauma. Taking a pill is like having the sun rise inside you. Israeli settlers moved out without kicking up a fuss. The Saudis stopped killing and torturing. Now, of course, Anodyne $^{\mathrm{TM}}$ is sold along with cigarettes. People have to stop taking it if they want to get pregnant, but then they land back in reality and change their minds about having kids. I was first given it by a tired GP in Wales.

I took a deep breath and blanked all the screens; I clamped my hands together to stop them from shaking. She was due in 30 seconds.

Seeing Jane Summer in real life was a shock after all her strident emails. She shuffled along the stage with her Zimmer frame, but it was such a jaunty shuffle, I had to wonder if the zimmer wasn't just a prop. She wore a very sharp, plumb-coloured suit. From her starched, white, throat, came an incredibly powerful voice. 
"My day started like any other; coffee and a commute." Image: a steaming coffee cup. The audience sighed at the thought of coffee. Data: link to regions free of root worm, where prisoners pollinate the bushes by hand. There's a black marketeer in the audience. I sent that link to her private phone.

"I didn't know it, but I had woken up as someone's target." Jane's indignation was still hot and the ageing crowd loved it. They're sick of being cowed by their children. These changes were meant to happen to descendants they'd never meet. How can everyone be pointing the finger at them? 'Everyone had cars back then', they'll say.

"There was an odd, dull thud." She delivers this with such a gust of doom it made me angry. There were no children in her ivory towers. There were no state-sanctioned actions: rooms of respectable men calling their decision to bomb responsible or necessary. When I was a kid they were firing mortars at us and the UN were ok with that. I remember how incredulous my fellow refugees were when the UK voted to bomb Syria. Suddenly I could hear it all over again. Like vast, dusty dominos, the buildings heaved off the vertical, ripping. Thump thump thump. The door sounded hollow. The men who barged in and pushed my mother aside smelled clean. My father stared at us, imprinting our faces, and was gone.

"I was with a group trying to get to stairwell $C$, when a slab of concrete I was standing on started to slip. I told my dad that summer surfing wasn't wasted!" She was crowing, swinging her hips and riding that Zimmer-frame surf board like a pro. The audience loved it. They were all flashing on beach picnics and surfers and swimming pools. They needed flipping from doom to triumph. She was good. I had projected a surfer over the shattered rubble on the screen when a gasp makes me look up. Asma, Alvand, and my own child self were squinting at the audience. Mother was staring right down at me, smiling her encouragement, willing me to get 
through it. The crowd saw a threatening Arab man and veiled women - fear flashed through them. They went: suicide vest, loved one, escape-route, who's blocking my path? I knew this would cost me my job. The image came off, and I pretended to work, but I could hardly breathe for wanting to scream at these idiots. "You didn't know them!"

"Anyway," said Jane, with a little cough. "Flashes of normality kept us going. We were powered by civility. We just had to keep on tramping down. I'm glad we had no idea the building was less than an hour from collapse." My throat closed, and the memory of unbreathable dust almost made me choke. Alvand said that not even he could have grabbed the little one. His face was white with powdered concrete, apart from two clean lines tracking down from his eyes. I don't think he even knew he was crying.

Powered by civility? Ignorant of desperation would be more accurate. My brother had been taken by people who paid the traffickers for recruits. If he didn't go and fight, then we'd never make it to Greece, they said.

"There was an incredible solidarity among the New Yorkers who didn't abandon the city. Leadership qualities emerged and people formed supportive communities based on shared values." I completely gave up trying to work after she said that. On the boat from Turkey to Greece, we knew what was happening. No 'leadership qualities' emerged as people were trodden into the gathering water or pushed over the side. I figured that since I was going to lose my job, I might as well really lose it. Gulping for air I flashed up a notice that read: 'DOESN'T SHE KNOW THAT LEAVING IS NOT ALWAYS A CHOICE?' Jane Summer had never stopped to think that for literally millions of people it's 9/11 every 
single day! The shocked pause that came after my notice was broken by a finder alarm, a rising sound that demands attention, something between joy and a shriek.

The paramedic had seen so many cases like mine, she could tell I was having a reality crash from across the room. She's forbidden from giving out pills. Health officials have to swear that they will always make people pay for meds. "Just breathe", she crooned. The medidrone hovered above, recording what she did with me, announcing her name, Luci, and my medical code, for its own black box. Luci handed me a paper bag. "Nice and slow." She rattled it slightly and touched her pocket, subtly showing me that she has some pills on her, that there was one in the bag. What a lawbreaking treasure. She must have put the Anodyne ${ }^{\mathrm{TM}}$ in there before she crossed the room. I practically grabbed it out of her hand. I noticed that she was missing two fingers. She shrugged. "It was worth it," she said, and I wondered what the circumstances were - I bet she lost them trying to save someone, or maybe her own hand. Luci's pills weren't quite strong enough, but I improved with every second. I thanked her and we shared a moment. I pushed my self-pity aside because I am one of the lucky ones.

I'm lucky because back in 2015, Isam and Ewan were stuck in traffic outside the ferry port and they actually saw me. Not a veiled woman, but a terrified girl. Men were trying to pull me towards a van. They were strong, but I fought them because I had recognised the looks on their faces: hungry and smug at the same time. After the buses across desert, even salt water was liquid joy. Suddenly the brutes who had corralled us from one vehicle to the next were just young men body-surfing, looking at us shyly from the corner of their eyes. Mother called us away from the beach. We were vulnerable without my brother's protection. The next day mum begged for 
mercy, but they roped you like a reluctant calf and dragged you away. Isam overheard them saying unspeakable things. He said he didn't know that he was going grab me until after he'd done it. He charged into them headfirst, tucked me to his chest like a rugby ball, and scrummed us back into the car. Then we were off, heading down the hard shoulder, past distressed policeman and dogs distracted by a freezer van. They got me western clothes and a new passport within hours. There were advantages to being half Welsh, he used to say, but getting me out of that scrum was the best of them. These generous, clever, brave men became my parents - my two fathers, who loved me, and looked out for me and gave me a new life. They made me keep up my studies - kept me speaking Arabic, even though Ewan couldn't understand. They encouraged me to continue my faith, and the connection to my past, and future, and the solace that it gave me, even though it had rejected them. They taught me to always be proud of who I am. Isam is a lawyer. He said the officials were too scared of challenging the adoption rights of a gay couple to make a fuss about my citizenship.

“'Nother one?" The paramedic was leaning close. I nodded, just a touch, hoping that the drone hadn't heard us. The finder alarm was getting lounder. Drones were flocking round our part of the room. She was taking a massive risk, so she slipped away.

Jane's voice rang out clearly: "I know you are also hurting, and I know you all have stories too, but we can work together. 9/11 woke me up to that power. Say it with me now: Calm and kind will change everything." The whole room followed her, including me. Calm and kind will change everything. I seriously hoped so, because that was when I noticed Jason, striding towards me, looking like the anvil this time. Luci was coming back too, bringing a glass of water. My boss nearly shoved her aside, but deferred to the uniform. I offered him the water and he took it - 
eyeing me and gulping while behind him Luci signalled that there was a pill in it. Behind her the drone started flashing. It called my number. And I thought... I'm going to be arrested for spiking Jason's drink. But instead, there was a sound of celebratory bells ringing. The sound they make when a Finding is confirmed.

"Connection. Links to our database have located a picture match. Esma. Sister. Belgium.”

I couldn't believe it. After all the searching, I'd done. Esma, my lovely sister, you were always there to catch me. The crowd didn't know what to do with itself. Half were clapping, half were still waiting to see if I'd be arrested.

The hospital has explained that you haven't spoken for many years, and I don't expect you to come right out and talk to me, but I'll keep sending you these messages, and when I visit, we can just sit together, if that's what you'd like, in front of the opened door. O Allah, the One who returns the lost, by Your power and awe You returned what I had lost, for surely I have received it as Your gift and favour.

I love you Esma.

Zeinab 


\section{The Day No One Died Gwen Bellinger}

Author Bio: Gwen Bellinger is a writer and consultant currently working with the Indian government's Department of Education. In 2015, she completed her M.A. in Middle Eastern Studies from the University of Chicago, focusing on Islamic finance, the Gulf aviation industry, and Arabic. She has experience writing for travel companies, English language courses, and academically in the fields of economics and history. Originally from North Carolina, Gwen obtained a B.A. in History from the University of North Carolina- Chapel Hill in 2012.

The asphalt burned Asiya's feet as she hurried down old Al Obour. Beads of sweat formed on her brow. She inhaled the thick of July, his face flashing in her mind. Pallid, dejected, dead. Her basement floor clinging to her memory like a tick, sucking out her life force, leaving her infected. The strange man's black hair matted to his forehead, his naked body twisted at the bottom of her stairs, a lifeless eye burgeoning from the middle of his chest. That same grotesque eye seen everywhere on the streets of Old Cairo, a mark of wealth, a mark of evolution's chosen race, a mark of the high cost of her crime.

Fireworks burst overhead illuminating a mountain of empty bottles and trash remaining from the evening's annual "The Day that No One Died" Festival. To her right she saw the remnants of a Neostarlite party on the street. Teenagers. Unaware that the holiday had finished hours ago .Most of their race slept soundly. The naked girls waltzed with the beat of drums, trace-like, painted red with beads strung in 
their hair, the latest trend on New Earth. The gruesome eyes on their chests outlined in black and decorated with scintillating stones and glittering powder. Optimal foreign beauty at it's height: a large, ostentatious chest eye. The men belted along to this year's top songs, imported from their home planet and broadcasted for ex-patriots. A cacophony of drums, sitars, and chanting of young men blared from the street. The sound of home for a new age of colonization. The sound of wealth and privilege for a new age of the racially repressed. The haveeyes and the have-eye-nots.

One of them swayed back and forth, unable to hold himself upright from the elixir of bhang and milk, imported from the Himalayas, a favorite of the privileged Neostarlite race who had become too accustomed to their own drugs and preferred the medications of the Old World. An old remedy for their new problems. Too much money. Too much beauty. Too much freedom. Unaware of the religious history of the plant. Of Shiva. Of Hinduism. Only the high of the Neostarlites mattered now.

"Hey!" One of them called after Asiya. She slowed from a run to a trot. "So many clothes," he called in a sing-song tone over the noise of the music. "You should try going au nat-tur-elle like these lovely Neo creatures." Asiya watched the young man wrap his arm around one of the giggling naked girls and lick her neck.

"Rohonon," the girl whined, "You know the Natives only cover up because they are embarrassed they don't have third eyes." She spoke in Neo, mostly likely assuming that Asiya wouldn't be educated enough to understand the language. A fair conclusion statistically. An incorrect one all the same. 
"Nativegirl sare hot, I wish theyd stop wearin ethniclothes and just wear nuuuu-wearth trendssss," he slurred as he buried his face in the girls' hair.

She eyed Asiya jealously at the comment. Asiya rolled her eyes and walked by the group of Neostarlites without speaking. "Cyclops..." She swore under her breath.

The Neostarlite party distracted her, momentarily relieving her of fear's fierce choking at her lungs, guilt's subtle whisper in her ear. But the tick took another bite and she recollected the jagged scream that escaped his body as it bounced like a toy down the bricks, the black syrup of blood spilling on the cement ground around what used to be a head. She cringed.

Asiya knocked at Jusanon's door. Black mascara dripped into her eyes, salt from her sweat tasted pungent as it leaked into the sides of her mouth. She knocked again, left alone with only the sound of cackling Neostarlite teenagers and her own panting. And the haunting thunk! of a Neostarlite dying in her basement replaying over and over in her head. With that one sound a man could be brought from monarch to meat, with no afterlife subscription to carry any remaining soul out of his lifeless body. Resentment shed its armor leaving pity for the entire race of the Godless. Once human, turned Neostarlite, enlightened in their lack of faith, alone in an expanding universe.

The door swung open. Jusanon stood in the frame of light, tall, broad, confident. A savoir, if she could help God plan her fate. His body naked and blued from paint. The black circle around the ugly little eye on his chest. Large, half-open, a sign of manliness. His face appeared startled when he saw Asiya standing there. He looked down at his body and back to her shyly. 
"A-non," he cried, "I-I wasn't expecting you." He opened the door to let her in but was more preoccupied with shuffling into his bedroom and rummaging around for clothing as he called to her, "I thought you would be celebrating Eid with your friends, A-non." A few shirts flew by the door frame. "Why are you out on 'The Day that No One Died?'” He pulled pants over his bare leg. "You know its not a safe time for Natives." Shirt, shirt, shoe, shorts.

He reappeared in jeans and a white shirt which he buttoned as he walked out of his bedroom. His chest still blue with dried pant. He noticed her staring at the third eye on his chest and his cheeks flushed.

"Sorry," he murmured, quickly finishing the top button, the fabric walling the genetic license from sight.

"Don't apologize," Asiya said flatly. "It's who you are." After all, that one genetic modification could be the difference between life and.....the alternative. That eye brought Jusanon power. Power she never had. Power the body in her basement used to have. Maybe Jusanon could help her, save her. An eye for an eye.

"So....is everything okay? You look frazzled." His black eyes (the two normal, human-looking ones) watched her so prudently she had to look away. His apartment walls seemed to measure their relationship in favors for her. When he got her admitted into Diagoras of Melos Medical center, a hospital almost exclusively reserved for Neostarlites due to their more complicated medical needs. When the police found her ragged copy of a Qur'an and he argued that it was part of his journalistic assignment. When he offered to sponsor a visa to New Earth for her, where she could pursue a degree in museum studies. When he offered to call his uncle at the University of New New York and arrange a trainee position in the museum of ancient religion and antiquities. 
When a Neostarlite fell down her stairs...

Because even Allah knows a Native will never win a case against a dead Cyclops in a basement full of banned religious books.

She met Jusanon two years ago at the Neo Institute for Language and Native Advancement. New Earth immigration requires $80 \%$ fluency in Neo, two official courses in New Earth History and Society, and a course in New Earth Politics for a student visa. Her restaurant, The Pyramid, was nearly three years old at that point, a success amongst Neostarlite ex-patriots living in Cairo for their aid work. She was able to charge four times what a Native restaurant might charge. Her success earned her the ability to pay for the classes. At the time, she was still hoping for a scholarship on New Earth.

In history class that morning she hadn't even seen him walk in. It was the day after "The Day that No One Died," two years prior to the clunk of a man dying her in house, and she could overhear two of the teachers in the break room grumbling.

"I can't believe we have to work today!" she heard in Neo. She leaned forward in her chair to see two aid workers slouching in the break room across the hall. One of them had pulled her t-shirt up to her breasts and fanned herself with a stack of papers. "It's the day after 'The Day That No One Died,' we should be hung over in our beds," she complained, rolling her eyes. "I wish these Natives would celebrate, too, I don't understand why they don't."

"I don't think it's in their culture," a male aid worker was saying. "They still celebrate the day their big nuclear war ended back in year 50 or something." 
"It's funny, don't you think?" She was responding. "They celebrate the end of one war but why that war? There were so many here. And yet, they refuse to celebrate the end of all wars, the first peaceful revolution in the history of Old Earth. I don't get these people."

"That's why we come here and teach them how to be civilized!" The male said jokingly. "At the expense of our hang overs! It's the burden of the Neostarlite, spreading the knowledge of our enlightenment."

"Oh shut up! You just teach beginner Neo, that's easy!" She pushed him jokingly.

"Yeah, I'll pack up and return to New Earth if I have to teach 'the dangers of religious thought,"' he concluded.

"Aay-zee-yuh?" Asiya jerked her head around at the sound of her name sticking to her teacher's tongue. "Can you tell me the top three reasons that the Neostarlites left Old Earth and colonized New Earth?" She was asking. She wore a little black dress instead of going nude like most Cyclops. The Institute mandated a uniform for all aid workers as a way to respect the culture of Old Earth. The workers loved to complain about that.

"They left when the third nuke dropped," she said, tiredly. Asiya had learned Neo history in her private Neostarlite school days. The only Native in Old Cairo to receive a scholarship to a Cyclops school. Her grandmother had been so proud, telling everyone on the street that Asiya would receive a Neostarlite education and obviously that would allow her to one day immigrate to New Earth. Now the textbook was regurgitated from a blonde aid worker covering her third eye with black traditional clothes which she wore backward and tugged at 
uncomfortably.

The aid worker nodded, "and what year was the third nuke dropped?" Before Asiya could respond a young girl in the back piped up enthusiastically, "Two thousand fifty!"

Asiya cringed at the use of the Gregorian calendar. 2050? That's exactly the kind of answer they are taught to stomp out of us, she thought. That's the type of answer that makes them think we are all uncultured space debris. She turned her head in her seat to look at the girl who hadn't yet realized her mistake.

That's when she saw him. Sitting in the back of the room, his head turned in the direction of the girl, his kind eyes nodding her on respectfully, as if rooting for her to continue with her answer. At first she assumed he was Native. A very tall, very handsome Native. But definitely Native. Why on New Earth would a Cyclops be sitting in a visa prerequisite class? But his eyes, they were so black. Almost metallic. Mesmerizing. The type of enticing that only comes from those born beyond the Milky Way, bred for centuries in an atmosphere plump with healing elements in the air and strengthening agents in the water. They lived longer, they grew taller, they advanced (as they told the story). They mutated (as others told it).

A collection of illegal books decorating her basement, Asiya had read every version of history she could find. The reasons for the Great Nuclear War told by historians hundreds of years before anyone knew the Neostarlites even existed. Alternative textbooks written by "radical" scientists and historians. Some even written by Neostarlites who had visited Old Earth in their youth and challenged the government-issued books. Years and years she read the required history textbooks given to her at her Neostarlite school. Always from their perspective. Always 
leaving out the developments that took place in the1000 years they had left Earth. Nothing about the two hundred years of peace. Nothing about Japan sinking into the sea. Nothing about the US refugees fleeing to South America after the great nuclear disaster of 2573. Nothing about religious festivals, of religious governments, of Muhammad, of Jesus, of Moses. Nothing. She found manuscripts from before the return, from before 'The Day That No One Died.' She educated herself on a secret history, one cast off by the Neostarlites for a posher, more adventurous history of new planets, space travel, and new scientific discoveries. An interesting history that cut off its roots. That had forsaken its creator and its witnesses.

The teacher distributed a pop quiz. Asiya knew the answers. She also knew the "correct" answers. How can we translate the past? Let me count the ways.

\section{1) The Neostarlite race originated on the planet Old Earth.} When did they leave? List three reasons why they left:

a. Correct Answer: The Neostarlites left Old Earth in the year 0 because the United States of America dropped a nuclear weapon on Canada due to religious differences. They left in order to 1) safeguard humanity from impending nuclear destruction, 2) they wanted to establish a new way of living without war and religion, and 3) they wanted to eventually reeducate the survivors of old Earth in enlightenment and peace.

b. Alternative history: The United States accidentally dropped a nuclear weapon in Canada prompting a 
retaliation from other countries due to their negligence. Some earthlings were afraid of dying so they left because they had the money to leave. It was in the year 2050 according to the widely used Gregorian Calendar of the time. They had no plans to return.

2) After the nuclear attack, a world war raged for centuries. Why?

a. Correct Answer: Religion

b. Translation: People from a variety of socioeconomic, religious, cultural, and linguistic backgrounds fought off an on for a variety of reasons. The "war" wasn't one war yet a serious of smaller wars and battles fought over hundreds of years for a variety of reasons. Most of the time was peaceful.

\section{3) Why did the Neostarlites resettle Old Earth?}

a. Correct Answer: Neostarlites are enlightened. They need to save Old Earth from violence. It is their duty to education the less fortunate in ways of peace and anti-religion (the bringer of violence).

b. Translation: Money? Power? Guilt? Boredom? Curiosity? Maybe they do want to spread enlightenment but are Neostarlites actually happier? (Asiya hasn't found a clear answer on this in her books)

4) What is The Day That No One Died and why is it celebrated today? 
a. Correct Answer: The day that the Neostarlites returned to earth, 1050 years after their departure. It is the day they reclaimed Old Earth and brought peace. It is the day religion became outlawed. The first day of true peace on Old Earth. The Natives welcomed them with open arms.

b. Translation: The Neostarlites returned in the year 3100 according to the Gregorian calendar. Why? Resources and labor. Did Natives welcome them with open arms? It's unclear from the reading. Maybe some. Others not. New Earth offered all kinds of new technology and after the breakdown of world government in 3076 (1026 in the Neo calendar), no one was much prepared to fight the Neostarlites.

\section{5) What are the advantages of resettlement?}

a. Correct Answer: The removal of religion to bring peace, and the knowledge the aid workers can bring for enlightenment and a better life for Natives.

b. Translation: Money pouring into the restaurant.

"Why were you sitting in on our class today?" Asiya asked the strange man with black eyes after she turned in the "correct" answers to her quiz. He was standing in the hallway of the Neostarlite institute looking down at some sort of red device she typically saw Cyclopses with. His blue pinstripe button down shirt covered his third eye. But seeing how tall and broad he stood, she felt silly for mistaking him for a Native earlier.

"I'm a reporter. I'm doing a story on the visa process for 
Natives," he said slowly.

"You should do a story on me, then!" She said confidently. The dazed look on his face indicated he didn't know Native girls weren't as shy as the media typically depicted them.

"I'm Asiya, I'll be your correspondent," she said, sticking out her arm and putting it over his chest in the formal Neostarlite gesture for greetings. He looked down at her hand touching his chest as if he was frightened she would set him on fire.

"Your Neo.... It's fantastic," He stuttered "Better than the Natives I know on New Earth," he continued.

"I went to an all Neostarlite private school," she said proudly. "I got the only scholarship in Old Cairo. I'm very smart." She beamed. He smiled back slightly but his shoulder still remained broad and stiff.

"So, don't you want to interview me? I'll make a great story."

She made a fantastic story. Six weeks later she received a letter from the Department of Neostarlite Immigration that her visa had been rejected. A few days before her application, a Native who had been born in Old Cairo (but who grew up in Old Boston) had set fire to the Department of Religious Destruction. A radical Christian. The first attack in decades. All visas from the two cities were rejected until further notice in order to decrease the level of religious violence on New Earth. Great for Jusanon's reporting career. Bad for Asiya's future.

Jusanon received an invitation from the New New York Times offering him a full-time position. He could return to New Earth as an intern in the headquarter office helping to cover stories about new trade routes established between the planet's capital, Soulfour, and one of its newly colonized moons. He turned down the position and instead 
he pitched a story to the Soulfour Third Eye about Native fashion, asking them to fund an extended stay in New Cairo. They declined but he stayed to write the story anyway. It took another month for Asiya to realize he wasn't nearly as interested in the story as he was in her.

The sun had risen by the time they reached her apartment, far from the posh Neo areas. Jusanon came up from the basement, black eyes dull, face white.

"So, you can call the police and your lawyer friend?" She asked hopefully. "As long as you are here, they should believe me, right?

Jusanon rubbed his two human eyes. Then his one Neostarlite eye. Asiya also rubbed her human eyes, tired from the long Eid celebration, the excitement of the break-in, the many hours of being awake. She didn't have a third eye to rub so she rubbed her left eye a second time.

He was sitting next to her, shaking his head. "This is really bad, A-non," he was saying, "this is really, really bad."

"Just call your lawyer friend. Have him come here before the police. I'll pay whatever I have- “

"It won't be enough, A-non," he said, still shaking his head.

"I'll pay you back, please, Jus. I'll pay you..."

"It's not the money. He wouldn't even charge me. You can't win this case, A-non. Hundreds of illegal books in your basement? Multiple copies of the Qur'an. You're a religious zealot, A-non."

"I'm NOT," she said defiantly. "I would never hurt- "

"I know, A-non," he cut her off, "I know...But they don't." He motioned his hand toward the door. "They are terrified of you people. 
You think they will let you go for an accident after they see your library? All they want is to make an example of the religious, whatever is left of you and....you're a prime target....they'll use you to scare whoever is left of you people."

Her heart began scrambling around in her chest, looking for an area with more oxygen. Or looking for an abort button. Why had the Neostarlites developed a pill for daily hygiene and not for time travel? Awkward silence slouched between the condemned couple.

"We can move it!" She said excitedly after some time.

"Move it?" Jusanon inquired.

“The library! We'll get some boxes; we will move it to Ahmed's house. He'll be happy to take it, it- “

“That will take days. You think the police won't realize the body is a few days old? They'll even know it's a few hours old at this point!"

"No, no no no, Jus, we'll move the books, it's okay, it has to be okay," she felt her fingertips going numb and the burn in her throat as her distress began to leak from her eyes. There had to be some solution.

"We'll have to hide the body," Jusanon said quietly. "We'll hide the body. And then we'll leave. And by the time anyone discovers it, we'll be gone."

“Wouldn't you prefer going out with your own kind?" Asiya had flirted, a few months after first meeting Jusanon. He had stayed in her restaurant all day, chatting with reporters on New Earth and about the different angles he could take for his story and setting up interviews with Natives and ex-patriot aid workers about perspectives regarding fashion. He spent most of his time writing in her restaurant, telling her 
it was because she had a chic place, akin to what he was used to on New Earth, and with one of the best direct calling beams to New Earth he had seen in Cairo. He played with the little red device.

Days turned into weeks and the entire kitchen staff had noticed the way his black eyes became almost blue whenever talking to Asiya. They way he dressed up in formal Native outfits unlike the other Neostarlites who simply walked around the restaurant nude. The way his cheeks dimpled when she spoke to him. That he always managed to need to stay until she closed.

One this particular night, he once again stayed past closing. He proposed they start seeing each other more, maybe taking a weekend trip to Old Dubai to see the ruins of the Burj Khalifa, the tallest building in the world at the time of the Neostarlite exodus. The stacks of rubble a tourist attraction to Natives and Cyclopses alike.

"You are so much more interesting than Neo girls, A-non. Seriously. I love hanging out with you. That story on your visa was so much fun. Learning about your education, your obsession with antiques, how you can understand your own history from so many different angles. What can I get from these girls who just get drunk and talk about teaching Neo like it's some sort of sainthood?" He rolled his eyes. "Come on, no obligations. Just let's hang out more."

"I'm not sure. It might be difficult for you, dating a Native." She said. He told her how many people he knew dating Native girls. How many Native immigrants moved to New New York every year. "There were Natives from all over Old Earth in my school,' he had told her. 'I won't expect you to go to bhang parties and stop dressing in public or anything." He looked like a child, his black eyes dazzling, wide. She thought of the Native girls who walked around naked, painting third 
eyes onto their chests, speaking broken Neo. Natives marrying Neostarlites for visas. Neostarlites marrying Natives and bringing home exotic souvenirs as wives. Except it isn't marriage on New Earth. That's just for Natives, a leftover tradition from times of the violent religious dark age. Now its just joint-rational agreements. She didn't know how to tell him, "Yeah, but I'm Muslim and I'm not sure you'll be okay with that." If she told him and he reported her....

One member in her religious circle was reported five years before. He cut off contact with everyone immediately, not wanting to put their identities at risk as well. Rumor circulated that the police questioned him for hours. He denied his faith over and over but it wasn't enough. 'He's still monitored,' the elders say. 'If he so much as opens a Qur'an they'll throw him in jail.' The group tried to contact him, tried to help him in his time of need, but after some time he fled. Last they heard he had been forcibly converted to atheism and rational thought, too afraid to show any outward religious action.

Three days after she declined Jusanon she developed Tykota, a virus originating on New Earth and breaking out in crowded communities hosting Neostarlites. The virus barely gave the new race a runny nose. Their immune systems had adapted hundreds of years ago. Yet thousands of Natives died every year, their immune systems were not yet enlightened.

After three days of violent vomiting and uncontrollable shaking, she called Jusanon, hoping he could have her admitted into a private Neo hospital, renowned for their superior medicines and better trained doctors. Private doctors were a commodity. Often Natives were dumped with ill-trained aid-workers who offered free health care. Unlicensed to practice on New Earth, the poor health conditions, lack of medical staff, 
and low salaries on Old Earth offered a great practice arena before the trainees became real doctors needing to treat Neostarlites back home. A convenient warm-up before the main event. Native lab rats.

Asiya was admitted. Jusanon returned to her home. And that's when his snooping led to the prize treasure hunt find of a bookshelf in her basement full of old manuscripts from before "The Day That No One Died," Qur'ans, Islamic art, alternative textbooks from radical Neostarlite writers. Enough material to have her arrested quicker than he could have her medically treated. Quicker than you could say, "A Native damned."

A few weeks into Asiya's recovery Jusanon still visited regularly in order to see to it she was well-hydrated. She mostly complained that the illness was going to hurt management at the restaurant and asked him to check in with the staff to ensure the kitchen remained stocked and customers were seen to. She was rambling about her certainty that they would surely run out of imported johnnyfruit, when Jusanon interrupted her, the words bursting out of his lips in double speed, as if they had been knocking around his brain for days trying to find an escape.

"Why are there a bunch of Qur'ans in your basement?" He had asked.

The question she had been preparing for every since her grandmother died. The question she had been primed for for years. ' $O h$ yes, I can't even read Arabic, she should say, I kept them because I am interested in antiquities. I am hoping to have them sold to the museum of New New York's history of religion collection.' Followed by an academic rambling of the importance of realizing humanity's dark period before enlightenment. 
But anytime Jusanon looked her in the eyes she became lost in the blackness of his. She was sick of hiding and lying. Sick of pretending for years to Neostarlites that she fit their perfect imagine as an enlightened, atheistic Native. An example of what stomping out religion could be. Because the first time her grandmother told her the magical stories of the Arch and Allah's rain, she felt inspired. The first time she heard of the Kaaba, rumored to still be controlled in the desert by surviving Islamic tribes, she longed to travel East in search of the mysterious place. The first time she heard of Joseph's rise from slavery to finance minister of Egypt she vowed to rise from a poor Native to an influential Egyptian. She felt apart of something greater. She felt everything fit together for something better. She stroked those fables as a child, smug that her stories were older and purer than the stories of the first Neostarlite colonists that the other children told. Hers were sacred, secret, special. And she held onto those millennial-old stories when the Neostarlites told her of the great darkness unfolding at the end of their rational, meaningless lives. She clung to them when her grandmother succumbed to Tykota and the aid-worker told her, "she's gone." Because Asiya knew her grandmother wasn't really gone. And that that everyone was a small speck in something greater. And she was sick of hiding that inspiration. So she tossed aside the advice her grandmother had given her about defending the books and she simply told Jusanon, "I'm Muslim."

He didn't say anything for awhile. So finally she asked, "Are you going to turn me in?"

He shook his head. "Teach me," he said. 
"You should be fine," Jusanon was saying, "as long as I come with you. You have a DEP class visa" he pointed to a mark on her arm where her visa information had been tattooed on, "which means you are free to live and work in the country as long as your sponsor is with you. I know we were hoping to wait and get it changed to an IND visa but we can try from New Earth."

“I can't even leave the house without you. What kind of life is that?" she spat, defiantly.

"A-non, please....its the safest option for us right now. It's the visa you have, we can get it changed once you are on New Earth. If we get a joint-rational agreement, we can get it updated in a few months...." Asiya rolled her eyes and sighed.

“A-non, there's a body in your basement, we don't really have time to complain." His logic burned into her mind. So this is how her future unravels? An escape to New Earth, spending her time inside his parents' house while he works until they can get her visa sorted. Wasn't she meant for something bigger than to be somebody's wife? Would she meet any communities of religious followers? Is that even possible with a DEP visa? She couldn't even go to the market alone. And even if she gets an IND, the punishment for religious activity is stricter on New Earth than Old Earth. Then again, she'd be in a joint-rational agreement with a Neostarlite, what Cyclops would ever suspect? Is this the last Eid I will ever celebrate? She wondered, thinking of the man chasing her to the stairs, the sound of his head bouncing on the concrete, the shriek. The silence.

"Why do we have to leave?" She moaned.

"The technology used to match DNA only works in a radius of a few hundred kilometers. Even if they find your DNA on the body, if you 
are on New Earth, they won't find a match." He always exuded such confidence.

"And? Just abandoning my apartment? My restaurant?"

"It's worth your life?" He sounded exasperated.

"No, but isn't this a bit....I don't know, a bit suspicious?"

"We are entering into a rational-agreement, A-non! We are going on honeymoon, meeting my family. It's a perfectly good excuse."

"So, what do you want to do with the body?" Asiya puzzled.

"I have a plan." Jusanon retorted confidently.

"And? Do tell?"

"Before I met you I did a report on the morgue in Old Cairo. It's chaos in there. If I leave the body in the waiting pit, the cremation staff will just assume it is untagged. It will take weeks to sort out if the body belongs to a family or not."

"But the body does belong to a family, Jusanon!" Asiya cried. This is someone's family.

He stared at her blankly.

"It's not right, Jus. To just leave the body. I need to turn myself in."

"Is it right for you to be executed for a crime that you didn't even commit?" He snapped.

"No, but-"

“They'll come after your religious circle, you do know that, right?" His voice became quick, forceful. Jusanon had a point. "They'll come after all the Muslims. They'll twist your story," he argued.

She didn't want the remnants of Islam to suffer because of her... 
So she packed. Two bags. Two bags for everything she owned. Two bags, no Qur'an. She stared at the ragged little book. The book she slept with every night after her grandmother died. The book she leafed through trying to make sense of her lack of family, her position in this society. The book that she brought to her community of worshippers when she didn't find the answers herself. Only in museums did this book exist on New Earth. She imagined a little white button next to the item, the steady, cool voice in Neo saying,

The Qur'an, copy circa year 1,030, based on the original compiled in the year 1,416 B.N. (644 according to the ancient Gregorian calendar). The book was considered the Holy word by the Muslim religious community, reaching its height at 2 billion adherents before the great war in year 0. At the time, this constituted about 25\% of the Old Earth population. Under the new Neostarlite satellite government set up in the year 1050, all Muslims converted to atheism and rationality.

She imagined her child learning these values on school field trips and history class, unable to leaf through her own copy. Unable to learn Arabic in the strict world of New Earth. Being born with a deformed eye on her little theoretical body, marking the child as superior to the womb whom birthed her. Basking in the privilege brought about by living on New Earth, resenting the useless vessel that gave her life due to Asiya's shameful Old Earth background. And for a moment she feared and despised her hypothetical offspring.

What would her circle of believers think upon her departure? Pride for one of their own making a better life for herself? Anger for leaving without saying goodbye? Understanding? Suspicion? Resentment for her abandonment? Judgment for trading her community and her faith for material wealth and Neostarlite-style 
education? Hope that she can spread Islamic teachings to the new planet?

She thought of them. Ahmed, in his late 60s. His parents jailed before dying from a tykota outbreak in the cramped corridors that housed religious zealots. Orphaned at 14 , he forgave the Neostarlites from their transgressions, praying that they one day would understand true peace; that the Neostarlite people were suffering without Allah, trying to find enlightenment in wealth rather than God.

Amr, who so loved his wife and baby. His parents lived in a very small village a few hours from Cairo. Typically, they visited the village for holidays. He told stories about how freely people could celebrate in the rural areas. No police or Neostarlites bothered patrolling in the desert. Poor but free.

Leila, born in Old Cairo to a wealthy Muslim family that moved to New Earth in her childhood. She returned after she saw her parents struggled to practice their faith. She worked directly with the Neostarlite government in order to improve Native-Neostarlite relations. They all had big hopes for Leila and knew one day she would help relax the stringent anti-religious laws.

David, originally from Old London, and the only non-Muslim in their group. He came from a family of Christians and moved to Old Cairo in order to pursue a degree in Neo and education technology. Unable to find any Christian believers in Cairo, he joined Asiya's circle. They enjoyed his company, comparing and contrasting the tenants of the religions. They gained a stronger idea of their joint history and culture and celebrated new holidays like Christmas.

She thought Femi who became a second grandmother to her. Who ate at the restaurant almost everyday loyally, who consoled her 
after her own grandmother passed and was always there for advice and emotional support.

They would be hurt if she left them suddenly, but they wouldn't be angry with her. That made me her even more sad to leave them. It made her even more sad to think that her child would never meet them and see the kindness and support a religious group could provide. Maybe she could find one in New New York? Or maybe she would die, an unknown Muslim, on an entire planet without Allah.

Her restaurant had stayed open late that night to accommodate for the Eid celebration. Coincidently, this year Eid shared its celebration with "The Day That No One Died." Asiya pretended the fireworks were for them. Bowls of hummus, marinated goat, succulent chicken, fresh vegetables. This is the food our ancestors have been eating for hundreds of years, her grandmother had once reminded her. Be thankful you can still celebrate this day. One hundred years after The Day That No One Died, no one remembered much about Ramadan or Eid anymore. Religion was no longer associated with celebrations. Only radials and violence. Asiya's grandmother thanked God for this. Nowadays, as long as you weren't caught with a Qur'an, or any religious text, you remained safe. It wasn't like that when I was a girl. People were terrified. Now people were forgetting about religion. Asiya wasn't sure if that was something God would want to be thanked for. But she appreciated it to the alternative. To the terror in the early years of the Neostarlite resettlement. To the police raids and fear and executions. Now, just keep your head down, and don't get caught. 
Asiya and her small circle of worshippers gave thanks that they could continue an ancient tradition in the quiet in her restaurant. They gave thanks for their food, their friendship, their faith. They took turns reading from the Quran; Asiya read them stories from her books about families celebrating Eid for the last thousand years, how the entire city participated. She told them about Old Dubai wrapping restaurants in black curtains to help Muslims avoid temptation, about fining anyone caught smoking or eating outside. She told them of the sweets consumed in Egypt, of the meats across the Levant. Even in times of war, the book discussed ancient refugee Syrians celebrating Eid in their displacement camps, young boys banging pots instead of drums. They prayed the stories were true, despite their doubts Islam ever existed in public life.

The group ignored the chaotic streets outside. Police became lax on The Day That No One Died. Neostarlites ran through the streets painted red and green, shouting and running with their flags. They set up speakers on the street and let their naked bodies sway to music from their home planet. They drank alcohol, they consumed bhang, they worshipped their intoxication. They prayed to no one for their success. They made a religion out of their lack of religion.

Native girls are never recommended to walk alone on The Day That No One Died. Ahmed helped her clean up and demanded to walk her in the opposite direction home but Asiya continued to decline. After an hour of cleaning, Ahmed protesting her independent decision on the couch, he finally fell asleep. He accidentally slept in the restaurant anytime the group met. It was a safer area than his apartment, so no one ever woke him. 
It wasn't until thirty minutes into the walk that she felt strange. She stopped on the empty street abruptly and heard a slight tapping sound of feet halting suddenly. She began walking again and stopped after only a few seconds, again listening to the stumbling sound of feet. She pretended to rummage through her wallet, turning her body slightly in order to glance behind her. Out of the corner of her eye she saw only the vacant concrete of buildings.

Just return to your apartment and lock the door, she thought. Forcing her legs to move a little faster, the cheesh sound of her jeans rubbing together, the pat of her bare feet on the concrete. She heard a pop behind her and looked over her shoulder to see a brawly Neostarlite man, his body bright blue, a black circle around his chest, though his third eye remained invisible in the distance between the souls. A soul of Allah and a soul on the brink of a great darkness. A soul too soon escaping into the night sky. His naked body illuminated by the hovering street lights. One soul lusting after another.

She turned immediately and began hurrying down the street. Cheesh Chseesh Cheesh pat pat pat. Behind her she heard the pomp pomp pomp of the large man's feet springing off the asphalt behind her. pomp ротр ротротротротротротротр.

She lunged into her apartment and slammed the door shut, fiddling hastily at the lock as the pompompomp smashed into the door, throwing her backward as he stumbled into her living room. She scrambled forward and his hand clasped her shoulder, pulling her body downward with the fabric. He was too drunk, staggering back and forth.

"Wanna sshheee a night-tuh with a real man?" He stuttered in slurred Neo, the wobbling bulk blocking the front door. 
She tried to scream "help" but only a gargle of syllables splattered into the air. The man chuckled, his eyes nearly close, his point of balance dancing across the floor, his shoulders moving this and that way attempting to locate a steady position. She wrangled free of his tired grasp, scurrying to the basement stairs, once again attempting to slam the door in the man's face as he pushed his body on the wood until she stumbled back and he collapsed, face first, pushing her down a few steps as he rolled, and twisted to the body of the concrete slide, ротрротрротротр ротр ротр ротр ....ротр.....poтр....poтp.

And that was it. Twenty minutes of fear. Twenty seconds of accident. Death's eternal grasp on the Neostarlite.

They wrapped the body in an antique rug as the dawn broke. They just needed to leave the morgue before the 9am call for aid, the time for aid-workers to report to their posts in public hospitals, schools, and institutes. Only a few Natives were up before then, preparing for their daily labor jobs, or shuffling about to the market before the rich Neostarlite families they served awoke.

The morgue was positioned next to a Native graveyard. Jusanon dropped her at the gate and told her to be ready to go in twenty minutes. He could move the body to the pit himself. The graves were stacked on top of each other, staggering concrete columns, like small skyscrapers. An ode to old bones. Her grandmother's tomb stood so high she could barely see the engraving. She sat at the base of the stack, near the grave marker of a Mr. David Miller, a missionary killed 
hundreds of years before. Maybe that's what Asiya could be, a missionary, spreading the word of Allah to a new planet, helping to keep religion alive. But she thought of her DEP visa, a voluntary prison until Jusanon could prove her innocent. Can a Native ever be innocent? No praying in front of the parents, no fasting, no discussions. Just enlightenment in the purest atheistic form.

What had her grandmother always told her? Asiya, she had said, your name. Do you know why your mother called you Asiya? Asiya was the wife of Pharaoh. Egyptian, just like us. Despite Pharaoh's polytheistic empire, Asiya brought Moses into their home and worshipped Allah secretly. Just like we do. We wanted to remember that story, so your mother gave you your name.

And now, when faced with a dilemma, between her faith and her life, she fled. She fled to a planet with no afterlife, no soul, unlike Earth. The only Earth. The one which Allah sent Mohammad, the one that had survived for thousands of years. For what? For life. For Jusanon? He had done her so many favors so far, maybe he could do just one more.

She said goodbye to her grandmother. "Forgive me," she added.

At 9am the aid workers posted themselves at their designated stations, all of them hung over. All of them recounting the events from the night before. All of them proud of the enlightenment work they had been doing for the last hundred years to make Old Earth more civilized, more like New Earth.

But then at exactly 9:30 am, they all simultaneously received a message in their direct calling beams. A message that shook them with fear. 
Native, Asiya Khalil, aged 26, owner of "The Pyramid," arrested by Old Cairo police for the murder of Rajanon XR4, an aid worker living in Cairo. The body was found at the Old Cairo State morgue. After searching her home, they found a library of alternative histories and religious texts and items. Police recovered clear evidence of plots against the New Earth government, plots to perpetuate violence against the people, and plots to destroy rationality. She will be held in the Old Cairo Penitentiary until her trial set for the year 1155 . Please be alert of all Natives and report any suspicious or religious activities to the Department of Neostarlite Security immediately.

And then, at exactly 9:39 am, they all simultaneously received a message from their direct calling beams. A breaking story from New New York.

The Unadulterated Confession of Asiya Khalil Reported by Jusanon Y2P

My name is Asiya Khalil. I am a religious zealot. I am not an extremist because I want to kill. I do not want to kill anyone. I rather die than kill a being, human or Neostarlite. I am not an extremist because I want to destroy the Neostarlite government. My religion has little to do with politics, except for that a major aspect of my identity is banned. I am not an extremist because I want to bring the world to violence. I do not. I want to bring the world to peace. For those who practice rationality, I do not despise you. For those who practice Islam, I commend you. For any that commit violence in the name of Allah, I pity you for your lack of understanding. I am not an extremist because of my faith.

I am an extremist because you have labeled me an extremist. You have labeled my Christian friends extremists. My Jewish friends 
extremists. My Hindu friends extremists. My friends from faiths I do not know extremists. So we practice underground. For those who want to know what an average religious zealot looks like, here I am:

I am 26 years old. I own a restaurant. I am fluent in Neo. I wanted to obtain an MBA on New Earth. I really wanted to have a job in antiquities in the museum in New New York but I know the futility in that dream. I have no surviving family. Those before me were also Muslim. We never plotted to kill anyone. Only to read our Qurans. Pray. Fast. Spread kindness. Spread peace. This is what religious extremism looks like today. The most rebellious act I have committed is fasting annually. Of celebrating holidays. Of reading a very old book.

Last night a man followed me home from my restaurant. I do not know what he wanted or why he followed me. All I know was he became violent. Yes, a man dedicated to atheism and rationality became violent; a Muslim only wanted peace. As I fled he slid down my stairs and died. I feel terrible for this accident and am willing to accept my punishment.

I am taking my punishment not because I owe something to the Neostarlites, but because I owe something to the Natives. To the Native who believe but are afraid, I am with you. To the Natives who are afraid to open your Quran (or Bible, or Torah, or whichever way you choose to believe), I am with you. To the few believers willing to celebrate Eid, I congratulate you. To the Natives on New Earth who see religion locked up in museums, here it is free. Here we still exist. You are not alone. Do not forget your faith. Do not let the Neostarlite's take your identity. We are apart of something greater. Find your own enlightenment.

Signed,

A religious zealot. 


\section{Searching for Azrail Nick "Nasr" Pierce}

Author Bio: Nicholas Nasr Pierce converted to Islam in 2008. He is a third year law student at Loyola University, and an itinerant writer of prose living in Uptown, New Orleans. He has published numerous nonfiction pieces for The Daily Reveille, Morocco Tomorrow, the Huffington Post, and others. In 2014 he received an Associated Press Award for a column on the Boston Marathon Bombing. His first short story, The Silent Man, was published by Akashic Books in 2015. Originally from Baton Rouge, Nick holds a Bachelors in History from Louisiana State University.

Hani liked sitting in the sunroom. The great arched windows spilled light in broad pools across the floor. Hani would lay in them, and take warm afternoon naps like he had seen the kitten, Mishee, do. Today, though, Hani sat on the big rug near the door and played with his dollmen. They were made of smooth lacquered wood, and you could even bend their arms and legs and twist their heads around. Hani liked to stick small bits of cloth onto their featureless faces and pretend they had beards and turbans like Baba and his friends wore.

The Mufti didn't like that Hani dressed his doll-men up like real people, but Baba told the Mufti that Hani could do whatever Hani wanted with his doll-men.

Hani liked the Mufti too, even though he could be mean sometimes. The Mufti had a great big beard, but his eyes always sparkled when he told his stories or talked about Allah. Hani hoped Baba hadn't scared the Mufti, but he was glad his doll-men got to keep their turbans. 
Hani had not been in the sunroom since the day Azrail had taken Baba away from him. He had been napping with Mishee under the window when Omar, Baba's favorite runner, came to fetch him. Omar had carried him into the bed chamber where Baba had been staying for almost a week. Baba had looked tired the last time Hani had seen him, but that day--the last day--Baba didn't even seem able to stay awake.

That's what happens when Azrail comes, you go to sleep for a long time. Omar had told him that afterward, as he cradled a weeping Hani against his chest.

Omar had said it was an angel that took your soul to sleep; and that angel's name was Azrail. The Mufti had said that no one knew the angel's name. The Mufti said this was a weak narration, not true religion--but Hani didn't know what else to call him. Omar said that if you were good, Azrail would pour your soul from your body as gently as water from a pitcher--but if you were wicked, Azrail would rip your essence straight from your throat. The wicked, Omar said, always fought Azrail. They clawed to stay in their bodies.

They ran from judgment, while the righteous slept peacefully.

Hani liked Mishee and the Mufti, but he liked Omar the best of all. He was Baba's oldest friend, Omar had known Hani's Baba since before he was Hani's age. Hani liked Omar because he always smelled of musk and cigarettes, and he always made Baba feel better. Omar told stories too-spacer stories--funny stories and dirty stories, and stories the Mufti wouldn't have liked. But Baba let him listen anyway.

That day, two weeks ago now, Omar had carried Hani into Baba's room. 
It was so cold and dark and different. The servants had drawn thick curtains across the windows. Better to save Baba's eyes from the light than to cause him any more pain, the Mufti had whispered. Hani didn't know why Baba would not rise, why he did not walk to Hani and crouch down to shake his hand. Whenever Hani had not seen Baba for a while, Baba would greet him this way--a twinkle just beneath his hard, flintcolored, eyes.

"The test of the man is in his hand," Baba would say, cupping Hani's little paw in his own rough fist. But this day, Baba did not so much as move beneath the thick comforter. The Mufti called it poison--secreted into Baba's food or drink. Hani did not understand that part, either.

Omar had gently lowered Hani into Baba's bed, and Hani had curled up next to his father. He didn't want Baba to sleep, he didn't want Azrail to come, he wanted Baba to stay awake.

Hani was so scared then. Baba scared other men. Hani had once overheard Omar saying that, too. Some people loved his father, others respected him, but everyone feared him. That's what Omar had said. Not Hani though. Baba always smiled for Hani and held him against his chest, solid as an oak tree and as warm as Mishee's naps. Sometimes, Baba would pick him up and swing him around and they would laugh together. Then Baba would put him down, dizzy and shaking, and his father would mutter something about Hani--and how he reminded him of his late lady wife. That day, though, Baba was different. Cold, and still, and white like the linen sheets.

This was not the Baba Hani remembered.

Hani remembered Baba the way he had looked on Parade Day, when the big capital ships of the home fleet would fly low through orbit above the 
citadel and his father would sit upon the great chair overlooking the millions of people crowded down below. Hani would sit next to him, sometimes, and sometimes the Mufti too.

If Latif was home, he might sit on the chair instead of Baba, but Hani had only ever seen that happen once.

That was before the Frog Men started their war, before Baba got sick, and before General Ismail ran away. Hani wasn't supposed to know about General Ismail, but he had overheard the kitchen men talking about it over their boiling pots. Even young Hani could hear the worry in their short, sharp, whispers.

That had been two days after Baba had gone, but before they told Hani the angel had come for his brother, too. That day it was the Mufti that came, not Omar, and the servants had stripped little Hani and bathed him in a tub of rosewater and lilac.

Hani could hear the washer women talk softly as they pulled the knots from his hair.

The Frog Men had caught his brother, Latif, as he lead the fleet from their defeat at New Jaffa. He fought valiantly, the washer women said, and it looked as though he could have turned the tide and won the battle. But the great ships he commanded, though strong and fast, were no stronger or faster than the Frog Men's fleet.

Later, Hani had hidden behind a column in the courtyard and heard the janissaries say that General Ismail had no love for Latif or Hani's Baba-and that's why General Ismail ordered the fleet to retreat when big brother Latif had ordered them to charge. 
Their faces seemed grim in the guttering torchlight, and Hani had been scared then too.

Hani did not remember his brother much, but he loved him nonetheless. Latif was always running from one distant star to some other far flung planet. But when he came, as rare as that was, he would muss up Hani's hair, smile, and surprise him with a gift.

Once it had been a dancing camel, hewn from pine grown on Syracuse. Another time it was a music box crafted by the tinkerers on Little Punjab. The last time he came, the gift was a stack of books as thick as Hani's head, brought as a present from the scholars at the Imperial Madrassa on New Baghdad.

Hani didn't like that one too much, but it had made the Mufti grin.

“The people's business never sleeps, little brother--you will know soon enough." Latif would say with a tired smile when Hani begged him to stay.

But he always threw his cloak over his shoulder, and flew away again.

The fleet got confused, the soldiers had whispered in the dark, but they chose Ismail and life over Latif and death, and that is why Azrail took his brother--out alone in the darkness of space.

Hani hoped the angel poured gently.

That day, the day of the lilac bath, the Mufti had dressed him in a fine emerald tunic and tied a tight golden turban around his head. The Mufti lead him through the citadel and to the lavender divan Baba would recline on when he listened to the common people come with their complaints. 
Every step he drew closer to the big pillow on the floor flowers drifted down like snowflakes. Hani glanced up, scared to take his eyes from the Mufti, to see girls no older than him running with baskets of white rose petals along the balconies above.

When he got to the pillow the Mufti turned him around, and strapped the Sword of Osman--Baba's sword, and Baba's Baba's sword--to his waist. The blade was longer than Hani was tall, and Hani was scared the weight of it would pull his pants down. The Mufti raised his hands and recited Surah Al-Fatiha, the first chapter of the Qur'an.

Hani loved to hear the Mufti recite, but that day he found little comfort in it. When the Mufti was done the crowd, pressed together along the walls of the court, grew still.

"Hani ibn Jaffar ibn Ahmed ibn Mustafa ibn Osman, now called AbdulMajid VI, has been girded with the sword of Osman!" The Mufti cried, his voice cracking ever so slightly.

"Long live Emir-al-Mumineen. Allah preserve his dominion, his line, and bless his wives and children. Ameen." The crowd replied.

Emir-al-Mumineen? Hani had thought, tears gathering at the corners of his eyes. Baba was Emir-al-Mumineen, Baba was the Defender of the Faithful. How can I be the defender of the faithful, when Baba is?

Hani began to cry. He missed his Baba so much, and his brother Latif even though he never saw him, and Hani missed his mother too, even though they had never met.

Hani was anxious to see Omar again, too. The old runner had been absent since that first day, the day Azrail came for Baba. Hani hoped Azrail had left Omar alone, wherever he was. 
Baba had always said everyone wanted the Sword of Osman, even though they didn't know what it truly meant to hold it. Hani thought if he were to meet Azrail he might trade him the sword for his Baba back. That thought made him sob, and a low sigh swept through the crowd as Hani's tears rolled down his face and pooled on the satin pillow.

The Mufti knelt next to him, eyes soft and broken.

"Come little one, let's get you upstairs." The Mufti whispered in his ear, and Hani thought he could see tears on the Mufti's own cheeks too.

They had left him alone after that, locked up in his room with no one but Mishee to keep him company. They would bring food and water, and sometimes the Mufti would sit with him for a moment or two, never speaking, eyes ringed with worry.

This morning had been different. The janissaries had brought him to the sunroom, and stood outside arguing in low tones. That is why Hani had picked up his doll-men, and scooted close to the door. He wanted to hear what the soldiers were saying. But when they had seen him inch closer, they had slammed the door shut. Hani couldn't make out what they were arguing about through the thick mahogany, no matter how hard he pressed his ear to the door.

Near midday, Hani looked to the windows. Any moment, the minarets throughout the city would begin the call to prayer. A lifetime in the citadel had made the muezzin's song a daily part of Hani's life, and he had started taking comfort in it's somber peaks and valleys.

Instead of the adhan, though, a terrible siren rattled the glass panes.

Awwwwwoooooooo00000 
Hani could hear the soldiers now, their muffled voices shouting above the alarm.

Then, the door thundered open and a janissary in his bone-white helmet stretched out an arm, "Come to me child! Quickly!" The soldier commanded, his blue eyes wet and unfamiliar.

Hani stood to obey but a deafening explosion punched the janissary in the back. The soldier's chest exploded, the force of the blow tearing through his armor and sending a stream of red sludge and bits of bone washing across the floor.

“Hani! To me boy!”

Omar stood in the doorway--an ugly pistol still smoking in his hand.

"Amu Omar!" Hani screamed and jumped over the leaking janissary slumped on the rug. He ran to Omar and latched himself around the old pilot's leg, too scared to cry.

"Come on son, we have to move." Omar said, scooping Hani up and slinging him over his shoulder. Hani could see Omar wasn't alone now, there were several janissaries with him too. They were identical to the one Omar had just introduced to Azrail, but Hani recognized these.

Bassam, with his green eyes and red hair, Lutfi, the man that stood behind the purple pillow and always slipped him treats, and Akram and Sayyed, the men who guarded Baba's door at night. They were members of Baba's personal guard, all of them--and sworn upon the Holy Qur'an to protect him--and Hani--with their lives.

Where were they when Azrail came for Baba? That thought made Hani angry. He could see past their stony faces now, down to the open-air courtyard just below. 
The janissaries...are shooting.

Hani could see them cowering behind columns and marble verandas, their laser rifles spitting bright red beams of death across the yard. The lasers arced wide and long and seemed to be jumping across the court at random. It was chaos.

Omar started running, and the guards kept pace with their own rifles held at the ready.

Just as Omar rounded a corner, Hani watched a sharp red beam find its mark. The janissary was running between columns when an electric bolt caught him in the gut and sliced him near in half. The soldier tumbled and slid, leaving a slick trail of blood on the smooth marble floor beneath him.

They're shooting each other.

Omar kicked a door open, and suddenly they were outside--running across the sandstone causeway from the citadel's royal chambers towards the starship hangar. Hani could see now from his perch atop Omar's shoulder the beautiful cherry-red skyline of the castle and its surrounding metropolis. From the causeway, Hani could see flashes of red in citadel windows. He could see smoke rising from the janissary barracks. And he could still hear that awful siren.

"Subhanallah..." One of the men groaned, stopping to stare straight overhead.

Above them, the bright silhouettes of warships exploded in high orbit. Hani could make them out against the darkening sky. He could see them flash and charge, firing massive red lances of light at one another. Through one another. 
Azrail is busy, Hani thought from a thousand miles away.

The bad janissaries were on them then, chasing them, pouring through the door Omar had kicked open.

"Into the hangar!" Omar screamed, and the men followed.

The hangar was empty save for a single sloop, a royal courier's ship not much larger than an old fashioned ground bus, and kind of shaped like one too.

The hatch slid open, and a ramp descended to the steel-mesh floor. The Mufti slid down the ramp, his black leather socks gliding down the polished steel. Omar slung Hani roughly into the Mufti's arms. Hani could see the door to the hangar now, and the good janissaries had formed up in two solid rows, the front row kneeling, the back row standing--their laser rifles leveled at the door.

“Omar, quickly, aboard the ship!" The Mufti yelled as he pulled Hani up the ramp.

The Mufti shoved him into a seat, buckling him in and turning back to the hatchway.

“Omar, come now!"

"Save the boy!" Omar screamed and slammed a fist against the external latch. The hatch door started to slide closed, and Hani could see the Mufti struggling to stop it.

"Sheikh," Omar said softly through the glass porthole, "there can be no sultanate without a sultan. Save the boy," he repeated. Hani could hear them firing now, he could just barely see them charging through the 
door, the janissaries on top of one another, some firing, some stabbing with their wicked sabers.

The ship, apparently on autopilot, lit it's engine and began to hover. Hani twisted in his seat and looked through the window behind him just as the sloop began to turn and move towards the exit. Omar, ugly pistol in hand, was shouting commands and pulling the trigger over and over again. Hani watched the first red beam cut through his chest, then another through his stomach, a third through his leg and finally a fourth straight through the eye. Omar collapsed as the little ship lurched from the hangar.

The Mufti fiddled anxiously with a dial on the armrest of his chair, tuning into and catching bits of chatter across the comms, "la illaha il Allah..la illaha il Allah..." and "..ong live the Sulta-" were all Hani could decipher.

As the tiny ship rocketed towards the black of space just beyond the horizon, Hani could see a massive dreadnought break the atmosphere and spiral down towards the city, bleeding air and fire as she went. This ship dwarfed their own, and Hani could just barely make out the warship's name painted in sharp Arabic calligraphy down the hull. Hani's Gift...that's my name, Hani thought.

Hani watched as the warship collapsed on the domes and spires of his home. Even up here, miles away and moving fast, their own little boat shook violently against the blast. Hani watched the explosion as it bathed the citadel in dull, blue, nuclear fire. Hani pressed his face hard against the window.

"What are you doing, child?" The Mufti asked quietly, voice drained of all emotion. 
"Searching." Hani said.

"For who, youngling?" The Mufti asked, as he pressed his own face against the window.

"Azrail." Hani whispered. 


\section{Watching the Heavens Peter Henderson}

Author Bio: Peter Henderson is a freelance writer based in London. He has previously lived in Syria and Iraq, as well as in China and several European countries. He is interested in how societies fit together.

I followed Jan as he ran through the narrow, dimly lit corridor, both of us stooped low. I was out of breath before he stopped, opened a side door and pulled himself through it. I saw a small room, bright in comparison with the corridor, with benches along one wall and lockers along the other. The benches stood about a foot off the ground, so when we sat down our knees were nearly level with our chins. Neither of us spoke for some time, both of us catching our breath.

'What on earth was that?' I finally asked. 'And why did we have to run?'

'That was one of our employers' business partners, you could say.'

'You don't mean...' I had to let my thoughts catch up. 'That thing, that was an alien?'

\section{*}

The dawn azan from a thousand minarets was sweeping in from the east like a sunrise as I left the hostel, overtaking me as I walked down the coast road and rushing westwards with the spreading sunlight which struck the domes and spires crowding along the shore before me. A blue eyed man, gaunt and with his blond head uncovered, waited for alms under the eaves of a mosque. His eyes were sunken and faded. I turned away and hurried on towards the job market, afraid of the coming heat. A service ship hummed overhead; a police van glided past silently. 
The open square was busy but not crowded, a thousand long-shadowed men like me trying to catch the phone numbers as they flickered past on the digital display. I saw a few men shoving at their friends to hurry them; some more generous workers would lend their phones to people without them once they'd found work for the day. The jobs carried on ticking by: electronic cable layer, 10 dinars a day; solar panel cleaner,12 dinars; cargo loader, 8 dinars. I entered a number at random. Immediately a man answered.

'How old are you?'

'23.'

'Are you fit? Not injured?'

'I'm fit.'

'Come to the entrance of port 7. Quickly.' He hung up. Port 7 was back along the coast to the east. On a side of the square a line was growing by the bus stand. The line was quiet, gently pushing to and fro and the smell of sweat hanging heavy, but moving steadily forward as shuttles arrived and departed. On the bus the camera lights blinked. No one spoke.

After twenty minutes we got to port 7 and I got out of the bus and joined another line at the gate. After I'd passed the metal detectors I entered a low building with cubicles along one side. When a cubicle became free I walked up to it. A man sat at a desk with a computer, the screen recessed so I couldn't see it. 'Identification,' he said. I handed the card I'd bought with the money I'd had left after getting the phone. 'New arrival?' the man asked. I nodded. 'How did you arrive?'

'I came to the main passenger port,' I said.

He exhaled sharply and looked at me. 'You came on one of the seaships. Still, you're lucky, we need men today. I'll put you down as a previous 
worker. A bit of advice though - get a new ID. That one won't get you past anyone but the more stupid security guards. After the explosion last week they're not taking chances.' He looked suddenly uneasy, as if my face had shown too much interest. 'You hadn't heard about that? No reason for you to know, I suppose. Listen to me: don't go talking about it. Alright? You'll just make your life difficult.' I nodded. 'So, 8 dinars for the day; you get a meal at noon. Ten hour shift. We'll take off half a dinar for your jizya payment, and you'll get a slip to prove it at the end of the day. It's easier than expecting you people to self-report what you earn. Alright?' I nodded again. 'Good. Hand here.' I put my hand in a device and felt hot ink sprayed onto my skin. The barcode was dry as soon as I pulled back my hand. 'It'll last for the day. Now, down to the end of the room, turn right out of the door, go to bay 4 , and you'll find your team leader. Go in peace.'

I left the building and saw bay 4 and joined the men milling there. Most were light skinned like me. Some were speaking in Italian, a language I recognised having heard it on my way from home. I saw a group I guessed were Germans, and others who could have been from further north, Scandinavians or Baltics. All of us together, scrabbling for 8 dinars minus jizya. The foreman arrived, shouting, and got up on a podium.

'Right! Groups of six! Get on with it!' We divided like clams in a wave. 'Remember each other, I don't want to have to reorganise you. We're loading cargo onto the ship in berth qaaf today, the offloaders are finishing now. Any rookies?' A couple of us raised our hands. 'For those of you who haven't done this before: attach the cable hooks to the containers, get out of the way when the crane is moving them, help the crane operator get them in the right position without any wasted space 
on the deck, detach the cable hooks. Don't get your hands stuck or you might lose them and then you won't get paid because you can't show your barcode when you clock off.'

We were marched up the ramp and into the ship's loading bay. It was almost unimaginably big, the walls and ceiling disappearing into blackness. Columns of containers a hundred metres high took up half the floor space, and trucks and loaders were moving slowly, getting ready to fill the rest. The floor was marked with thick green lines showing where the containers should sit, with grab claws recessed in the floor beside them. One of the workers slapped me on the back.

'So, I'll partner you today. I'm Jan, I've been working here for a few months now, and I think today is your first day, yes?' He spoke loudly as we jogged across the floor of the cargo hold.

'That's right,' I said.

'Well, that's fine. I'll let you know when you're doing something wrong and really, what the foreman said about getting your hands out of the way quickly? That was true. I've seen men lose their hands. Don't think it's a clean cut either - the wrist gets smashed. One man I saw had the bones ripped out from his lower arm, and he was just left with bloody, hanging flesh. And then, really you're finished. You can try to go to the mosques for help but they won't support you for very long. The last time I saw that man, he said he was going home. I heard he set out from the beach in the night like he was going to swim back to Europe. That was that of course.' He shook his head. 'Anyway, like I say, be careful.'

'Thanks. I'll follow your lead. Where are you from?'

'From Poland. I think you are German?'

'No, I'm English.' 
'Ah, the English. I always imagined this was harder for you than for us. A longer fall, if you know what I mean.'

I said, 'It's all the same now, isn't it.'

'Yeah. Yeah, it is. Just because of these deserts.' He sighed. 'Ok, here it comes. Just watch me for now.'

A giant forklift approached silently apart from a gentle beeping, flashing lights matching the rhythm of the beeps. The container came forward to us and stopped just above the line of the floor, then descended. Jan jerked forward, quickly unclipping a metal hook from the bottom of the metal box and pulling away as it disengaged and disappeared like a snake. Then he bent down to the floor and lifted part of the recessed metal, before springing back as another hook rose and connected to the box. Ten metres to our left another team did the same and the end of the container, and ten metres to our right it was again repeated.

'That's it?' I asked. Jan laughed.

'Say that in twelve hours' time. And for another thing, sometimes the placing isn't straight and you have to signal the driver the get it right, and then there's the times the hooks don't work properly and you have to engage them manually. Once we've done this level and we're working higher up there's the risk of falling as well. And don't talk about it like that, you'll tempt fate.' I nodded.

For about two hours we worked, although Jan really did everything and I just watched him. He had me detach the hooks a few time, holding onto my belt as I did it and pulling me back immediately, just to make sure I got the message. The work was unrelenting and monotonous. My back began to ache from bending. I stood up and stretched, and stepped back. Behind us there was a narrow corridor formed by two container columns, not much more than a foot wide, but rising far above us. A 
light breeze came from it, from the air being pressed between the columns. A strange smell, like warm, wet moss, was in the air. I stepped into it, into the cool darkness and the breeze.

'Hey, don't go down there! We have the next container to do...' called Jan - but it was too late. I felt a sticky liquid under my shoes. It bubbled as it came into contact with them, and I felt the steam rising. My eyes began to get used to the light and I began to make out a loose shape on the ground. Jan was behind me.

'Oh, no. No! This is bad. We have to go. Now! He pulled me back into the light and marched me hurriedly past the container we'd just laid and down another narrow corridor, ignoring the shouted questions from the other workers. As the thick darkness again surrounded us, the shouting intensified, and Jan pushed me into a run. He made a sharp turn left, then right, then right again, pulling me by the sleeve. A recess behind one of the containers, lit up by small diodes, had a service hatch which he pulled open, pushed me into, and the clambered in. I began to feel my shoes dissolving.

\section{$*$}

'You're bitter,' said the policeman.

'Of course,' I said.

'Such is history. It is the will of God.'

'The will of God? You know I don't believe that. It was blind luck that you didn't deserve. What happened? The world was spinning normally a couple of hundred years ago and then the aliens arrive. They come down to the deserts and they said, you're on our trade route now that the stars have moved or whatever it was, and they set the designs for their ports - your ports, however you want to think of them - next to the sea, all along the southern Mediterranean and around Arabia, so 
they could use the water as a coolant and then they delivered the solar panels, so many that the whole desert's been covered by them. And then the world economy collapsed once the only way to make real money was to be running the ports and getting a cut of the interstellar trade. To say nothing of the Mediterranean which is wrecked from having hot waste water pumped into it all the time. And now there's no money and no jobs in Europe. A thousand years of Western civilisation finished because some aliens drop out of the sky.'

'The will of God. What else can you say? How can you explain these things? The deserts have bloomed!'

I followed Jan as he ran through the narrow, dimly lit corridor, both of us stooped low. I was out of breath before he stopped, opened a side door and pulled himself through it. I saw a small room, bright in comparison with the corridor, with benches along one wall and lockers along the other. The benches stood about a foot off the ground, so when we sat down our knees were nearly level with our chins. Neither of us spoke for some time, both of us catching our breath.

'What on earth was that?' I finally asked. 'And why did we have to run?'

'That was one of our employers' business partners, you could say.'

'You don't mean...' I had to let my thoughts catch up. 'That thing, that was an alien?'

'Mmm. Yes, that was not human. You haven't noticed the colour of the blood yet. Or what it's done to your shoes.' They were stained blue, and the rubber on the undersides had softened and was starting for melt. I prodded at the sole with my finger. It was soft. I sniffed my finger. It smelt faintly of raspberries. 'You're surprised because you thought they never came out of the ships' control sections, yes? Well, sometimes they 
do, mostly, from what I've heard, for one of two reasons. For one, sometimes they need to arrange a matter with the port management. Most of the time that's done over the communications systems, but sometimes there's a captain who wants to be a little bit more personal. The other reason - well, they're intelligent beings, aren't they? And intelligence and curiosity are kind of the same thing. So, sometimes one or two of them will sneak out, have a look around, and try not to be noticed when they go back to their quarters. It's discouraged apparently - they think we might have diseases. And there's the risk that one of them might try to have its way with us...'

I interrupted, 'So you've seen them before?'

'No, I haven't. I've spoken with a couple of people who said they had, though. Only quick glimpses, before they ducked out of sight.'

'But you're still sure that was one of them?'

'I'm sure. I mean, what else could it have been? The size fits at least.'

'Fine, ok. So that was an alien. A dead alien. You didn't kill it, did you?'

'No,' said Jan, 'no I didn't. I've no idea who did either, but you have to agree it's convenient.'

'It's convenient? My shoes are ruined, and we've run away from everyone and we're hiding... This is not going to look good!'

'Ah, yes, we're hiding. Sorry, I'm still thinking about what it would be like to have one of them jump on you...'

'Why did we run? Won't that look bad? Won't it make people think we did it? I have to walk out of here! It's not just us!'

'I mean, we don't even know how they work like that. Are they males on the ships, or females... do they even have male and female? If a female jumped you, would it be like with a woman? Would it be better maybe...' 
'Why did we run!?'

'Oh, running. Well, it's quite convenient.'

'I get that. How do we explain it though? I mean, what are the chances of the police believing that we didn't kill it?'

I looked at the floor for a couple of minutes. This was not a situation I wanted to be in. It didn't fit. I hadn't come risk my life trying to convince the police I was innocent of something I hadn't done. I was trying to shape what had happened into a story that made sense. From the way he kept twisting and contorting himself, Jan was trying to understand the alien's physiology. He suddenly stopped, completely motionless, and said, 'It doesn't have to be both of us. I just need enough time here.'

'Here? This is the place?'

Jan smiled broadly. He teeth reflected the green light of the cabin. 'Here. Go on, leave me to it. You can think of a story.'

'Yes.' I got up and opened the door. Jan called me back.

'Wait - what size are your shoes?'

I told him and he grinned. 'Mine too. Very lucky. So we switch.' We swapped shoes. His stank. 'Go now. Say what you like and I'll play it up.' 'Alright. Jan, the alien thing - I mean, you were talking about having sex with them...'

'Yes?'

'Are you serious? Like, really, genuinely serious?'

'Why not?'

'Because they're aliens?'

'When do you think was the last time I had a woman? The mind wanders.'

'I don't think it wanders there for most people. Um, do you mind if I use that? For the police?' 
'Why not? If it's useful, go ahead. Now go, I need time.' As I left him in the cabin he resumed his jerky movements with his imaginary alien, his tongue sticking out of the corner of his mouth with the concentration of it, and the door slid shut behind me. I was cold again for the first time since on the open boat on the sea crossing. The corridor was quiet, without even an electronic humming. I followed it away from where we'd come from, trying not to make a noise. As soon as I found another corridor I turned down it. A small door marked by sharp blue lines, that I was able to open manually, opened onto a dim cargo area; there was no way to know if it was the same one we'd left.

I rubbed at the barcode still on my arm but the ink stayed firm as my skin went red and burned. I thought about the story I'd tell. If they believed me, I'd still have to worry about my false papers. Maybe that wouldn't be such a big deal if they believed me; lots of workers must have used false papers. I would have to play up Jan's weirdness. Besides, if the dead alien was any kind of female he'd virtually incriminate himself. That was it, then. Good luck to me.

I broke into a run, adrenaline lifting my spirits with the strength of a decision made. I ran towards the light shouting, 'Help! Help!'

The policeman stroked his luxuriant moustache. A glass of tea steamed before him. 'So, John Valette. I am to trust everything you say. You are an ignorant illegal worker just off the boat. You were an agricultural labourer in Europe, despite your hands which I note are softer than mine. You have only a basic education, yet your Arabic is good enough that you could understand that of ...' he looked at his notes '... Jan Sobeiski, which I can tell you is no easy thing, and he does not speak English and you have given no indication of speaking Polish. You 
stumble on a dead alien and Jan with it, and then you follow him in what you describe as a fit of panic. You then decide that Jan is not someone you wish to associate with and that his, we could call, predilections, suggest that he is in fact responsible for that alien's death. You are able to escape him and make you way to a group of workers to call for help. Am I fairly summarising?' He looked somehow eager to please me.

'Yes, sir.' I spoke timidly. The office was cool from the air conditioning. I could feel my skin erupting in goose bumps. The hairs on my legs stood up against the cold, my bare feet clammy on the floor. Metal cuffs held my wrists to the chair's arms.

'Hmm. Well, if you want to tell it like that. I don't mind, and I am being honest about that.' He punctuated his speech with friendly nods. 'Let me tell you one thing. I don't believe you.'

I struggled to keep my breathing regular. I needed desperately to swallow. The policeman said, 'There is more about you than you are claiming. And these are, can I call them, difficult times, perhaps. Some people are not as happy as they could be. Unhappiness can make us do foolish things - and yet it is so easy to be happy. When I look into your eyes I don't see a happy person. I look into people's eyes, Valette. I am good at looking deep into people's eyes and knowing what they are feeling.' He tapped his pencil on the top of his desk. 'When the port officer mentioned the explosion to you this morning, you tried not to react. Like you're doing now. I've watched the tape very carefully, Valette. When he told you about the explosion, you were surprised, yes, but something else that you hid quite well. You were happy.'

'I...' He cut me off.

'No, please don't say anything. Now, for now, it's convenient for me to believe you. Dead aliens are bad for business and the port authority is 
very unhappy. I'll solve the murder, if that's what we should call it, and we can draw a line under it. Killing an alien is an automatic death sentence - not legally, I mean, but practically, it's an agreement we've come to with our business partners the aliens. You aren't passed in front of a Christian court to confirm the sentence like for other crimes. We've tried to make sure everyone working in the docks knows.' He shrugged. "The port is money. Once we realised that some of the aliens were creeping around on their time off, we saw the obvious risks. So if you're happy for...' he looked again at his notes '... Jan Sobeiski to die for something I am sure you know he didn't do, that's fine with me. Except, it does make me so very interested in you.'

'I'm sure he killed it! I mean, I didn't see him do it, but he was standing over the body, and what he was talking about...'

'They have exoskeletons, Valette. If you want to kill one you need a gun, or a sledgehammer and a very obliging alien that doesn't move while you smash it in.' He smiled indulgently. 'Too bad the light was so dim. Ah well. So, I am going to accept you story as far as the paperwork is concerned and we'll send it up to the qadi, and then I'm going to let you go and have you followed, and sooner or later you will reveal what you're really here for, because, Valette, I am sure it is not just to work at the docks.' He beamed wide and my neck crawled.

The policeman had me testify at the trial. Jan sat in a wooden chair away in the centre of the wide courtroom. The qadi kept things brisk; a Catholic priest sat beside him - since the victim wasn't Christian they hadn't given Jan the option of a Christian trial, but the priest seemed to be there to show willing. There were also a couple of lawyers taking notes; otherwise the court was empty apart from a small group of men 
in black robes and neat little black beards at the back of the room who whispered to each other from time to time. I assumed they were from the trade ministry or the port authority; one of them was holding up a camera and recording what happened. Jan seemed almost nonchalant he knew the outcome anyway - but he kept his eyes on me for as long as I was in the room. I stared at the floor. When the qadi prompted me, I recited my testimony almost from memory.

'I was working with Jan. I noticed he had gone and looked for him. I found him next to the body. There was a lot of blood so I knew it was dead. Jan had his hand inside his clothes. I was shocked and frightened. Some other workers were coming but then Jan pulled me into the service tunnels and I followed him because I didn't know what to do. $\mathrm{He}$ told me he'd blame me if we were caught. He made me stay with him in a side room until I was able to escape and get help.'

The qadi nodded. The priest sighed. Jan scratched himself. The qadi said, 'The defendant allowed you to escape?'

'He was not paying attention to me when I left. He was, er, thinking about the alien...'

'What do you mean?'

'He was thinking about whether it was male or a female. He was wondering what it would be like to...'

'Oh, good heavens!' the priest whispered in shock. The qadi gave him a severe glare and the priest exhaled and looked apologetic.

'You are saying he was distracted by imagining being in intercourse with the alien?'

'Yes. He was very interested in that subject.' Jan sniggered and I looked at my hands. 
'The defendant will be silent! Witness, that will be enough from you. Take him out.'

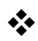

My fingers were shaking as I entered the code we'd agreed on. 1-5-7-1. Two wires stuck out from the metal back of the locker, one red and one blue, taped to opposite sides of the locker's walls, their copper tips exposed. Another explosion outside was close enough to rattle and shake though the ship's body. I heard distant shouting and screaming and the sound of huge hatches clamping shut and then a sudden weight pressing my feet into the floor - the feeling of the ship leaving the ground. I braced myself against the open locker and checked my watch. 13:59. I watched the second hand move around the face. Ten seconds, the slowly, so slowly, five, then two. Time for one deep breath.

The policemen came into my cell sometime later, holding a pot of tea and glasses which he set down and filled. I waited for him to gesture and then took one.

'You did well enough. Well, it didn't matter especially anyway. But I am very pleased with you. Yes?' He looked at me, almost imploringly. 'And I am going to reward you. No, take you time, don't drink too quickly. Yes, reward you.' He beamed at me again, then the smile dropped and leaned towards me, looking at me very intently. 'You will be good for me. You are my big chance. You will - arghh!' He pulled back his hand from the teapot. 'Damn thing, too hot.' He waved his fingered and then sucked at them. I finished my glass.

The policeman led me into a small courtyard. The qadi and the priest were there already, and the robed men too, each now holding a 
notebook and pencil apart from the one still holding the camera. After several minutes of standing awkwardly - I tried to avoid the priest's glaze - a pair of guards led out Jan and knelt him in the centre of the courtyard. I wished I wasn't there but Jan saw me as soon as he'd blinked away the sunlight. He winked at me, grinned, and then snarled at me. The qadi walked up to him and said, 'You have heard your sentence. Do you have anything further to say?'

'Not to you,' Jan growled and the qadi stepped back, the priest replacing him.

'My son, do you wish to confess? It will please the Lord that you return to him unburdened by $\sin . . . '$

'Not to you, either, you damned Italian fool.' I was sure one of the robed men stifled a smirk. 'Just stand in the corner and do your muttering.' The policeman leant towards him. He whispered something. 'So that's where it is?' Jan smiled. 'That's a nice thought to go out on.' His head spun off and landed a few feet away on the sand and blood sprayed up from his torso and it slumped. The executioner who'd stepped silently out of the doorway cleaned his sword with a rag.

The qadi stepped back so the blood wouldn't get on his shoes. 'I know you can't choose your congregants, father, and I'm sure we have odd types ourselves, but he really was very, very strange...' They filed out leaving the policemen and myself and the executioner putting away his sword and pulling out a body bag. The policeman smiled. 'Alright?' he said, and patted my shoulder, resting his hand there for a few seconds.

The day's heat had subsided on the street as I walked to the restaurant near the hostel. I ate a meat kebab and paid with a couple of coins. The black, unmarked police car was parked unobtrusively some way away, 
but close enough to make sure I knew it was there. I returned to the hostel and went to sleep.

In the morning I passed the old man outside the mosque again and went to the jobs market. I got a place in another of the ports. My new identity card seemed more effective than the old one, and none of the administrators asked me any questions. The work was cargo loading again. No one asked about Jan, either because they hadn't heard or because they weren't interested. I didn't try to talk to anyone either. In the evening I ate at the same restaurant and went back to the hostel. The black car was always in the background. After two weeks the car pulled alongside me and I was told to get in. We drove towards the city, the surroundings getting less industrial as we went, passing streets and houses and apartment blocks and a hundred mosques. We stopped at an unmarked house, lower than the buildings surrounding it. Uniformed men and ununiformed ones moved around inside. I was taken to an office and told to sit on a low sofa, and I was given water. The azan began. I was left alone and a deep and soft silence settled for some time before activity returned. The door opened and the policeman came in. He smiled.

'Do you have anything for me yet?'

'No.'

'Soon?'

I frowned. 'I'll try.'

'Perfect. Thank you.' He stood up and walked to the door. 'Don't hurry. Finish your water before you go. You didn't want tea, did you?'

I said, 'I'm fine.' He smiled and left 
A few days later I was ready. I stayed at the hostel instead of going to find work for the day. I found some scrap paper by going through the bins and a stubbed pencil. I looked at the paper for a long time before I wrote down two names that I remembered, names of people I'd never met. I hoped they would have had time to finish what they'd been supposed to do. They should have, anyway. I sat very still and felt the sun passing over the hostel and the pink-tinted sea and the coastline with its endless city stretching away along the coast all the way to the Pillars of Hercules and past them. I felt the shadows start to lengthen outside and heard the hovering sound of the azans coming from the east, marking time passing. The day waned and the city released itself as dusk fell and the heat dissipated. I heard the traffic increasing and the workers coming back to the hotel.

I got up and walked outside. The houses sat stolidly against the road, each with its metal-framed door, the windows few and high up. They sat oppressively, heavily, like the ships did in the ports. I'd heard they were different inside, all space and light and coolness. Well, they were not meant for me. Despite the streetlights, I could see a few stars: the great bear pointing to Polaris, Polaris pointing to the north. I kept walking until I came to a mosque with double minarets and a cable strung between them from which green lanterns swung. I paused outside for as long as I could without loitering. Inside I watched the men around me and took their cues, removing my shoes and mimicking the ritual washing they performed. They were workers with dusty overalls, taxi drivers and train conductors in sweat-stained uniforms. I knelt on the worn carpet at the back of the prayer hall for a while. I didn't try to copy their prayers. I got up to leave, and as I passed the alms box, dropped the paper inside. 
The next day the port was very quiet. No one spoke more than they had to. The authorities had put up posters beside the metal detectors so everyone would see them. Two severed heads lay on bloody sand. 'The crime of illegally disrupting commerce can carry the death penalty. Two criminals have been executed for attempting to interrupt the free flow of goods. Ministry of Justice.'

'Thank you,' the policeman said as I sat before him in his office.

I shook my head.

'Do you have anything more for me?'

'No.'

The policeman's brow fell. A disappointed child. 'Ah. We are hoping not to have to wait too long for more. We must keep showing results, you see. Well, tea.' He poured two glasses and gave me one. 'Tell me about your work at the docks.'

'There's nothing to tell. It's routine work. Just blending in, doing what I'm told to. Are you interested in it?'

'Why not?' The ingratiating smile again.

I shrugged. 'It's repetitive. We guide the containers into place and secure them, then do it again. I don't know how many in a day. Could be a hundred maybe. I don't count. We don't talk. Maybe Jan was an unusual like that. He talked a lot. Or maybe word's got round and everyone's scared. No one's mentioned him anyway.'

'He was a very unusual man.'

'Yes, very strange.'

'Do you feel bad about him?' 
'I don't think so. There's no reason to, really.'

'Really? You let us kill him knowing he was innocent. You used him to protect yourself.'

'Maybe he wouldn't have minded.'

'If he knew?'

'If he knew.'

'You think so? He didn't seem like someone who would care for causes and ideals.'

'You weren't paying attention then.'

The policeman's eyebrows rose. 'I try very hard to pay attention. Tell me what you mean.' Almost beseeching.

'His name. You don't think it was real do you?'

'We looked into it. It's the name he registered with when he arrived. There was nothing about who he was in Poland but that's normal. They're not keeping records there anymore, by the sounds of things.'

'Maybe not. But Jan Sobeiski was the king of Poland who led the relief of Vienna from the Ottomans. It was a great defeat that kept the Turks out of the heart of Europe.'

'Ah. Well, I admit that we've stopped paying attention to that part of our history. It seems not to matter so much anymore.'

'I can see that.'

'You're bitter,' said the policeman.

'Of course,' I said.

'Such is history. It is the will of God.'

'The will of God? You know I don't believe that. It was blind luck that you didn't deserve. What happened? The world was spinning normally a couple of hundred years ago and then the aliens arrive. They come down to the deserts and they said, you're on our trade route now that 
the stars have moved or whatever it was, and they set the designs for their ports - your ports, however you want to think of them - next to the sea, all along the southern Mediterranean and around Arabia, so they could use the water as a coolant and then they delivered the solar panels, so many that the whole desert's been covered by them. And then the world economy collapsed once the only way to make real money was to be running the ports and getting a cut of the interstellar trade. To say nothing of the Mediterranean which is wrecked from having hot waste water pumped into it all the time. And now there's no money and no jobs in Europe. A thousand years of Western civilisation finished because some aliens drop out of the sky.'

'The will of God. What else can you say? How can you explain these things? The deserts have bloomed!'

'They've bloomed because they're covered with solar panels and because the condensation drips down. The Mediterranean is dead. Completely dead. That's worth a few plants sprouting under the solar fields?'

'But it happened.'

'They say the seaships used to go the other way.'

'Mmm. How many people leave Europe every day?'

'Too many.'

'We are happy to have them.'

'Because they do the work you don't want to.'

'This is what happens. They are paid.' He smiled brightly. 'I think you worry too much about what you think should be. Accept the world. It is a good place. You can always convert. If you are useful to us we will support you in that, and make it easy for you. No more dock work perhaps. Your future could be very nice. Ah, no, I see your face. You 
won't think about yourself. You won't see yourself as autonomous.' He stirred his spoon around his tea glass. 'It changes as you get older. You see the world differently.'

'Not everyone gets older.'

'You think that you won't? Hmm. I hope you will. It is interesting, feeling your perception of the world change. Feeling time as a physical force as well. It is not always comforting but it is interesting. I think it would interest you, if you let it.'

'Not everyone has the leisure to think about things that way.'

'Trust me. They do. Your world will soften. I remember being your age. What belief I had! In everything. In God. In the law. In progress.'

'You're saying you don't believe anymore?'

'No, of course I still believe. But the belief feels different. Not the rigid, frightening, awesome belief. Now it is more like a comfort.' He sighed. 'I am worried for you. You have a very solitary feeling. I would like you to be successful and happy here. You could be, very easily. Well. You know we are watching you, so I hope you won't be able to do anything illadvised.' The beseeching smile again.

'Is that it?'

'That's it for now. We'll talk again soon. Just keep doing what you're doing. When something happens, you tell us. Until then we'll be watching, of course, but you can just keep doing what you're doing.' He got up and opened the door and walked out. A man in plain clothes walked me back to the car and drove me back almost to the hostel. I got out on a side street. I got a kebab and the restaurant and counted my change. I kept out a two qursh coin and gave it to the old man outside the mosque. 
The next day I was at port 7 again. No one gave any sign of recognising me. We worked until 12 , then took a break to eat the lunch that was brought in to us, plastic tubs of beans with garlic and a piece of flat bread each. My partner for the day was a Frenchman called Marc.

After lunch Marc and I went back to work. After an hour I told him I needed a quick break. We sat against one of the containers already in place without speaking. The ship's hold was cooler than outside at this time of day, but the work and the lifting machines made it feel hot. My hands were moist and slippery. I pulled a heavy spanner from my overalls and smashed in Marc's head. I pulled him quickly down into the darkness of an alley and used my sweat rag to mop up the blood that he'd left. His blood dried quickly on the rag but my hands still felt sticky with his blood and my sweat. I left the body out of sight and made my way behind the containers. A distant thump shook the ground and I felt it through my feet.

I pulled open a service hatch and closed it after me. I followed the corridor straight, then turned left, then right, and a long time after that right again. I could have done it blindfolded. I was sweating heavily. I saw the door to the service room Jan and I had hidden in, marked with a tiny speck of blood just above the floor. Inside I went to the right bank of lockers, to the highest locker on the right. An Earth-made combination padlock secured it. My fingers were shaking as I entered the code we'd agreed on. 1-5-7-1. Two wires stuck out from the metal back of the locker, one red and one blue, taped to opposite sides of the locker's walls, their copper tips exposed. Another explosion outside was close enough to rattle and shake though the ship's body. I heard distant shouting and screaming and the sound of huge hatches clamping shut and then a felt a sudden weight pressing my feet into the floor - the 
feeling of the ship leaving the ground. I braced myself against the open locker and checked my watch. 13:59. I watched the second hand move around the face. Ten seconds, the slowly, so slowly, five, then two. Time for one deep breath. I touched the tips of the wires together. 


\section{The Answer \\ Niloufar Behrooz}

Author Bio: Niloufar Behrooz is a PhD candidate of English Literature at the University of Isfahan, Iran. She is a poet, essayist, musician, translator and language instructor. Her work has appeared in The Literary Hatchet, Litro Magazine, Haiku Presence, Paper Wasp, Gema Online Journal and elsewhere. Literature, languages, performative arts and culture studies are among her interests.

I woke up to an infinite darkness. Some kind of blindfold had made opening my eyes an impossible effort. I tried to reach for it but my hands seemed to be locked in place as well.

"Stop moving so much!" A low-pitched hollow voice growled. I stopped fidgeting by the sound of the cold and mechanical voice that did not bear any human characteristics.

I didn't know where I was or who I was surrounded with. All I knew was that the thing I was in was moving. I could feel a bump every once in a while. It wasn't a car though. We weren't moving on the ground or any spatial entity for that matter. It felt like a centrifugal gravity kind of movement. Was I being kidnapped through time?

The container stopped with a noisy bump. I was immediately lifted by two stiff hands.

I was put in a chair and then the blindfold was removed.

In front of me were standing seven fully grown men made entirely out of concrete. Their expressionless stony eyes were fixated on me as if they were more surprised at my sight than I was at theirs. They pressed a button and a bunch of wires flew out of nowhere and plugged to my 
forehead and wrists. Simultaneously, a huge screen appeared on the wall, monitoring my brain activity and thoughts.

"Where is this place? Who are you?" I asked as I watched my own words instantly appear on the screen.

"You are not here to ask questions." Retorted the same hollow voice I had heard in the container. He was the one with coal black eyes. They were the most uncanny creatures that I had ever seen in my life and somehow it was me who was perceived as the only strange unnatural being in the room. Was that it? Was I too human for them? Was I spotted out on the account of my excessive 'humanness?'

"You are brought here as the last specimen of your race to answer our questions." The Same voice replied as if he had heard my thoughts.

Specimen? Race? I didn't have to say the words out loud. They appeared in italics on the screen as I thought them.

"You are the last being who has still not turned concrete. And we want to know why. You must have the cure."

So that really was it. I was too much of a human for them. But I didn't have any cure. And I most certainly did not have the answers they were looking for.

"I don't have the answers you are looking for." I echoed my thoughts on the screen.

"He is saying exactly what he's thinking. That's weird!" He said looking at the screen.

"Why wouldn't I tell you the truth? I really don't have the..."

"The truth? What do you mean by that?" He interrupted me giving the word 'truth' an alien emphasis. 
"Truth is when your thoughts and words match. It's also called honesty. It's the opposite of a lie..." I heard myself sound like a dictionary so I stopped.

"But lying is one of our main principles. One shall always be deceitful." He uttered the second sentence with a more serious tone as if he was quoting from their scriptures.

"And telling the truth is one of ours." I retorted back. "It is against the will of my God to tell lies."

"Your God?"

"I call him Allah. The one and only God I praise and worship."

"I think I know the word God, sir." One of them said with an air of serene knowledge.

"I know that one too. But it is against our principles to worship a God." My interrogator said quoting their unknown scriptures again. "One shall not worship anything but himself. Every individual must praise only his own physical presence..."

His speech was cut short by the entrance of another figure at this point. This one was half concrete half human flesh covered in rags. And it was a girl! Or at least it looked like one. She had a small figure with black braids coming down to her waist. I looked at her dusty tortured face and I could still see that she had a dazzling beauty.

She whispered something to the concrete beings in a slave-like manner and threw a quick glance at me. Her eyes weren't cold and stony like the others. There was a trace of life and hope in them. I knew she was the key to this nightmarish world I was inserted in.

Whatever she said made them anxious and they hurried out of the room leaving me on the chair with plugged wires. 
The girl found a little courage at the sight of them leaving and approached me with a look of curiosity and concern.

"What is this place? Why aren't you entirely concrete like the rest of them?" I asked.

"I'm not allowed to talk to the ones they bring in for investigation." She replied looking back at the door in fear. "But I didn't think there were any non-concretes left." She added with a faint smile. "I used be a nonconcrete you know. We all did. But now it's only a matter of time before I completely turn into one of them."

"So what happened to you? Why did you turn concrete?"

"We weren't always like this. Believe it or not we used to be human too. We were good. We were pure. And then our people started to forget their goodness. They started lying, cheating, stealing, murdering and seeing no one else but themselves. With every lie their tongues turned into concrete, with every theft their hands, and with every murder their hearts. They denied everything that didn't have a physical presence; everything that was metaphysical, spiritual, or abstract for that matter. So they all started turning into 'concrete.' But it happened so gradually that no one even noticed the change. Before they knew it, they were all concrete. And then they started to change the sacred scriptures and principles. They wrote their own textbook and threw the old ones away. They turned every notion to its opposite. It used to be 'love for yourself what you love for your brother,' but now it's 'love yourself only.' They don't even remember how they used to be. They don't remember the definition of what was good and pure. Now it's either concrete or nonconcrete. That's why they see you as an alien. You have to escape or you'll turn into one of them. The new generation have started searching and asking questions about their origin. That's why they're bringing in 
half-concrete people like me to find a cure. But it's useless. It all starts with a few questions and then you're stuck here forever. The more they keep you here the sooner they concretize your brain. That's what they do to everyone who hasn't turned yet and doesn't give them the cure. That's what they did to me. I'd didn't have the answer or the cure they were looking for. So they concretized my brain and now it's spreading all over my body. It's too late for me but you have to escape and save the human race, the good and pure race..."

She stopped talking at the sound of heavy trumping footsteps.

The concrete men entered the room. One was holding a headphone-like device in his hands. He gave it to the girl and ordered her to do something with it. She came near my chair and hopelessly stared at me. I looked into her eyes and felt a deep stirring in my heart. I was ready to sacrifice myself for this little creature. I took her concrete hand in an instant. And then to my own bewilderment it happened. The girl's concrete hand turned into human flesh, spread to her arm and before she could withdraw her hand she was wholly human. Her eyes sparkled with joy.

The answer was there all along. So simple. The key to everyone's rescue. The cure to humanity.

Love. Selfless love...

The concrete men gazed at the appearance of my thoughts on the screen. 


\section{The Last Map Reader Sazida Desai}

Author Bio: Sazida Desai is a married mother of two boys from the North West of England. She works as a Press and Community Liaison Officer to a British Member of Parliament and volunteers as a School Governor. She has had several articles published by SISTERS Magazine and as well as writing she enjoys knitting, gardening and travelling.

Zeb stared wide almoned-eyed into the monitor of his garmcapsule. He felt nothing. He knew he ought to feel something. Grief, sorrow, anger, tears, something. But nothing came. Instead he continued to stare blankly at the choices in front of him. White, definitely white he thought to himself. That was what he had seen other people wear at Janazah Salahs. He wished his uncle Hamza was here with him now to advise him but he was busy continuum calling as many relatives as possible.

Zeb's mind wandered. Why hadn't Nani's body been released from the hospit, he thought to himself. He sighed and closed his eyes waiting for feelings to overcome him, but none did. It was as if he didn't know how to feel. He opened his eyes again and focused on the monitor.

'Outfit 317' he said softly into the soundport. The garmcapsule acknowledged his command and he added 'Accessory 45'. Once again, the garmcapsule whirled slowly into action.

'Perhaps you can tell me how to feel?' He asked sheepishly.

'Option not recognised' the serene voice of the garmcapsule voice retorted back.

'Almost as if she had read his mind, Khaj's face popped up on his smatch. 
'Zebby,' she said in an almost whisper.

Without even hyperpixalating the screen, Zeb could tell by her voice that Khaj had been crying, her eyes proabably red raw. Out of respect, he didn't zoom in on her eyes.

'Hey,' he whispered back, relieved that his cousin knew exactly how to behave in this situation.

She sniffled gently.

'They want you to come down' she said through her sniffles.

'Any news?' Zeb asked quietly.

'Why, did it have to happen to her?' She suddenly burst from sobbing into mild anger.

'Oh Khaj, please don't cry,' said Zeb suddenly conscious and guilty at the same time, that he hadn't yet shed a single tear for his grandmother.

'But, why? She was only 93, she was going to take me to your grading on Saturday!' she sobbed.

Zeb suddenly remembered. Nani had been so excited and proud about taking him for his grading for his black band and she had offered to bring Khaj along. She had also promised to take them out to a dessert garden after, to celebrate. The pain appeared from out of nowhere. Her unkept promise jabbed at his heart like a deep searing arrow. Nani had always kept her promises and she never lied. He hadn't known any other grown up that hadn't stretched the truth somwhere.

A tear, then another rolled quickly down Zeb's cheek at the sudden realisation that she was gone.

'Oh Khaj' he said gently into his wrist, 'what are we going to do?'

'Khadeejah!' He heard the loud voice of his Uncle in the background.

'Coming,' she replied as she turned her head to answer. 
Khaj turned back to the screen and took a deep breath as if to clear her thoughts.

'Zeb, there's something I need to tell you,' her sobbing had stopped and she suddenly sounded way older than her years.

'What is it?' he said, gently as he tried to surrepticiously wipe away one tear and then the other.

'I'm bleeding,' she said quietly peering down into her smatch.

'Where? Show me,' said. Zeb.

Khaj now raised her wrist up to the light.

'I can't,' she stated.

'Just show me, where?' Said Zeb all of a sudden worried for his cousin.

She must have seen his hand dart for the emcal button.

'No, wait!' She whispered in a harried tone.

'It's not an emergency! Don't call them!' She said.

'It's not injury bleeding, it's a period, I have my period.' She said.

'Khaj, you fool, I thought you were going to die.'

He realised what he just said and the sombre look came over before he managed to break into a little laugh. Zeb didn't know how to react. $\mathrm{He}$ had always been like an older brother to his cousin, but he wasn't quite sure what piece of advice he needed to give at this point.

'Congrates? He offered.

Khaj tutted, 'you dummy!' She scoffed.

'I'm telling you because, well because as soon as I tell my mum, that's it, we won't be able to talk. '

'What do you mean?'l Zeb could feel his heart beating faster. His mind computed faster than his emotions and he now grasped the gravity of what she was trying to tell her. That would be two of the closest people he would lose in a matter of days. 
'It might take a few hours, there's been an outage, but basically my BMB1 status will come through soon and..'

'And?' Said Zeb.

'For goodness sake, Zebby Bear, do I have to spell it out to you? I'll be baaligh, I can't smatch you anymore, we can't talk after today, my ID will be reassigned.'

'What no! Khaj, I'm still a kid, can't you get your parents to keep my ID line open.' He pleaded.

'There's no chance, my dad already doesn't like you?' She said quietly.

'Wait what!' Zeb was taken aback.

As far as Zeb knew, he had been the perfect father figure to him, since his parents had died. Quiet and demonstrative but supportive all the same. This day was turning out to be full of surprises.

'Khadeejah! This time the voice was louder. It was his uncle.

'Wait, Khaj, please don't tell your mum yet. I need you. I, I don't know, I need to keep talking to you. I can't deal with this on my own and I just have this funny feeling. Something's not right, he continued.

' I have to go,' Khaj said, interrupting him.

Before he had a chance to hyperpixalate, her face was gone from the screen.

There were shoes everywhere. And sobbing. He traversed the mountain of shoes and tried to eek out a path through what was until yesterday a normal living room. In the corner of the room, he could see that a box of iqurans had arrived and were perched respectfully onto the coffee table which had been moved to the edge of the room. Several men had already helped themselves and were engrossed in praying 
with their earshells on. There was a low murmur of takbir in the room. Zeb noticed that the digiframes on the mantle had been switched to images of the Ka'ba. Nothing like a funeral to bring out the religiousness in people, he thought to himself. He carefully made his way to the coffee table and picked up the nearest iquran. The stainless steel box was clumpy and old fashioned. It was clean, but he could tell from its dullness that it probably didn't even have last month's upgrades.

Whilst he was still wandering whether to swap it for a newer one and whether that would look odd to the men around him, a firm hand bed down heavily on his shoulder. Before he even looked round he could tell it was his uncle. It dawned on him now that his grandmother was gone, his uncle and aunt would become his legal guardians. 'Son' he said in his usual dim tone, 'I need to speak with you'. He seemed more formal than he usually did.

The white clad sea or mourners made a visible parting as Zeb was led out into the hallway. His uncle walked behind him so he couldn't see the expression on his face, but the weight of his hand was still strong on his shoulder made him feel like somehow he was in some sort of trouble. Zeb had rarely given his aunt and uncle cause to complain. His grandmother had seen to it that she was always there to advise and be the surrogate mother that his own mother, he guessed would probably have approved of.

He thought of his Nani as they walked through the house. She had taught him a great many things. More than any normal mothers, or grandmothers. A lot of it in secret. His aunt and uncle wouldn't have approved and Khaj was a willing conspirator to their many games. Another tear threatened to whet his eye as he thought about her. 
Zeb slowed down as they reached the kitchen. His uncle put his feet into his shoes which lay by the back door. Puzzled, Zeb did the same and followed him out into the back garden and down the narrow garden path. His uncle didn't say a word. Before he reached the back door which led out onto the ginnel, he suddenly stopped and turned towards him.

'Zeb, I love you as a son and you have to trust me, do you understand?' He said.

His tone was neither threatening nor friendly. It seemed to be just matter of fact. Zeb nodded silently, politely. The day was unusually clear and warm. Zeb half squinted in the bright daylight. His uncle dropped his head, it seemed as if he didn't know what to say next, as if he was searching for the right words. He looked him in the eyes. There was something there, not the sorrow of his losing his mother-in-law. Something else, Zeb struggled to make out what it was. His Nani had taught him to face read, but the emotion was so vague, it was hard to fathom. Maybe grief did that, he thought.

'We'll take it from here, sir'. A firm voice appeared to come from behind the garden wall. The back garden door swung open. A man in a dark suit flanked by two uniformed police officers stood in the ginnel. His uncle nodded at the man. Zeb looked quizzically at is uncle.

Hamza! In the distance, the voice of his aunt carried through into the garden. His uncle looked up.

'I have to get back,' he said to the suited man.

'Please make sure he is back in time for the Funeral, otherwise he will be missed'.

The dark suited man nodded.

'Come along young man', he smiled at Zeb. 
'This won't take too long. We need your help.'

Zeb eyed the ribcam nervously, the record lights were on. The man handed a smatch-stick to his uncle. You can keep an eye on him here, he said as he handed the small narrow chip to his uncle.

'Hamza! What's going on?' his aunt's voice was getting louder. It sounded like she had nearly reached the kitchen.

One of the uniformed touched the grey spectablet at his temple.

'Sir, 'he said in a hushed monotone. 'Another one down.'

'Come' the suited man appeared a little harried now.

'We have no time to lose,' the suited man said.

Zeb looked back at the house full of its shoes and its sobbers.

His uncle nodded to him and retreated up the garden path just as his aunt opened the kitchen door.

'Hamza what's going on, who are you talking to...'

Zeb couldn't make out the rest. He was being led by the arms straight into the back of a police car.

'Now then, young man,' the suited man said'.

'There's nothing to worry about. My name is Detective Inspector Williamson and I have been sent by my Chief Super to ask you for your help,' he said.

'My help?' Zeb spoke for the first time in what seemed like a very long time.

The police car didn't put its siren on to Zeb's surprise but sped down the ginnel and onto the main street. It didn't go past his house. 
'Now, I know this is a very difficult time for you and you've just had a bereavement in your family and I'm very sorry by the way,' said DI Williamson.

Zeb shrugged his shoulders, this was the first person that had offered their condolences and he didn't quite know how to react.

'The thing is,' he hesitated, like he was trying to choose his words carefully. 'We have reason to believe that you possess certain', he paused again, 'skills, that might help our force catch some certified crims'.

Zeb gulped silently. He already knew what skills they might be talking about. But how on earth did they find out. He remained silent. DI Williamson leaned in closer towards him, the faint hint of his musky afterepil weighing heavily in the air between them.

'We have intel that you are fluent in the ancient craft of......what's it called?

DI Williamson hesitated for a moment trying to recall his briefing. Zeb was about to offer his help, before the driving officer chipped in from behind the wheel

'Map-reading sir,' he said.

'Thank you Burns, yes, map-reading,' said DI Williamson.

'Now, we have some rogues, shall we say, some certified crims who are based in our hypercity who are, shall we say, causing a whole heap of trouble.' DI Williamson paused. He's face- reading me thought Zeb.

'Some of our navigational systems have been hacked and therefore compromised and so far our intelligence has uncovered only these maps. Maps that could lead us to the crims, but the problem is, as you can imagine, we need someone to decipher these maps,' said DI Williamson. 
'You mean me?' said Zeb.

'Precisely you,' said DI Wiliamson.

He smiled with miniwrinkles forming at the corner of his eyes. Zeb looked down at his lap, he was still holding the iquran in his hands.

DI Williamson leaned in a little closer.

'A lot of people depend on our systems. Schools, hospits, businesses, your friends, your aunt and uncle,' he said in hushed tone.

'Sir, one more down,' the uniform in the front passenger side interrupted.

'There is an ancient saying 'time is of the essence' and what I need you to do Aurangzeb is time senstive. I'm telling you as plainly as I can that we need your help, now, today to help track down these crims,' said DI Williamson.

Questions whirled around Zeb's head, why me, he thought. Surely there were experts in this field; historians, amateur mapologists, decoders, hacksters, why him?

The questions whirling round were quickly replaced by a smll chink of excitement. It started to multiply rapidly. Orienteering an unseen map; the thought excited him. He had long since exhausted all the maps that his Nani had given him to decipher. He had commited every last one to his natural memory.

'Where's the map?' Zeb asked eagerly.

'They're at the Metpol HQ, but I have a peedef of it here,' said DI Williamson.

DI Williamson reached in front of him and tapped the screen behind the driver seat. Zeb glanced nervously at the record light on his chestcam. His uncle would be watching. And now, he would know. He would know that someone had been teaching him to map read. Nani was an 
excellent teacher, patient and challenging, always pushing him further and further to develop his skills. Zeb had gotten better than her well before his sixth birthday. Pretty soon after that, she had started dropping out street names and and grid references. He knew the hypercity map, like the back of his hand, not even needing landmark buildings or significant roads. He took great pleasure in placing jigsaw puzzle pieces, as she like to call them and identifying where they were in reality.

That wasn't the only thing she had taught him, she had taught him how to make real fires, how to orienteer, read facial expressions and map the stars. She learnt it herself as a child and kept up her skills throughout the bans. As Zeb's mind wandered through the myriad of wonderful warm memories about his grandmother, his thoughts were rudely interrupted by DI Williamson.

'So what do you think, can you read this map?' Said DI Williamson

Zeb detected a hint impatience in his voice. He read his eyebrows. They were equally raised enough to suggest that he was not as pleasant as he had first appeared to be. Zeb shifted in his safety cocoon, this was so much more comfortable than he was used to in his uncle's car. His mind's eye ignored the three flashing red dots on the screen and homed in on a section of the travelway; he peered at it.

'Take a right here,' Zeb said suddenly as his brain deftly computed where they were on the map.

'What?' DI Williamson said in a startled voice.

Zeb allowed himself to smile a little.

'This is the point we want to get to, isn't it?' Said Zeb pointing to the flashing dot. 
'Yes, but,' DI Williamson seemed genuinely flabberghasted.

'Sir?,' the driver policeperson said, turning around.

DI Williamson looked Zeb in the eyes and then turned to the driver policeperson.

'Permission to Drive Watkins,' he said in the same authoritative tone he used to address the uniforms.

'Yessir,' Watkins acknowledged.

'Go to manual,' Watkins spoke firmly into his soundport. He tapped his right temple before placing his hands on the steering wheel which moved into position right in front of him.

Zeb's heart began to beat wildly. He gripped the iquran tightly in his hands, he had never been in a person driven vehicle before. He prayed a silent durood in his mind. God save me.

Watkins turned the wheel towards the left just as the audible signal came on. Zeb had heard these before, just never this loudly and never from the vehicle he was actually travelling in. Zeb's safety cocoon swayed with his body as the car jerked around a bend.

'Left here,' Zeb pointed as they came up to the next junction. All the other cars on the road were temporarily immobilised. He had been in cars before under temporary immobilisation, but never in one that could move whilst all others stopped dead in their tracks.

'So they've not managed to interfere with the TVP systems,' Zeb asked.

'Just concentrate on the road, son,' replied DI Williamson. It looked like he was going to say something else, but thought better of it and tapped the map screen.

'What does else does the map tell you?' He asked.

'Nothing, it's a map, it can't tell you anything else apart from the locations of this dots right here,' said Zeb calmly. 
'Are you sure? No other messages? What do all these lines mean, are they ancient scripts?' DI William said. His voice grew impatient. Zeb gave a little snort, then quickly adjusted his smile.

'No sir, it's just like a, a visual representation of what's on the ground,' said Zeb.

'Hmmm,' said DI Williamson, 'they said you were a smart one.'

'Over this bridge, here.' Said Zeb. He glanced back and forth between the front windshield and the map screen. Zeb was unfamiliar with this part of the city. He was relying entirely on the map.

'Take a right at the end.' Zeb said, his own voice getting louder and more impatient.

'There is no right at the end,' said Watkins.

The siren was still blaring around them, the one or two two vehicles on the road around them were still immobilised. The drivers peered into the police car windows.

'There is according to this map,' said Zeb still glancing between the map and the windshield.

'Take a right,' Zeb shouted.

Zeb looked at the front driver screen. The satnav showed no road after the bridge on the right. He looked out of the window. The sun shone unusually bright onto an area that was relatively run down. All but one of the electric billboards were flickering with ads at least three weeks out of date, he noted. There was a small narrow electric gate. The driver slammed on the brakes. Zeb shuddered, he had never experienced an emergency stop before. He looked at both of the uniformed officers then DI Williamson. None of them flinched. He guessed they must be used to it. He made a mental note to look up police training after he was done here. The driver side car door opened, Burns got out and waived the 
slim shiny multi-techband on his wrist across the panel at the side of the gate. It bleeped for a few seconds and then flew open. The officer jumped back in the car and the engine started again as he got in the seat.

'Wow!' Exclaimed Zeb under his breath. They really could get in anywhere. He looked at DI Williamson who smiled smugly at him.

'Right, now where bright spark?' said DI Wiiliamson.

'Umm,' Zeb looked again at his screen. There appeared to be a myriad of travelways past this point before they were anywhere near the dotted target. Burns tapped his temple and almost instantly the distinct sound of martial hovercruisers sounded in the distance.

This must be one bad crim thought Zeb. Police sirens blared from the direction which they had just come from. Zeb tried to concentrate on the dot; giving concise directions as they sped through a narrow network of travelways. Before they had reached their destination, the car screeched to a violent halt, throwing Zeb into the side of the car, the safety cocoon, yanked his whole body across the back of the car as it took the full impact. Zeb felt sick. Two manual stops. Wait till he told Khaj about this adventure. She would be so jealous, she had always been the one for the thrills and spills.

All three policemen unharnessed their safety cocoons and jumped out of the car, chasing what looked like a man running in the other direction. He was a little older than the officers, maybe in his seventies or eighties and Burns wrestled him to the ground. Zeb could feel his stomach churn. Four cars and two large vans had turned up. Zeb stay mooted to his spectator seat in the back of the police car. The other cars screeched one by one to a rough stop and uniformed officers poured out of the cars surrounding the man. 
DI Williamson stood over the man who was being cuffed and cautioned. He motioned to the officers towards a tall polycarbon building, its windows having lost their anti-solar glare sheen. The officers pounded the ground as they ran toward the building. DI Wiliiamson followed. Zeb looked at the screen. The dot was in the opposite direction to the building. It was a decoy. Zeb struggled with the cocoon belt for a few moments before releasing the catch.

'Wait,' he shouted, 'you've got it wrong. It's not that way!'

Burns was still grappling with the detainee when both men suddenly noticed him. 'Get back in the vehicle.'

'No wait, you don't understand,' shouted Zeb back surprised by the conviction in his own voice.

'Get back in the car!' Burns shouted louder.

Zeb quivered. The nausea that was rising in his stomach grew stronger as he got on his feet. He felt rooted to the spot. The detainee stared at him wide eyed, his wrinkles were deeper than any he had seen before. They were natural and engraved deep into his weathered face. The man looked at Zeb's white clothes and then met his gaze. A look of almost recognition appeared on his face.

The man shouted at him in Urdu. Zeb scrunched his face as he tried to figure out what he was saying.

'Your mother!' He cried.

Zeb looked perplexed.

'You know, you know where she is, go, go now.' The man shouted as Burns wrapped a strong forearm around his neck. One officer kneed him hard in the stomach. The nausea was overwhelming, this last assault on Zeb's sight brought forth what little meal he had eaten that morning, propelling it out onto the gravelly ground. The smell 
immediately assaulted his senses and he wretched again drawing more liquid from his gullet.

'They killed your Nanimaa', he carried on shouting as the officers grappled with him landing another knee into his stomach with a dull thud.

'Get back in the car,' Watkins shouted.

Zeb looked on the ground at the pale liquid vomit and steadied himself. His smatch beeped. The ground spun a little and as things came sharply again into focus, he stood up, took a deep breath and scuttled back to the car. He looked at the screen again. The dot was still flashing. The adrenaline under his skin was palpable, his heart beat wildly. He had never disobeyed an adult in his life yet and yet his Nani's voice reached him from wherever she was. 'People always lie, trust your own truths.' He had never known what that meant. He looked down at the seat. The iquran lay there. Without another moment's hesitation, he scooped it holding it tightly between his fingers. Glancing back at the three men, he saw Watkins put his smatch up to the older man's temple who fell limply into his arms.

Zeb took a final look at the screen, two left, three right, one left, back corner, that was where the dot was, that was where he needed to get to. Something inside told him he needed to get there before the police swooped the whole area. This must be the instinct she always talked about. He scurried out of the car on the other side and closed the door gently behind him lowering his body as she ran as silently as he could, weaving his way around the travelways. His mind was still hazy from the violence he had just witnessed. His legs took him in the direction along the route he had mapped out in his head. 
This is it, he told himself, panting for breath as he reached an inconspicuous doorway. Zeb stood in front of the monitor which scanned his pupil and to his surprise, slid open on first blink. He had never entered a room on first blink before. His pulse quickened. Zeb slid inside the cold dark room. The glass doorway closed silently behind him.

The room was bare except for an old fashioned table with a glass top and steel legs. He tapped the table top, just to make sure. No response. It was dead. Zeb scanned the room. Why hadn't the man given him something else to go on, he thought. There were footstep noises nearby outside. Zeb scanned the room. It was totally empty with a dank smell. He went back again to the doorway he had come from, before his eyes picked out an anomaly from the far side. Scrabbling across, he noticed a slim piece of cream coloured chip at his eye height. He prized it out gently from a little gap in the wall. It was a folded up piece of paper. It was crisp and heavy and neatly folded. He unfolded it quickly as he heard more footsteps nearing the doorway. There was a heavy print of full words printed with real ink on the smooth paper. Zeb traced the print with his fingertips. Times New Roman he whispered gently to himself, impressed that he had recognised the print so quickly from his knowledge bank of type fonts. He slowly read the words, they were unfamiliar and took him longer to decode.

'One Hundred and Two, Three,' he read slowly.

Zeb racked his brains. The footsteps outside were heavier now, almost a chase.

'Sir, illegal coding, we can't get in,' an unknown voice came from beyond the doorway. 
'Violation granted,' another voice commanded. It sounded like DI Williamson.

Zeb quickly folded the paper and pushed it back into its narrow hiding place. He scrambled back to the other side of the room, blinking into the monitor by the side of the door. No sooner as his eyes opened, they were met with the bulging veined pupils of DI Williamson. He looked behind Zeb at the empty room, circled his fingers in the air as the officers behind him drained into the room.

'Full sweep, 'he said authoritatively as he placed his fingers from one hand to his temple and the other firmly on Zeb's shoulder.

They walked silently back to the car. Williamson had noted the faint line of Zeb's digestive juices along the front of his top. He said nothing as he led Zeb to an unmarked car and cocooned him in the back, whilst he got into the front.

As they drove past the house, there was an air of disquiet. The sun was getting hotter and brighter. There was no-on outside. Williamson drove past the house and parked up some distance away. He walked Zeb the short distance along the street to his house and remained watching outside until Zeb was in the house.

Zeb took the stairs two at a time and fled to his room.

One Hundred and Two, Three. He repeated the words over and over so that he wouldn't forget them. The house was as it had been. He was about to go his grandmother's room to ask her, before he remembered she was not there. The searing pain in his heart returned. They had killed her that's the man had said. Thoughts flew around his head, his head spun. The now familiar nausea started to build in the pit of his rumbling stomach. He sat down on his bedpod, trying to make sense of 
everything. He looked at his hands. He was still clutching the iquran, his knuckles near white from the tight grip.

Zeb suddenly had a thought. He deftly entered the numbers manually into the search screenpad. 102:3.

The ayah it brought up was strange and unfamiliar, he immediately tapped the translate button.

'Until you visit the graveyards,' flashed up on the small flickering screen.

Zeb sprung almost involuntarily off his bedpod. He looked out of the window and down the street. Williamson's car was still docked a few homes away. He watched silently for a few moments. The silence. He realised what it was. The funeral. Zeb inhaled sharply. All the men had left without him. That was what the quiet was. He should have been there. No-one had waited for him.

His smatch flickered with a ream of selecticons. It was Khaj. She was impatient, near angry, he could tell from her recklessly chosen sequence.

'BR2 now,' she whispered into her screen.

Kaj's face was almost as red as the selecticons she had sent him.

'I need your clothes, now!' she said.

Zeb frowned at her.

'Don't give me that look, I saw you leave with that man. C'mon, I really need a switch-up now', she talked faster than she normally did. Zeb thought to himself.

'Stop thinking, you're always thinking, never doing. Now stop thinking so much and switch-up. For goodness sake, it's not like we haven't done it before,' She hissed. 
'Khaj, I just think, I don't know, I think we're being watched and there's all this other crazy stuff going on...' Zeb trailed off not knowing where to start. They both jumped a little when they heard the voice of women chattering outside the bathroom.

'Quick we haven't got time for all that right now. I'll explain later,' she said.

'Khadeeja!' Her mums voice came from downstairs.

'Actually, thinking about it, I think I could do with a switch-up,' said Zeb.

'Back in your own clothes by maghrib latest, yeah?' said Khaj.

Zeb nodded.

'Smatch me when you're done, Ok, turn around,' said Khaj.

They both undressed quickly and flung their clothes over each other shoulders.

'Have you grown?' Zeb remarked as he pushed the tag at his cuff.

'This top has resized three stages, it was only one last time,' said Zeb.

'No, you've shrunk,' retorted Khaj as she pushed the small square tab at her wrist.

'Don't mess with the style settings,' said Zeb, 'it took me ages to get it right.'

'Ugh, so vain,' said Khaj as she pushed the tag at her cuff.

'You've definitely shrunk,' she said as the trousers lengthened to cover her ankles.

Zeb has about to eye scan the door.

'Wait!' Khaj put her hands up to cover his eyes.

'What?' said Zeb.

'Colours?' Khaj's eyebrows were raised.

'Oh yeah,' Zeb looked down at his perfectly fitted outfit.

'What do you call this, just so I know for later?' 
'Panther Pink 800,' said Khaj.

'Panthers aren't pink,' Zeb exclaimed in a hushed hiss.

'You won't understand, its vintage.' Khaj replied.

They simultaneously pushed the tags at their cuffs and in an instant, Zeb's outfit turned bright white and Khaj's a perfect Panther Pink 800.

'Wow' said Zeb, I'll try that colour someday,' he smirked.

'Shh I'll go first, lock it behind me and don't come out for until at least a couple of hundsecs,' Khaj whispered loudly. With that she scanned her eyes on the monitor and disappeared down the corridor.

Walking quickly downstairs, Zeb was thankful that Khaj hadn't activated her usual sweet pungent scent function on her outfit that day. He guessed that she hadn't done, out of respect. Either way no one would detect that they would have switched clothes, except perhaps for his aunt. It was easy to avoid her in the crowded house today. There were still many women downstairs. She was much too busy and distraught to notice anything.

The day was unusually bright. Pure sunlight was a rare occurrence outside of Summer and the smog had somehow lifted as if a great blanket had been lifted out of the sky to reveal colours of blue, the likes of which Zeb had rarely seen. The Summer blues were deep azure, this blue was light and soft.

Zeb reached the cemetery just as the last of the mourners were leaving in their cars. Some men were stood chatting in the car docking station. Zeb hid out of sight until most of the cars had cleared the car docks. A strong hand suddenly came down on his left shoulder.

'And what are you doing here?' It was Uncle Hamza.

Zeb shuddered. 
'You left without me!' He said quietly. It wasn't often that he addressed his uncle.

'Sorry, son, I had no idea when that Polson was going to bring you back, you know how it is. Come on child, I'll take you to her. Say your goodbyes properly,' he said as he placed an arm around his shoulder.

Uncle Hamza led Zeb to a small mound of fresh parched soil. A lumpy knot started to form in Zeb's throat.

'Uncle, please could I stay a while?' Said Zeb.

His uncle looked at him pitifully. Zeb thought he read his face perfectly. His uncle's face had always been quite easy to read.

'Of course, take your time. I'll just go and tell the other brothers we'll be late back. I need to sort out a lift for them all.'

He headed back in the direction of the docking station.

Zeb turned back and faced the soft mound.

'Nani, I'm here,' he whispered, half hoping she would reply. Not knowing what to expect, he dropped down on his knees and raised his cupped hands in prayer. Please make my Nani go to Jannah he pleaded with all his heart. The grief overcame him again and tears flowed steadily from his eyes, streaming quickly down his sun starched cheeks. He heard his uncle's footsteps behind him. He carried on praying.

A thought disrupted his next prayer. The sound of footsteps were distinctly his uncles but they weren't coming from the direction of the docking station. It was at least 50 degrees away from that direction. With hands still raised in prayer, Zeb slowly swivelled his pupils in that direction.

There were trees and shrubs and he caught sight of the bright sunlight illuminated something which sent the reflected light rays back to him nearly blinding him. Zeb lowered his face closer into his cupped hands 
and whispered into his smatch, 'Hamza Adam 6597, BP, calender, last message.'

The smatch responded instantly '160/90, abnormal raised, stress level 7.5 , funeral 1400 , finish him.'

Adrenaline kicked in as Zeb swung low, side stepped to his left and pushed his uncle from behind onto the mound. He disarmed his uncle's smatch and flung it across the ground. He had practiced this move hundreds of times every Saturday morning for at least four years. Never had he imagined he might one day use it on the one man he trusted and loved most in the world.

His uncle was dazed. Not unconscious, but dazed and unsteady, half crouched on the mound. Zeb didn't know what to do next. Tears were still streaming down his face and his body was pulsating furiously with blood pumping to his extremities. His smatch bleeped uncontrollably. 'You planted that note for me, didn't you?' Zeb's shouted at him as he took him in a restraining hold.

'What note, I don't know what you're talking about, let me go,' he said as he struggled.

'You're strong for a small kid,' his uncle said.

Zeb strengthen his grip even tighter, his rage growing stronger.

'You told me to come here alone didn't you, you knew I would come,' Zeb demanded.

'No, he didn't, I did.' A voice said.

Zeb swung his neck round abruptly. He thought they were alone.

It was a woman's voice. Her face was covered with an eniqab. She tapped the side of her head and the eniqab disengaged. Her pupils locked onto Zeb's. He knew these eyes. They were identical to his Nani's and his aunt's. Her eyes were glazed as if holding back tears. Her face 
was more weathered than his aunts, but the shape of the eye sockets and angular cheekbones were the same. He recalled the one digimage he had of his mother and there was no mistaking the woman standing above him now.

Zeb was rooted to the spot. His throat felt dry. Just like earlier, he didn't know how to feel about this. He had never missed his mother. He had never known her. But he had fantasised about her since before his first memories.

In his mind, she was beautiful and kind and lavished him with love and kisses. The woman before him was stern, cold, he wasn't even sure if it was his mother. She grabbed him roughly and quickly by the wrist.

'Come you are not safe here,' she said.

Zeb had already started to release his grip on his uncle. A sharp implement appeared from out of nowhere it seemed and seared his mother's hand. His Uncle's hands shook as he looked at the bloodied blade. With his spare hand he knocked Zeb back onto the mound. His mother and her uncle tussled on the ground. The sight of the fresh blood made Zeb feel woozy. It was redder than he had imagined it.

'Get it together,' he told himself as he tried to get to his feet. He remained rooted to the spot, his whole body paralysed. There was residual heat under the back of his smatch screen; it had been shock activated.

'I can't move.' Zeb tried to shout, but his voice came out weak.' 'Aurungzeb!' his mother shouted as she grappled with his uncle. Zeb watched them, his pupils locked now in a position only to watch his mother and his uncle, each one struggling to gain control. They were both bare-wristed. His mother was slight in body and shorter than his aunt. His uncle was robust and towered over both mother and child. 
'You traitor,' he heard his mother say.

Zeb tried to move his fingertips, it was no use. The full body shock was arresting and lasted fifteen minutes, long enough for the administrators to seize him. There was nothing he could do. He could still feel his body on the mound. He at once felt bad for laying on the mound of his dead grandmother.

Forgive me, he thought to himself. He tried to shut his eyes, but his eyelids were locked.

'Go,' he tried to say the word out loud but his tongue was paralysed, he knew his mother would not leave him here alone and the police would be here soon. There was no way out of the dead lock shock.

He thought, why had his thought not been suspended. He had seen it in hundreds of movies, thoughts were suspended during a full body shock. But he was thinking, still thinking. The shock had so far failed to disengage his neural pathways. Think, think. The body shock could only be disengaged once the administrator unlocks the hold or if the wearer dies.

Zeb concentrated with all his mental strength on his BP training. He had never managed it so low as to fool his smatch into thinking he was clinically dead. He focused what neural energy he still had control over. His mother and her uncle were still grappling. He heard grunts coming from their direction. A low bleep emitted from his smatch. It was working. Another, he recognised the distinct sounds, he knew because he had programmed each one. This was it, the next beep should take him lower. He concentrated hard.

The low bleep turned into a constant hum and with a full body jolt, Zeb gained control over his muscles. He immediately sprang into action, scrabbling to his feet, looking around for his mother. 
His uncle's lifeless body lay on the ground, metres from the mound. More fresh blood had spilt onto his bright white clothes and the already rust red ground.

His mother lay wounded to the side of him. Zeb helped her off the ground and she limped toward the trees.

'This way, get rid of your smatch,' she panted at him.

'Where are we going, you need help,' said Zeb.

'I'm fine, just get rid of that thing quick, they are trying to kill you,' said his mother.

'But why?' said Zeb trying to avoid looking back in the direction of where his Uncle lay.

'Because, you know too much,' his mother said.

'But I have to warn Khaj,' he suddenly remembered as he looked down at his wrist.

'Warn her about what?' His mother asked.

'We switched up,' said Zeb quietly, his head bowed.

'What?' His mother exclaimed.

Zeb quickly unlocked the smatch from his wrist.

'Khaj' he called into the tiny screen.

'It's me.'

'This account has been disengaged.'

He tried again. 'Khaj, no tricks,' he said furiously into the smatch.

'This account has been disengaged.'

He looked at his mother.

A solitary tear ran down her cheek. Her face was unfamiliar to him, but the look wasn't.

'We have to keep going.' She said as she picked up her pace and carried on walking. 
'I can't go on.' Zeb said as he fell to his knees. Tired and weary.

'Aurungzeb, now listen to me. We need you and we need you now. I know you have a lot of questions and not a lot is making sense right now. But this is the time that we need you to help save us.'

'Save who, from what.' The energy had drained from his tired body.

'I don't know what the polsons have told you, but there's an army out there who want to quietly obliterate us, me and you, the higher thinkers. Our ancient skills are a threat and we are being hunted down. That includes you.'

'For what?' Zeb looked up and squinted as the sun had managed to filter its way through the trees.

'For their defence systems,' she said as she stopped to look at him.

'You see; they have all the tech but not the human skills to exploit them to their full potential. They don't understand written language, they can't compute, they can't read maps, they don't know our ancient English scripts, they don't know how to read human emotions naturally, they don't know their body rhythms, our human race has lost its imagination, and there are only a few who survive who dream and think. You are one of them, and they feel threatened.

We are not the enemy. They are.' Her voice was controlled, her eyes bright.

'So why did you disengage the sat navs?' He said.

'We didn't.' She said in the same controlled tone of voice.

'Don't believe everything you're told, didn't Nani teach you anything?' She said with a hint of a wry smile.

Zeb was taken aback by her criticism.

'You need to learn to toughen up.' She said as she pulled him up from off his knees. 
'Where are we going?' said Zeb.

His mother smiled fully at him now, her face glowing from the dappled sunshine on her skin.

'To release your father,' she said.

Zeb looked back through the trees towards the mound of his Nani's grave and prayed a silent durood for her. Thank you Nani he said quietly to himself. He smiled as he tossed his smatch into the long grass and wiped the tears from his cheek with the back of his hand. 


\section{The End of the World \\ Nora Salem}

Author Bio: Nora Salem is an Arab-American EMT who moved from the Mideast to the Midwest. Her favorite scifi authors include Sandy Williams, Sharon Lynn Fisher, Sara Creasy, and Lois McMaster Bujold. She loves talking science and culture and breaking ceilings. Her favorite foods are kibbé and sushi.

It was silent but for the crunch, crunch, crunch inside his head. Nouari Tarkou stared at the yellowed cereal box. Trigo con Chocolate, the Frosted Flakes imitation Basima Beznawi and Ahmed Tarkou bought him when his younger incarnation whined. He had never stopped loving Trigo con Chocolate, even despite his snag-toothed nephew singsonging that only children ate cereal. Nouari still ate Trigo con Chocolate, long after his nephew and parents were dead.

He glanced at the clouded windows as if he could see the street beyond. Almost dusk. Perhaps he would scavenge today. Creaking like an ungreased hinge, he unfolded himself from the card table, set his single spoon on the worn counter, and caught up his rifle; he had seen chacal yesterday. At least I wait until the pobres desgraciados no longer need their things.

The oiled door to his apartment opened without a sound because the chacal could hear long distances these days. Nouari descended the stairs with the rifle braced against his shoulder, sighting down the barrel at every corner. Two landings later, he cracked open the building door and squinted through roaring sunlight at Rambla Nova, quiet as space. As the heat blanketed his shoulders, he looked at the roadside 
trees, leafless, dry and brittle. The birds had migrated north a long time ago.

He hated this part. Setting his jaw, he shuffled into the light and picked up his feet as he stumbled on cracked pavement. Yil'an-! He should focus. Why did he still expect to see the Rambla Nova of his youth, the artery where he had once bought melindros and pedaled his bike until ten o'clock and the shouts of pedestrians stopped him?

Nouari lowered his rifle to wipe his brow, and his palm came away wet. Damn heat. He raked back the short, curling hair above his forehead and glanced up at the balconies stacked to the sky, every one potential cover for bandits. I should have left the city.

"You should have left the city, old man."

Nouari stiffened. He started twisting towards the mouth of his apartment building, but a hand gripped the barrel of his rifle.

"You should have left Spain." In a shirt that read "Salvad España," the man standing in his doorway had curly hair like Nouari, only it was brown instead of gray, and a smile grim and cunning as a jackal's. His steak knife grazed Nouari's throat.

"I'm not alone," he killed Nouari's hopes of struggle.

"I have food upstairs."

"I know."

A silence as the chacal allowed Nouari to digest this, and Nouari's heart labored under a boulder of fear as he realized the chacal might not want goods. This was much worse.

Nouari kept his expression level, but his voice shook. "What do you want, then?"

The bandit nodded. "Your gun."

"My gun?" He shouldn't protest. "There are guns for days." 
"Not enough." The chacal's eyes were hard; he was impatient.

He lied, Nouari knew. It was food, real food, in short supply. Guns didn't require rainfall.

"It's my only defense."

"Much good as it did you." Was the chacal amused? The bandit's shoulders were still tense in confrontation. What if Nouari were a threat? For a reckless moment, he thought of fighting.

"I've survived this long," Nouari muttered, releasing the gun. "You'd steal the last defense of an old man?"

That light crept into the chacal's gaze again, as if he were amused. "I have a feeling you're old when it suits you."

The villain was relaxed now that he had Nouari's weapon. Now was Nouari's chance. "What's your name? Where are you from?"

The chacal stiffened and thrust Nouari ahead of him on the street. "Too many questions. Move."

"What's the harm? There are no police anymore. If you're taking me somewhere, we should get acquainted first." Despite Nouari's brave words, his hands trembled. What else could the chacal want? The other man didn't respond to Nouari's questions, brandishing his knife in Nouari's peripheral vision, ostensibly to tuck it back into the rope around his waist. Adrenaline had caught hold of Nouari. "Is this what we've resorted to? Great humanity? All it took was a drought?"

For his troubles, the bandit spared him a glare and pushed him by his shoulder past crumbling hotels and restaurants. It hurt to see them as much as it hurt to see the bandit's damned shirt. "You lied when you said you weren't alone."

"I'm not." He pointed. The pillars of the ancient Roman forum rose from the horizon, another ruin. He could hear the waves crashing against the 
Museo Nacional Arqueológico in the distance, become a sea wall after the oceans rose, and it was an effort to stop his hands from covering his ears. "What kind of game is this?"

The bandit stopped under an arch and wrestled his knife from his rope belt. "Getting rid of you."

Nouari threw up his hands. "Wait-!"

The other man hooked his chin. "Go. Follow Carrer Major north."

He was letting him free? Nouari wasn't sure what lunatic impulse inspired him to ask, "You want me gone? Why? What threat does a man like me pose?"

"None at all," the chacal said softly. His raised brows said the rest. None at all if I want to kill you. Then he saw them: men, climbing like ants into and out of the amphitheater. Now he understood the bandit's meaning. One of the ants carried a big black box.

"Wait! I won't survive out there!" Nouari blurted.

The chacal showed his teeth, snarling, “Are you senile? Haven't you caught on, old man? We're not in the protection business. We're in the take-your-fucking-shit business."

Now he looked hard-eyed as Nouari had first seen him. Nouari swallowed. "I'm clever, I'll help you." When the bandit's lids fell, and he twisted the knife's handle, Nouari rushed on, "Do you know how to use that radio?"

The bandit halted, face naked with shock and hope for a moment, and Nouari knew he had caught him by the gills. "What radio?" the man recovered, shuttered.

Damnit. "I was a member of Asociación de Ingenieros Eléctricos. Before the Drought."

Nothing. 
Nouari clenched his teeth. "Do you even realize what you've found?

There's no other means of communication in northeastern Spain, perhaps all of Spain. You need a generator to use it. Do you have one?"

"This old bastard giving you trouble, Doctor?"

Nouari's gaze flashed to a pillar ahead of them, where a man emerged swinging a machete. He wore the same tattered Pepsi Cola t-shirt that Nouari and the other man did. Then the bandit's words sank in. "Doctor?" he accused.

"No," the doctor threw over his shoulder to his comrade. "No trouble. Throw him in the tower."

Nouari's heart sank as the other man turned his back on his protests.

He woke with a splitting headache.

"Don't take offense," someone was saying, "it was easier than dragging you along unwilling."

"I'm still unwilling," Nouari muttered past the pain swarming the back of his skull. He groaned as he raised his head. A wall of pitted brown stared back at him as he observed a room made of stone that was nonetheless sultry with heat. The bandit's comrade crouched peering at him.

"Where are you from?" he asked, cheerfully ignoring Nouari's comment. "My name’s Hassan. My family's from Ketama."

Nouari raised a brow at this bald pronouncement. "Ketama? You're a hash dealer?"

"I was," he shrugged. He flourished a hand at the ruins around them.

"This is Ketama now."

For a hash dealer, the man was insightful. They had no mountains, but Hassan was right, the rocky field Nouari could see through the casement 
window resembled northern Morocco more than Tarragona now. He slumped against the wall.

“Too bad it's not useful here. Hash," Hassan explained.

"Hassan, go patrol."

Hassan rocked on his heels before bouncing to his feet, saluting Nouari.

The doctor entered as he left. "He killed his own cousin."

Nouari shivered. "These are the kinds of people you truck with?"

"Sometimes. I don't have a choice. I tried to protect you from them." The

doctor scrubbed his face and leaned against the dusty ocher wall. He couldn't have seen more than thirty-five years, but he looked haggard, frown lines deep trenches. Banditry ages a fellow.

"What kind of a doctor are you?"

"I'm not a doctor," he sighed. His sneakers scuffed the dirt. "They like to call me that. I've a botany PhD. Anyway, do you think doctors are angelic?” He was annoyed.

"A botany PhD?" Nouari repeated, owlish. Allah saedna. A botany PhD. marshalled a bunch of killers? It's just as well the city's vacant. "Did you bond over a mutual love of plants?"

"Never mind. I want you to try that radio."

"What radio?"

The botany PhD wasn't amused. He straightened from the wall and crooked his hand as if Nouari were an errant child. "Come on."

"I can't resist a field trip," Nouari said, following, to freedom.

"Are you going to give me a name? Botany PhD is too long." Nouari stood crouched over the radio he had glimpsed outside. A shortwave! Where did they find it in this tourist town? The generator sat waiting patiently next to it. Nouari had already looked inside. 
The bandit flushed. "Marc Oliver," he said, upturning a crate for a seat with the same speed that he twirled his knife. Had he used that knife before?

"Marc Oliver," Nouari affected an accent on the surname. "Sounds like an actor. You didn't ask, but I'll tell you. Nouari Tarkou. There. There is still civilization at the end of the world," he said, while deciding whether he should give the radio into these crooks' hands. He couldn't very well smuggle it out. He'd need their advice to do that. "Why didn't you evacuate with the rest?"

"Why didn't you?"

Nouari said nothing.

Marc saw him gazing out the window at the waves rushing through the former Hotel Alicante. "It's a nice view, isn't it?"

Grisly, more like.

“Can you fix it?" Marc's brown eyes were earnest. Now Nouari could believe he had been a student. He had forgotten to intimidate for a heartbeat. When Nouari hesitated, he demanded, "You are an engineer, aren't you?"

"You've been around these people too long." Nouari sank to the floor. "Yes, I can fix it. I have a list of things."

Marc came to his feet in a flash. "I'll get them."

"Don't get your hopes up," Nouari felt compelled to say. He shouldn't pity these men, even if he couldn't resist his own hopes of freedom. Perhaps it was too much pressure for a radio.

Marc recovered himself, scowled.

That's better.

The local auto shop and cars had been scavenged, but even so, the men found a carburetor in a day. Fresh petrol took longer, and Nouari 
counted every day, unnerved and attempting not to show that he was unnerved by his housemates swapping blood-curdling bedtime stories such as that amusing time Jamel killed his rival outside his own warehouse.

"There are no prisons at the end of the world," Marc shrugged when he complained. "Don't you believe in rehabilitation, Mr. Tarkou?"

"They don't seem repentant." Nouari glanced at the men frolicking like children under the sun. Perhaps he should find them when they weren't at play. "Do you have any more pajitas?"

Marc's grin stretched to his ears. "This is your third bag. I feel like your supplier."

Nouari glowered as he snatched the chips from Marc's hands, ketchupflavored just like old times. They were the only spot of joy in this pit. "Don't make that joke here."

"Nevertheless, those cretins need to eat too."

Nouari flushed with guilt. "Why didn't you tell me I was having too much?" he barked.

"Senor Old Man, we have your petrol!"

Marc and Nouari straightened like ropes pulled taut, but the bandit was already preceding them down the stairs. An hour later, the crew huddled around Nouari as he bent over the radio, scanning channels.

"All I hear is static, old man. Just as I said," one bandit turned to his fellows, who nodded and spat vulgar aspersions on Nouari, radios, the sun, and everything else. Nouari remembered the man's name.

“Hugo, isn't it? This is a waiting game." The men's faces fell until he went on, "We'll have to assign teams to monitor the channels around the clock." 
That sounded sufficiently important or different from their daily drudgery that they elbowed and jostled forward with raised hands.

"Senor, I have excellent hearing!"

Nouari intervened before the blood bath, "All of you will have a turn! We still need a perimeter watch too. Although what we are watching for, when the foxes are all gathered here, I am not sure," he added under his breath. The band had already explained that they'd wanted him driven from Tarragona so that he wouldn't alert their "enemies," but he had yet to meet any other humans.

"The Russians!" The man did have excellent hearing.

The Russians were much worse, they all agreed, nodding. Nothing raised his brows anymore. Nouari supposed he ought to be grateful they had volunteered to listen to the radio, but two weeks later, the men returned to him with ominous scowls.

"We haven't heard anything, Senor."

"Be patient," he said as his teacher used to say to him when he got a papercut.

"We have been. Perhaps you are not telling us everything. Perhaps you want our radio for yourself. Perhaps you lied about the radio so that we wouldn't kill you."

Why did they have to bring that word into this? Nouari could feel, like hounds trained on a whistle, the men crowd forward at that, surrounding him with once-affable eyes gone narrow. Something fell over his shoulders. The shadows seemed dangerous now, omens.

"What is Senor Old Man going to do to you? Stop harassing him, you thugs. Leave him be. Get a move on, yallah," Marc dispersed them.

"All right! Guy learns a word, and he thinks he's special," one of them muttered as he passed. 
Nouari released his breath. "That won't keep them forever."

"Neither will I." Marc was realistic about his power over the bandits. "We have to be gone before that. What?" he asked of Nouari's raised brows.

"Well..." It was hard to explain. Nouari gestured. "It's just that... We're at the end of the world. We're the leaders. Aren't we recreating society here? Should we be abandoning people...?"

Not so hard after all.

Marc threw up his shoulders. "I'm too old for that idealism. I'm just trying to survive. I was just hoping to find people doing better than this."

"Me too."

"You were just surviving too," Marc reminded him, and Nouari couldn't disagree. When had his expectations risen?

Marc started for the door. "Keep trying the radio."

The bandits sank back into routine, joking now and then about Amrika saving them. Nouari- Nouari wasn't sure why he was disappointed. He couldn't decide whether it was safer to return to his survivor's mindset or nurture the ember of hope the radio had kindled. If he were staying, perhaps he should stop holding himself aloof and reconcile himself to his companions. They hadn't killed anyone since he'd arrived. Marc said it was his sublime influence.

He began to worry that the same summer storm surges that had damaged the cell towers would rise to kill any radio signal.

Then one night he heard them. Beeps, like in the World War II movies, scattered and interrupted by noise. Nouari clutched the table because he would knock the radio or something in his excitement.

Marc arrived when Nouari didn't show for breakfast. 
"Are you sure?" he asked.

Nouari nodded, too ecstatic for words.

"What do we do about it?" Perhaps he hadn't expected the radioing to bear fruit. Now the day had arrived, Marc was bewildered.

"I don't know," Nouari murmured. Should they tell the others?

"Translate it." Marc was more practical.

"I don't know if I remember."

"You should probably use this then." Marc tapped the guide taped to the radio's left side and laughed at Nouari's glare, but Nouari's scowl vanished when the beeps began again.

"Quickly!”

"Yallah!" Hurry! Nouari set pen to paper, consumed by a siren song of beeps more beautiful than any Um Kulthum ballad. He didn't mind Marc jumping around him, he could hear his own heart galloping as he imagined humans, civilization, food. After a few characters, Nouari marveled, "It's Arabi."

...SAMANEEN, MIN FADLKUN JAWEBU...

"'Please respond.' What should we answer?"

In the end, they decided to ask the most vital question in a Spain vacant and a Europe preoccupied with floods or droughts, WHERE ARE YOU?

They waited for an hour or more. Nouari chewed off his nails. Twice Marc told him to breathe more quietly.

MOROCCO.

Marc and Nouari exchanged a glance, each for different reasons. They spoke at once.

"I thought the tsunami..."

“We are linked forever, the Spanish and Moroccans, we can't escape them." 
Nouari eyed Marc askance at this lament. "Who are you talking to?" he reminded him.

"Sorry," Marc mumbled, ducking his head. After they had secured latitude and longitude, he asked, "Are we going there?"

I don't know. He hadn't traveled for years. Now he would undertake a ferry crossing that he hadn't while immigrating. "I suppose we are. I am," Nouari corrected, "since you do not care for my kind."

"I said I'm sorry. Will you hold that over me forever?"

"For the next hour." Nouari rose.

"Will they notice we're gone?" Nouari stared down Rambla Nova, imagining flower stalls and street markets.

"They'll notice the food is gone."

Nouari wasn't listening, or Marc knew he would have shuddered to think of the men pursuing them. Marc adjusted the shoulder strap of his pack. "Why do you keep looking back?"

“My family's buried here." Nouari could feel their hands clutching him like tethers.

"Not in Morocco?" Marc raised his brow, raked back his hair.

"No." He had made his home here, though over the years, he had been reminded that he wasn't always considered a Spaniard. He recalled Marc's comment. "Perhaps you had better leave me here."

"Are you kidding? I can't leave the only electrical engineer I have."

Nouari thought he was being flippant until he met Marc's eyes and saw the fear.

"I don't want to do this alone," Marc said.

"You, fearsome leader of the jackals?" 
Marc rubbed his neck. "It's exhausting. I'm worn to the nub. I don't know how much more I have left." He left unspoken the consequence if he lost control of the chacals.

Nouari scanned the horizon. For some reason, Nouari didn't like to think of his demise. "Where's that car?"

Marc's brow cleared and his shoulders fell with relief. "I saw it by Sabroso."

"This place had the least tasty mussels," Nouari said as they neared the restaurant's glass front and white awning. Bless the shade. "Will the car need gas?"

"Probably. There," Marc pointed to a green Ford Fiesta next to a dead tree. "I call it The Booger Mobile. After the color."

"Thanks for the clarification," Nouari drawled. "Why didn't you take the car before?"

“Because it doesn't run, clown." Nouari and Marc froze as Hugo emerged from behind the Fiesta. He looked at Marc. "Right, botanist? You couldn't fix this alone."

Marc was silent. Perhaps he knew he had lost the upper hand over the chacals, or perhaps he could sense Nouari's feeling of betrayal. Marc hadn't mentioned any repairs.

"You didn't think we'd catch up to you by the time you started this tin can?" Hugo stalked towards Marc, eyes hard, and Nouari threw a staying hand in his direction.

"You can't stop us!"

"Oh, no?" Hugo twitched open a folding knife. Goddamn, weapons are what survived the apocalypse?

"Why would you keep us?" Nouari gestured.

Nouari's heart sank when Hugo knew the answer. "You're useful." 
Nouari glanced around for a weapon. Perhaps they should run and hope to lose Hugo and his comrades in the streets, though they could hear dust settle in the grave-quiet city. "We'll radio when we reach our destination," Nouari tried to cajole.

"What good will that do me?" Hugo's growl could rasp stone as he turned towards Nouari.

He was treading thin ground, but Nouari knew he must continue. "What can I do for you to let us go? Shall I find you another car?"

Hugo loomed over him for a moment. Then, abruptly, he began cleaning his nails with the knife. "You'll take me with you."

He was alone. Nouari's eyes bulged with surprise. The bandit's whiplash moods dizzied him, but Nouari recognized a haggle. "You'll get bored." "I don't think so," Hugo raised his immaculate knife as if to inspect it under the sunlight. Nouari recognized the warning. He looked at Marc. When that man offered nothing, Nouari set his jaw.

"Fine." He could feel Marc stiffen. Well, he should have said something. "But you will not kill anyone, and you will make yourself useful and not hinder us."

"Fine," Hugo scowled.

"And you will wipe your feet."

Hugo gave him a funny look, and clearing his throat, Marc dragged Nouari away before he could get them killed.

I should have given this more thought. Nouari's lips twisted as the ducttaped Fiesta rattled over the cracked road. Inside, the car had fallen silent as Marc, with one eye on the tide, followed the dry, navigable streets as he found them, sometimes narrowly escaping ocean surf. Nouari had underestimated the impact a looming Hugo, complete with 
knife, hunched over the rear transmission tunnel just behind the front seats, would have on conversation and Marc. Three hours later, Valencia's flooded, abandoned streets were depressing him, and the atmosphere in the car stifled him.

"At least the air conditioning works," Nouari offered, "Eh?"

Hugo, close enough to smell Nouari's breath, did not smile. "You said I had to make myself useful. How am I going to do that?" Nouari bit back something glib about muscle. "What skills do you have?" "I have none, I just have these." He held up his fist, scarred and swollen. Well, he wasn't a liar.

"Ahem. Yes." He was beginning to feel guilty. "You repaired the car. What about that?"

"It was just a loose wire to the starter." Nouari didn't need him to say that he had probably unhooked it himself before they arrived. "I'm not a mechanic, I only know enough to make trouble."

Nouari wouldn't dispute that. "Did you go to university?"

Hugo studied his feet. "No."

Nouari didn't respond, so Hugo insisted, "I had to feed my family."

"I've heard that before." It was probably even true. Many began life with a millstone behind them rather than a luxurious safety net. They hadn't all resorted to smuggling and murder, however.

“My parents didn't guide me."

"What would you have done if they had? Does anything interest you?" He wasn't sure when he had become the man's counselor.

Hugo must have felt overwhelmed. Scowling, he threw himself back in the seat with a violent swipe in Nouari's direction. "Tch, who cares? We can't read books when we need to survive." 
"Your friends had plenty of time to read books, if they wanted. Didn't they miss us, by the way?"

Hugo stared out the window, so Nouari glanced at Marc. "Let's stretch our legs."

They stopped next to a one-time florist's shop, Alejandro's Flowers in yellow script on the window. Hugo disembarked from the car without a word, and Nouari didn't blame him. He topped Nouari and Marc by a head; he must have felt cramped in the Fiesta. It gave Nouari an opportunity.

"Why have you suddenly lost your tongue?" he asked Marc as they leaned against the car.

Marc looked after Hugo as if wondering whether he could still follow him. "You're not our father, you know."

Nouari puffed up with affront. You try to help some people... "God forbid! I'm glad you've found your voice. Back there, he could have gutted us both, and you wouldn't have noticed." He crossed his arms.

Marc looked without seeing at the museum ahead of them. A breeze stirred the branches of a dead tree. Nouari had assumed Marc wouldn't answer when he said thinly, "I thought maybe it would be for the best if he did."

"What? To be shredded like carrots?" Nouari demanded, losing patience. If he wasn't Marc's father, Marc was nonetheless asking for coddling. "What are you talking about? Are you giving up?"

“Maybe it's all futile and never-ending. I've gotten my hopes up before. How do we know traveling south will avail us anything? How do we know north wouldn't be better?"

"France is flooded and God only knows what else. We don't know the terrain." Perhaps they had jackals too. "We'd have to go much further 
north than you imagine to reach safety." He knew Marc knew this. Marc was only suffering a paroxysm of doubt. Nouari would have sympathized much less if he hadn't experienced the same fear of disappointment only days before. How painful, hope, how dangerous.

"We know there are people south. A human answered our question." At least he hoped it wasn't a computer on a generator.

"If they were asking for help, we could be heading into worse."

“But it will be an adventure! I should have brought Hassan. He doesn't have this thinking problem."

Finally, at last, Marc laughed.

"Are you talking about me?" Hugo asked as his returning steps crunched gravel.

"Hassan," explained Nouari as they piled back inside the Fiesta.

Hugo turned to the window with brows flat in an expression that said he didn't believe them. Why did he ask, then? "You two are so moody, this is like traveling with my wife."

His throat closed as soon as he said the words, and his vision shrank to the dashboard in front of him. Marc and Hugo didn't notice as the car coughed back to life, and they began anew. Nouari looked out the window.

Bye, love.

"Are you sure this thing will carry us?"

The Tarifa sunrise painted La Hipoteca's bow gold. Dirty, scratched, and small in her truck trailer, she looked like salvation to Nouari. When they had towed her to the tide sloughing against the street a block distant, Nouari scrambled into the boat and gingerly patted the wheel free of dust with his palms. 
"What a difference, all this noise, next to the quiet interior, eh?"

"Do you know how to operate this thing?"

"Stop wringing your hands, Marc, and get in. Think of it like Venice."

Hugo followed Marc and, seeing Nouari goggling at the controls, pushed them both aside. He fumbled with the lines, and a breath later, the boat growled through the city and out to sea.

"I guess we discovered what he's good at," Nouari muttered to Marc behind his hand. They had found seats rather than tumble over the deck as the boat bumped over the waves. Thank God for drug runners.

"Were you two knuckleheads going to guess how to drive this?"

"It's good to see you laugh, Hugo, but I'm not a knucklehead."

Now Marc joined Hugo in laughing. Nouari grinned and enjoyed the sea spray.

It only took an hour to reach Tangier, and a silence fell as the corpse of the city emerged from the waves, the doors of the tiered houses become mouths to accept the sea, their walls browned and peeled by the tide. There were no seagulls.

"Where will we dock?" They should keep the boat.

"Whereever the sea drops us." Hugo's eyes searched the shoreline.

They wouldn't cooperate in distracting themselves from the gruesome sight. Nouari wanted to stave off the conclusion of their journey and possible disappointment just a little longer, but as soon as the water receded to knee depth, Hugo and Marc waded onto the street.

"Where was the signal from?" Hugo pivoted to laser-in on Marc. Damn, he was the Terminator or something.

Marc rummaged in his bag and, apparently having sacked a bookstore, retrieved a traveler's guide to Tangier. He had circled a point on the 
map inside. He pointed. "The coordinates suggest we should go that way."

Hugo nodded and started forward, shoulders swinging as he bit into some dried meat as if he were biting off the head of a fish. Where had he even got that from?

Nouari wasn't sure how they passed through the city while avoiding looking at anything, neither the deserted souks, the listing scooters, nor the discarded cell phones and toys. He wanted to gouge his eyes by the end, but eventually, they arrived at a tall historical house. The door was locked.

"Are you sure this is the location?"

"Yes..." Nouari said with waning confidence. He had got the coordinates right, hadn't he?

He didn't immediately notice the crackles. One moment he was watching a scarf flap in the wind, the next Marc exploded into movement, surging towards the alley.

“Wait!” Nouari and Hugo followed him past overturned bicycles and studded metal doors, under arching casements and up a set of stairs hewn from stone, all the time hearing that crackle crescendo, and now Nouari could hear a voice accompany the noise, he hoofed it faster, ignoring the complaints of his bad knee.

This door was not locked. They should have hesitated before they plunged into the flat, but that voice dragged them, panting, into a small, grease-stained kitchen, dimly lit. There, against the window, a radio sat next to a generator. Above the generator's whir, they heard a feminine voice.

"She's talking!" Marc nearly vibrated. They had graduated from Morse code. "What is she saying?" he asked Nouari, who stood transfixed. 
"She's saying that she'll return to the city for survivors at sunset, to please stay together and nearby. She has resources-"

"Wait, do you mean she's not in the city?"

"She's said she'll return, Marc."

"This could be a recording or a trap."

The man did know how to summon the bleakest possible outcome, didn't he? "Let's just wait until sundown and see. We have enough foodwhere's your pack?"

"I-“ Marc followed Nouari's stare at his shoulder and swung around. "Shit!"

"Go find it," Hugo growled, pushing Marc towards the door. Eventually, they were all combing the alley for the backpack.

"Looking for something?" A man in a scarred, brown leather jacket emerged from the shadows. One hand held a handgun, the other Marc's backpack. Marc recognized the blue "Traveler" logo on the strap.

"What do you want?" Marc asked.

He glared when Nouari said, "You can have the backpack."

"You are too kind," the thug said to Nouari. He glanced sidelong at Marc. "You should follow your friend's example."

"Get fucked by a fish, asshole!"

What the- Nouari oof-ed as Hugo thrust past his shoulder and into the armed stranger. The ear-piercing boom of a gunshot brought Nouari and Marc to their knees. They cringed in a corner of the alley, watching with round eyes while Hugo and the man rolled on the ground. Nouari wasn't sure whom he wanted to win.

"We should go," Marc's murmur shook. "Any stray bullet could hit us here." 
"What? Then get farther back. We can't abandon Hugo." Nouari supposed he had decided on the thug he knew. They swung back to the grim scene when another shot cracked out. The two brawlers, locked in a clinch, had slowed, Hugo wrestling down fewer and fewer punches from his rival and with less and less energy. Who had been shot? Nouari swallowed, unblinking and still as stone. Perhaps Marc was right, and he should seize this opportunity to flee, but something forced him to see this to its end.

Then Hugo raised the gun and struck the man in the jacket with the butt. Marc ducked at the thud and clutched Nouari's arm instinctively. Hugo rolled to one side, panting, and locked eyes with the other two huddled fixed as rabbits. After a moment, he gained his feet. "Let's go." Nouari wasn't sure if he should ogle the fallen man, but Marc, striding forward, had no qualms. "He's still alive."

Nouari jumped. "What?"

Hugo hadn't used his knife. Nouari hadn't expected mercy from him. It was a bad time to learn the bandit had a heart- or something. The saintly thug was already halfway down the alley, and Nouari scrambled after him.

The fight left a pall over the group. They walked in silence up the street. Finally, "We can't go too far. We'll miss the rendezvous."

Marc was wearing the backpack again. Nouari wondered what was so important that they had risked their lives for it.

“He probably wasn't alone." Hugo, curt. He didn't stop walking.

"When he wakes up, he'll be angry," Nouari added to that. He didn't like thinking that maybe it would have been better if Hugo hadn't held back. He didn't want to live in a dog-eat-dog world. 
"We can hide in one of the apartments looking onto hers. He can't search each one." For a man who had doubted the radio woman he argued passionately in her favor. There were only so many apartments the man would have to search, and it wouldn't take him long to sweep through a few rooms, but Nouari said nothing as Hugo agreed. If Hugo didn't mind encountering the man again, then who was he to complain? Nouari glanced at the gun in Hugo's waistband, next to the knife, and followed.

They settled in an apartment across from the one with the radio, a clean flat decorated with low mustard couches, yellowed lace tablecloths, and a worn red rug. Nouari sat on one of the couches. Hugo lay back on the other, closed his eyes and gave every indication of sleep. Marc went directly to the window. Would he wait there until Radio Woman arrived?

"We have hours until sunset," Nouari pointed out.

"That's what I'm worried about."

Nouari flung a hand. "You worry too much."

They idled there, Nouari humming old Egyptian songs and Marc thinking about the promise of people who weren't bandits, until the apartment grayed and the horizon darkened. Sunset, Nouari realized. They had made it! Perhaps we really do worry too much.

Marc clutched the casement, knuckles white, as the growl of a scooter rent the twilight. "It's her!" Then, staggering away from the window, "Shit!"

"What? What is it? Is she here to kill us after all?"

"It's not her! It's the guy from before!"

Nouari spared a few choice words for persistent thieves. Then he shook Hugo. "Hugo, Hugo! We need your brawn again!” 
Nouari's breath came faster as they heard their pursuer bull through apartments in the next building, doors crashing open and closed. The thief didn't care if they heard him.

"He's probably picked off people waiting for her before," Hugo said, dispassionate.

"What?" How did he arrive at that conclusion? Nouari sweated, imagining necklaces of human teeth in the thief's pocket. "What makes you think she's done this before or that anyone has heard her except for us?"

Hugo shrugged. “Maybe you're right.” He didn't notice Nouari's goggling as he hastened for the door. "Let's go."

"You need a new catchphrase, Terminator," Nouari muttered as they three fled down the stairs, but Marc paused at the next landing's open window. They heard an engine.

"Oh God, does he have friends?" Marc moaned. Nouari pushed him aside and looked at the road beneath them. A white Mercedes had stopped in the street. A figure with long, black hair climbed out and headed for the building sheltering the radio.

"It's her!"

Then the downstairs door opened and closed.

"Shit!" Marc and Nouaris said in unison and again when Hugo suddenly thrust his gun between them and fired down the stairs.

"Go!" Hugo shoved them, and for some reason they thundered down the stairs towards the thug. Nouari flinched as Hugo fired behind him, and he had time only to wonder when they would cross the thug's path before they stumbled upon him. He erupted like a panther from his corner as they passed, but Hugo was fast. He spun and fired and pushed Nouari and Marc onward. “Keep going!” 
They escaped into the square to find the woman running to Mercedes. She took in Hugo and his gun and jumped inside.

"Wait!"

Nouari ran in front of the car with palms aloft. In Arabic, he cried, "Wait!

Please! No weapons! See?"

Hugo helpfully tucked the gun away.

The woman studied them through the windshield, and Nouari could have sworn she considered running over them. Then she cracked open her window.

"What do you want?"

"We heard your message from Spain," Marc said in Spanish. She eyed him, and Nouari translated.

She glanced between them and hesitated on Hugo. He raised his chin.

"Okay," she finally said, gesturing them inside. They surged over the car so quickly, she probably reconsidered.

"Where do you live? Why did you send that message?" Marc began in a rush.

"First, let's get on the road," Nouari said, but when she had reluctantly started forward, the woman had her own questions. She asked for their names and origins. When she asked them how they survived, Marc and Hugo paused.

She noticed. She braked and turned her head, silver at the temples, to Marc and Hugo. Her brown eyes narrowed. "Well?"

She didn't have to say that she wouldn't move unless they confessed, they understood. Marc sighed. In accented English, he said, "We did what we had to."

She was quiet as Tangier passed them, and Nouari wondered if she had judged them unworthy. Then, "Do you have a community?" 
He shook his head. "There may be enclaves we haven't seen. Most people left."

"And your name?" Marc changed the subject with some haste. Likely he didn't want to discuss the Forum and his little band.

"Naima Barakat."

"Naima Barakat," he repeated, "professor of horticulture?"

Naima glanced at him in the rearview. "Yes?"

"I've read your work. Before the drought, I was a botanist." Marc was avid. Nouari supposed this was the botanist's version of celebrity.

"A botanist?" Her face tightened. "What was your concentration? Have you researched drought-resistant plant species? Are there more of you?"

Marc frowned.

"Why are you asking?" Nouari asked. They were outside the city now, and she pointed into the flat distance. "What..."

He fell silent as tents rose from the ground. "Are those..."

"A community," Naima smiled. "I've been collecting survivors. The city attracts predators, so we stay farther out. We're trying new methods now. We have a reverse osmosis machine, and we've begun planting saltbush and sugar beets using drip irrigation and strip cropping. We're harvesting gypsum plaster from the city to mulch the ground. There's no end of materials now. You're Spanish?"

Marc had been listening with mouth open. He nodded.

"Then I must show you-"

The sound of a motor intruded, and everyone but Naima swung around. "I'll give you three guesses," Nouari muttered.

“That bastard's back!" Marc yelled, staring through the rear window at the man on the bike. 
Naima's mouth set in a grim line. "I'll take care of it."

Nouari and Hugo peered at her.

Naima slapped the horn nine times in a strange pattern, and a motor bike emerged from the distance, veered near, and disappeared, but the driver had made a motion to Naima first. She nodded, and Nouari's heartbeat leapt as she accelerated towards the little makeshift town.

"Hey, aren't you..."

The bike behind them accelerated to keep pace. In the front seat, Nouari thought Naima intended to kill them all as the huts rushed at him. He cried out as she narrowly missed the village. Then, behind them, they heard a shout.

"Holy-!"

Nouari looked in the side view mirror to see the bandit rolling in front of his fallen bike and a spike strip. Cutthroat, Nouari admired.

"We raided the police station," Naima grinned like a shark.

"What will happen to him?” Nouari asked.

Naima shrugged. "We have prisons, we have schools. We have full civilization in our little haven."

Probably Marc could see the stars in Nouari's eyes. He laughed. "Prison is the marker of civilization?"

The car stopped, and Naima beckoned them out. A host of wide-eyed, multi-hued faces immediately crowded around them to pepper them with questions. Nouari answered whatever he could parse from the din, but Naima tapped Marc's shoulder and tugged him by his elbow, crooking her head.

Dying sunlight gleaned giants from their shadows and gilded the field before them. Naima gestured at the ground, where little green shoots 
waved at him in a gentle breeze. Marc smiled, immediately cheered by the determined little things, nature's perseverance.

"You know the rainfall's dwindled. We thought our soil irrecoverable too. But we've been testing drought- and salinity-resistant plants," Naima said.

"That's wonderful-"

Naima shook her head. "No. You're not seeing. This is an amaranth. You know in some countries, there was little time to test before disaster struck. We've had visitors and harvests from some of those countries, from many countries, in our little community. This one..." She tugged him again and pointed at a thick, spongy shoot among the rest, but that was not enough. Shaking her head and muttering, she pulled him down and curled his hand around the toothy little stalks. The scale-like leaves tickled his palms.

"Spain."

Marc's face slackened with shock, wonder.

Spain. Hope stabbed his heart again. This little succulent could save Spain. He could see her restored. "I have to find others, we have to-"

"You will," she said, "but for now, why don't I show you the rest of the nursery?"

It was the beginning. 


\section{Congruence Jehanzeb Dar}

Author Bio: Jehanzeb Dar is a Pakistani Muslim American writer, blogger, and independent filmmaker based outside of Philadelphia, Pennsylvania. In 2011, his chapter entitled "Holy Islamophobia, Batman! Demonization of Muslims and Arabs in Mainstream American Comic Books" was published in the textbook, Teaching Against Islamophobia. In 2014, his chapter about the objectification of women in comic books was published in The Bedford Book of Genres. He is currently in post-production of an independent film, Vilified, which he wrote, produced, and directed. Details about the film can be found on the official website: http://reverie-pictures.wixsite.com/vilifiedmovie

For a moment, Azal panicked.

She had been staring at the clock hanging in the corner of her office for God knows how long. Her eyes hurried back to her client, a middle-aged White man seated across from her in a comfortable armed sofa. Thankfully, he had not been making eye contact to notice her drifting away. He was leaning forward and had his hands buried in his dark brown hair, venting about personal issues that Azal had not been paying attention to. She shifted in her chair and sat up straight, discreetly taking a deep breath as if she had woken from a nap, and made an effort to track his story.

“... To change her mind, it's like, um, I know I shouldn't have done that, I shouldn't have gone over there," the man was saying, his voice shaking with remorse. Azal forgot his name and prayed that she 
had written it down. She glanced down at the notepad on her lap and saw his name written: William Extenkamper.

"I just don't know who I am anymore," he continued. "This was my dream job, to help do good in the world, to make it a better place, but I can't focus on anything, I can't concentrate at work. I just feel lost. I know that sounds cheesy, but that's what it is, you know? I'm not the man I was before; I don't know what to do. What do I tell Nina?"

Azal had no idea who Nina was. Obviously it was someone William brought up earlier in the session. Should I ask him to remind me? God, that would make him feel terrible, Azal thought.

"So, what I'm hearing is that this feeling of emptiness and guilt is having an impact on your everyday life," Azal paraphrased. Ugh, that sounded so mechanical.

William let out a sigh and stared vacantly off into space. "It really is," he said with a tone of realization, as if he had not framed his feelings that way before.

Suddenly, Azal felt a wave of heat come over her and she started to feel dizzy. The room seemed to slowly whirl like she was on a carousel. She pressed her eyes shut and tried massaging her temple. Within seconds, the feverish feeling faded away, but this time, William had noticed her discomfort.

"Hey, are you alright?" he asked. "I'm sorry; I've been rambling on."

"No, there's no need to apologize. I'm listening," Azal said, hoping that he would believe her more than she believed herself. "I just started to feel dizzy all of a sudden." 
Before she could say anything further, there was a knock at the door and she heard the office manager, Emma, call out to her. "Azal, your 3 o'clock appointment is here."

Azal looked at the time; it was almost 2:00. Wait a minute, I don't have a 3:00 appointment, she realized.

"Excuse me," Azal said to William as she walked to the door and opened it. To her surprise, no one was there. She saw the empty halls of the counseling center. All of the doors for the other counselor offices were shut. At the entrance of the building, she noticed Emma was seated behind the front desk, answering a phone call. It didn't look like she had moved at all. But how could she get back to her seat so fast? She just knocked my door, Azal wondered, mystified.

"Hey, did you hear me?" William asked.

"I'm sorry?" Azal replied, as she walked back to her seat and tried to regain her composure.

"I said, of course you're feeling dizzy, it's because you have to listen to crazy people like me every day," he said with a laugh.

Azal forced a smile, even though she hated the word "crazy" and how it stigmatized people with mental illnesses. Although she didn't hear most of what William said, she was confident that his problems stemmed from marital issues, not mental illness.

"Looks like my time is up," William said while looking at his watch. "I wish we had more time to speak."

Azal felt terrible. "I apologize, Mr. Extenkamper, it's really unprofessional of me to zone out like that. I think I have you scheduled for next week, don't I?"

“No, I mean, I wish we could talk outside of all this," William said while pointing to Azal's office. 
"Oh," she responded. "Well, I'm flattered to hear that, but as you know, ethical standards of my profession prohibit-"

"I know, I know, no boundary crossing, ethics code, blah blah blah. I understand," William said as he stood up and walked towards the exit. "And please, call me William."

Azal smiled, "Ok. Have a good day, William."

Instead of taking her lunch break at the counseling center, Azal went out for a drive. She recalled how her psychology professor used to tell the class to never drive when you're stressed. Azal could think of many reasons why driving wasn't a healthy way to calm one's senses, but it worked for her. But she was still troubled by the way she lost focus with her client. It wasn't like she just stopped paying attention. She did not recall greeting William or anything earlier in their session.

Back in her office, Azal finished eating her sandwich and closed her eyes for a few minutes. She needed to stop thinking about the previous session. She had received her counseling license less than a year ago and was often worried about losing her job.

Suddenly, there was a knock at the door and she heard the voice of the office manager, Emma. "Azal, your 3 o'clock appointment is here."

Azal opened her eyes and promptly opened the door. This time, she saw Emma, an older White woman standing in the doorway.

"Emma," Azal said, though she was unsure if she was relieved to see her or further confused. "Were you here earlier?"

"Well, of course, I've been here since 7 in the morning," Emma answered with a cheerful smile.

"No, I mean, did you knock on my door about an hour ago?" 
“I don't think I did, no. Not since Mr. Extenkamper arrived. Why?"

"It's weird, I could have sworn..." Azal started to say, but then shook her head. “It's nothing, never mind. I thought I didn't have a 3 o'clock appointment?"

“Oh, you didn't, but this a new client. She put in an urgent request for you, so I put her on your schedule."

"She won't mind," a young voice said. Walking past Emma and into Azal's office was a South Asian teenager. She was wearing a dark green jacket, a black top, and blue jeans. Her sneakers were terribly worn and stained with dried mud.

Emma looked at Azal and smiled, "You know I hate scheduling last minute, but you're the only therapist today with an open slot for 3 pm. She really looked like she needed someone to talk to. I hope you don't mind."

In Yardley, Pennsylvania, there weren't many people of color, let alone South Asians. Azal was not oblivious to the countless stories of people of color being misunderstood, misdiagnosed, and mistreated by White counselors. Azal was not sure whether the teenager was Pakistani, Indian, Bangladeshi, or of another background, but she wouldn't have been surprised if the young woman actively sought out a non-White counselor.

"No," Azal said, "Not all." She thanked Emma and walked back into her office to greet the teenager.

"My name is Quratulain," she said before Azal could introduce herself. "I'm 19 years-old, and yes, I agree to all the terms in the informed consent." 
Azal was not only caught off guard by Quratulain's spontaneity, but also by the way the 19 year-old navigated through her office. Quratulain opened Azal's drawer and knew exactly where to find the informed consent form.

"I understand that my confidentiality privileges end if I disclose serious intentions to kill myself or others," she said while signing the document.

Azal smiled and watched Quratulain flop onto the sofa. "Well, you seem to know about your rights in therapy."

"Yeah, well..." Quratulain replied with a shrug. She abruptly got out of the sofa and walked to one of the corners in the office. She reached behind the bookshelf and pulled out a plastic water bottle from the case that Azal had stored there.

"How did you...?" Azal began to ask in bewilderment.

"Can we just skip past all of the boring stuff?" Quratulain asked, returning to the sofa. What 'brings me in today' - that's going to be your first question, right?"

Azal was still trying to keep up with Quratulain's pace. "Well, um, yeah, it actually is."

Quratulain let out a sigh and took a big sip from her water bottle. Azal leaned against her desk and observed the exhaustion in the teenager's eyes. It looked as if she had been deprived of sleep for days. Her black hair rested on her shoulders and her skin was brown like Azal's, but slightly darker. After she finished her sip, she sat quiet for nearly a minute.

"So, what is that brings you in today, Quratulain?" Azal asked in her warm counseling voice. 
Quratulain sighed again. She looked scared, but also irritated. "I'm trapped," she said finally.

"Trapped?" Azal asked. "How do you mean?"

"I'm trapped in a time loop."

"Ok," Azal said, nodding. "How so? Experiencing the same pattern of events in your life?"

"No, I mean I'm stuck in a time loop," she answered, annoyed. "I try leaving, but I keep getting transported back to this exact moment in time."

Quratulain's response took Azal some time to process. She must mean this figuratively, she thought.

"Um, could you elaborate-"

"I'm not from here. Not from this time, I mean. I'm from the future." Quratulain said. Her voice carried a tone of desperation, one that was desperate to be believed.

Azal felt her heart sink. She immediately felt sorry for Quratulain. Such a young age for someone to suffer from mental illness. It especially bothered her when she saw young girls of color suffering due to lack of access and proper treatment from the mental health field in general.

“Look, I know you don't believe me and you think I'm delusional, but I'm not," Quratulain said sternly. "I traveled back in time because I needed to escape and now I'm stuck here."

Azal nodded again, "Ok." She remembered her training about person-centered therapy and showing unconditional positive regard to clients; about working within the inner world of the client to avoid harming them or dismissing their reality. She recalled case studies where highly religious clients claimed to be possessed by spirits, and 
how culturally sensitive clinicians chose to "dialogue" with the spirits instead of pathologizing their clients. Maybe I should apply the same logic here, Azal contemplated.

"So, you traveled back in time to escape. Escape from what?" Azal asked, careful to keep her tone neutral.

"Here we go again," Quratulain said. Azal wasn't sure what Quratulain meant, but let her to continue. "In the future, I was detained by the U.S. government in one of their secret prisons. This one must have been somewhere in Afghanistan, Pakistan, or India because I was in Pakistan at the time I was captured."

“That's terrible. Why were you detained?" she asked.

"My grandmother worked with survivors of drone attacks in Waziristan because, you know, nobody gives a shit about them. Years later, my parents followed in her footsteps after the U.S. began using Enhanced Drones throughout the rest of the region. People were meant to believe that self-aware machines were more ethical because they could differentiate between civilians and combatants. But that was all bullshit. Combatants, non-combatants, it didn't matter - people still died. And Muslim blood is cheap; no one cares if it's one dead Muslim versus a thousand of us."

"Aside from the advanced technology you described, it doesn't sound too different than today," Azal said. She also made note of Quratulain's imagination. Possibly augmented by the trauma, she thought.

"It's only different in that things get worse," Quratulain said while taking off her jacket. "I spent the last six years living in Pakistan with my parents and grandmother. They were trying to collect testimonies of the survivors and help them press charges against both 
the U.S. government and the Pakistani government for their complicity in authorizing these weapons. And then one night, our house in Lahore was raided by soldiers who were part of a covert military group. They called themselves Guardians. They functioned like machines and were extremely precise in everything they did. Rumors exist about them being prototypes for some cyborg soldier project that the government was testing. But I didn't need proof to know that they were inhuman."

Quratulain paused for a moment. This seemed to be difficult for her to share.

"We were blind-folded, drugged, and thrown into separate cells. My grandmother was in the cell next to me. She had trouble breathing and I cried out to one of the Guardians, but those stone-faced bastards didn't do anything. I pulled at the prison bars until I could feel the bones in my arms cracking, until I could feel the bars digging into my palms. There was nothing I could do. She died right in front of me."

"I am so sorry," Azal said, horrified at Quratulain's experiences. “That's terrifying, I can't even begin to imagine...It sounds like you and your grandmother were really close," Azal made an attempt to focus on anything positive.

"She taught me everything: Islam, how to speak Urdu, how to keep strong, how to hold my head up high, no matter what the odds were," Quratulain said. "When my parents were caught up in their work, my grandmother was there. I just don't know how to get home without her."

"You've made it this far," Azal said encouragingly. "All of the strength it took you to get here - it's a testament to you, as much as it is to her. I'm sure she would have been proud of you. Not to mention, you managed to escape, obviously. How were you able to do that?" 
Quratulain's answer came slowly: “I... I summoned a portal in my cell."

"A portal?"

"It's a wormhole. It connects two distant points in space and time. I can generate one and pass through it, but I don't have control over where it takes me."

"And when you traveled through... the wormhole, you ended up here?" Azal asked. Quratulain nodded.

"How are you able to summon it?" Azal followed up.

"It's activated through a stone. It's called a turbah, it's what many Shia Muslims use in their prayers. But this one is different."

"Oh ok, I'm not familiar with that," Azal said. Having been raised Sunni, she didn't know too much about Shia beliefs and practices.

"It's a small clay stone that worshippers touch their foreheads upon when making sajdah, or prostrating in prayer. It's believed to be a practice of the Prophet."

“Oh, I didn't know that before," Azal said. "And is there something unique or special about this particular turbah?"

"My grandmother gave it to me," Quratulain replied. "She said Hazrat Fatima gave it to her in a dream...."

"And what does this wormhole look like?" Azal asked.

"Beautiful," Quratulain answered simply. "But frightening at the same time. It's like when you look at a solar eclipse: you're astonished by its beauty, but also scared because it reminds you how small we are in the universe."

Azal nodded as she thought about her next question.

"It's exhausting having to explain this over and over again," Quratulain said while pressing her hand against her forehand. 
"I'm sorry," Azal said. "That must be draining. How many people have you told this to?"

Quratulain lifted her head and locked her gaze on Azal. The troubled look in her eyes unsettled Azal unexpectedly.

"Just you," Quratulain said.

"Ok, so you didn't tell any friends or-"

"This is the thirteenth time I've met you." Quratulain interrupted. "The thirteenth time I'm having this same exact conversation with you in your office. The thirteenth time I'm telling you my story. It's an endless loop."

Azal felt a shiver run down her back. For a second, she felt terrified - terrified that Quratulain might be telling the truth. She thought back to the knock at her door and the way Quratulain knew her way around the office. It was as if she had been here before.

Nonsense. That's impossible. Azal tried to force herself to block out the irrational thoughts.

“It wasn't déjà vu you experienced earlier," Quratulain said. "It was your mind seeing the future because I had already been here. Then the day got reset and I repeated it with you."

Azal felt stunned.

“Time doesn't travel in a straight line," Quratulain explained. "It curves, like a giant circle. Thanks to this loop I'm stuck in, the people I come in contact with also get affected in some way or another. In this case, since I've been interacting with you, your mind temporarily went in circles and you saw bits of the future."

Azal's mind was bombarded by a flood of conflicting thoughts, but she also noticed her own curiosity growing - a curiosity that disturbed her because it implied some part of her believed Quratulain. 
“So, you're saying that we've spoken before, on this same day, Thursday, October 6th, 2016," Azal said.

"Yes, and I stay in this time until tomorrow because, for whatever reason, the wormhole doesn't generate until then. But when I walk through it, it doesn't take me home. It brings me back to today, right outside this counseling center at around $3 \mathrm{pm}$. Everything resets and no one remembers me, as if I had never been here before. Yet I remember everything.

"And... when you and I speak, what happens in those conversations?"

"I ask you a lot of questions, about who you are and your life in general. You're resistant at first and tell me that this session is supposed to be about me. But you finally open up."

"And what do I say?" Azal asked hesitantly.

Quratulain ducked her eyes and responded, "I know that you're 32 years-old, you just received your counseling license... and that you're afraid of failure. You worry about losing your job, but more than anything, you're afraid of letting people down, especially those close to you."

Azal felt like her mind was being read. No, this could apply to anyone, she thought.

"You hate living in this town. You hate always being the only Muslim and person of color wherever you study and work. At the same time, you fear that this place is part of you and that you can't really let go. You have a boyfriend, but you don't like calling him that because you're not sure where the relationship is going."

Azal stepped away from her desk and turned her head to hide her alarmed state. "Ok, just stop...” 
Quratulain continued. "You're ashamed you can't speak Urdu and feel out of touch with your community. You want to reconnect with your roots, but you don't know how-"

"How do you-?"

"You wish you could believe in God because you often feel alone and death frightens you-"

“Ok, that's enough!” Azal shouted. "Let's um..." She tried to retain her professional counselor voice, but she was shaken by the details Quratulain knew about her.

“Don't worry, I'm not here to preach to you," Quratulain said.

"How do you know so much about me? I've never shared those thoughts with anyone."

"I told you," Quratulain said. "I've been here before."

Azal was still recovering from how startled she felt. Quratulain stood up and threw her jacket on.

"I have to go now."

“Where are you going?” Azal asked.

“There's something I have to do. If it doesn't work, then I'll be here in the morning."

"I'm actually not in the office tomorrow," Azal said. "Fridays are my day off."

Quratulain stopped at the doorway and faced Azal before exiting.

"Trust me. You'll want to see me tomorrow."

“She’s obviously delusional," Khurram said. 
Azal was slightly slouched on a beige leather couch in Khurram's fancy apartment and listened to him express his blunt opinions about Quratulain. She knew she wasn't supposed to share details about client sessions with unauthorized individuals due to confidentiality agreements, but Azal made an exception for Quratulain's case. She also trusted Khurram, whom she had been dating for over a year. He was a professor of Islamic Studies at a prestigious university about an hour away from Azal.

"You can't jump to that conclusion," Azal said with a note of defensiveness in her voice. She watched him in the kitchen as he opened the refrigerator. The quiet night sky was visible from the window beside him.

"Like, it doesn't make sense," he said. "If she's from the future, then why come to you? Wouldn't she try to find some astrophysicist or some Doc Brown-type guy to help her?"

"What, you don't think I'm well versed on the science of time travel?" Azal said playfully.

Khurram smiled as he poured himself a glass of juice. Her gaze remained on his smile, a sight that she loved seeing, especially after the distress she experienced in her counseling sessions. He wore thickframed glasses that matched handsomely with his brown skin and neatly trimmed beard. His blue checkered dress shirt had been unbuttoned and was worn over a plain white t-shirt.

“Hmm, well for all I know, with all the information you can't tell me about your clients, maybe you are," Khurram said, returning the playful tone.

"Yep, it's one of my secret talents," Azal said. 
"Oh yeah? What other hidden talents do you have that I don't know about?"

"If you stop wasting your time in the kitchen and come over here, maybe I'll tell you," she said.

"Yes, ma'am," Khurram replied, quickly making his way to the couch. Azal wrapped her arms around his stomach and rested her head against his chest. She let out a sigh and tried to shut off her mind. She just wanted to rest and forget everything she experienced earlier in the day.

"Thanks for asking me if I wanted something to drink, by the way," Azal said, continuing to tease Khurram.

"Ah, I'm so sorry. It's cranberry juice, you want some?" Khurram said

"Yes, please."

“Sorry, I wasn't thinking," Khurram said while walking back to the kitchen.

"Yeah, not with your brain anyway," Azal said with a laugh.

"Ha ha, L-O-L," Khurram replied sarcastically. Azal sighed and looked out the window, at the seemingly empty night.

"You know, it was like she read my mind. I had this weird déjà vu before the session started, but it felt so real. It was like a vision, I've never experienced anything like that before."

"It's just your mind playing tricks on you," Khurram said from the kitchen.

"But she knew exactly what I saw in my mind. How could she have known that?"

"A lucky guess maybe?" 
Azal shook her head. It was too accurate to be a guess. Her eyes were still looking out the window.

"In graduate school, my theory of choice was person-centered therapy," she said. "It states that one of the most important and basic principles for counseling is congruence - that counselors should be their authentic selves, not assume 'expert' roles or carry a façade of professionalism. The goal is that it is genuinely you in the session, connecting with someone on the most basic human level."

Khurram walked back to the couch and handed Azal her drink. He sat a few spaces away from her and listened.

"Throughout my work, I try to be real with my clients, so that they experience me as I really am," she continued. "Not as someone who is going to dictate what she feels is 'best' for them. But today, with Quratulain, I realized that my real self surfaced for the first time in a session. I didn't have the answers. All of the confusion and uncertainty I had, all of my concern for her, and even the anger I directed at her things that clients are not supposed to see - she saw all of it."

After speaking, Azal took pause. A question crept into her mind, one that she didn't feel comfortable sharing with Khurram, even though she wanted to. The things Quratulain shared with me, the impossible things, Azal thought. Are you still congruent when you start to believe the impossible? Azal quickly pushed the question out of her head.

"Yeah, but Azal, I'm sure that approach has its limitations," Khurram said. "I understand not wanting to take a more directive role as a counselor, but some people need direction. Some people need real medical treatment and you need to ask yourself: are you withholding Quratulain from that?" 
Azal knew that there was some truth to Khurram's words. He continued, “I know you don't like diagnosing people, but why don't you refer her out to someone else? Let her be someone else's headache. Maybe send her to one of the psychiatrists at the agency."

Azal sat up straighter on the couch and faced Khurram. "Are you kidding? Do you know what they'll do to her? They'll institutionalize her-"

"No, they won't," Khurram said, trying to be reassuring.

"She's a Pakistani Muslim girl who escaped violence perpetrated by the U.S. government. They already think something is wrong with her before she opens her mouth. If she was attacked by the Taliban, we'd see politicians and women's rights organizations lining up to support her with all the medical and mental health services she needs, but she was the 'wrong' type of victim. She survived a raid from American soldiers."

Khurram chuckled, "Didn't she say robot soldiers?"

Azal was appalled at Khurram's reaction. "Khurram, she was severely traumatized. Not to mention, she watched her grandmother die in front of her. Her mind is just trying to make sense of what happened to her and her family."

"But do you really believe her?" he asked.

Azal paused. Again her mind wrestled with questions.

"I don't believe she traveled from the future," Azal said. "But I definitely believe she survived an attack."

"Yeah, but then she said she was taken to a secret prison. These places are insanely guarded. How could she have escaped? Think about that for a second, when was the last time you heard of someone escaping Guantanamo Bay?" 
Azal went quiet.

"Besides Harold and Kumar," Khurram said and laughed. Azal didn't find it funny.

"So, what are you saying?" Azal asked.

"I think she made it up," Khurram said, pleading his case. "She sounds like one of those radical anti-American leftists who just wants attention."

"What?" Azal was infuriated. "The U.S military attacks her and you're going to label her 'anti-American'?"

“Come on, you've never heard of people with persecution fantasies? How can you rule that out when she's talking about AI robots and time travel?" Khurram said defensively.

"I told you, she's traumatized-"

"Or, she's making up the story to get famous on the internet."

Azal scoffed. "I can't believe what you're saying. She's a teenager, she's a victim of-"

"Yes, exactly! She's a teenager. And you know how teenage girls can be."

The conversation came to a halt as Azal looked at Khurram with disdain. She grabbed her jacket and started to walk towards the door.

“Azal, wait!" Khurram rushed to follow her. "I didn't mean it like that. I'm not singling girls out; teenage boys can make up stories, too."

"I need to go," Azal said as calmly as she possibly could.

“No, please don't. You're an hour away, come on, why are you being like this?"

“Because you're being an asshole," Azal said. 
"I'm sorry, I know," Khurram said while gently holding Azal's hands. "Everything was going so well tonight. Let's just sit down and watch a movie."

Azal missed the feeling of his hands locking into hers, but she didn't want it. Not tonight.

"Khurram, no..." She said while pulling her hands away from him. She gently, but firmly pushed him away.

"I was just worried about you," he said. "You worked so hard to get your license and I don't want to see you jeopardize losing it."

Azal wanted to push Khurram harder, irritated by his condescending concern. She felt her teeth grinding. "No, I don't need you worrying about me like that," she said sternly.

"I'm just looking out for you-"

"Can you just stop saying-" Azal cut herself off before she got angrier than she wanted to be. "Ok, look, I need to go. I just... I need to be alone right now." She turned around and exited the apartment. Khurram didn't follow.

$* * *$

The next morning, Azal shot straight up in bed and screamed. She had a nightmare, but could not remember what it was. She looked at the clock on her side table. It was a little past $6 \mathrm{AM}$. She sighed and fell back on her pillow, frustrated. She was relieved that she was off today.

A few hours later, she woke up and walked to the kitchen. She noticed there were over 20 missed calls from Khurram. She turned on the TV and, to her horror, she realized that something terrible had happened: the local news was reporting about an attack on a mosque. 
Azal had been familiar with the mosque, but it was over an hour away and she didn't frequently attend it. The victims included men, women, and children. The perpetrator was identified as a 43 year-old White male: William Extenkamper.

"No," Azal struggled to say. She felt suffocated by the sorrow and rage that swelled inside her. This is my fault. How could I have not seen the signs? She knew there was only one person with answers.

"You knew this was going to happen!" Azal shouted at Quratulain in the counseling office. Azal's rage and grief cried out of her. Quratulain sat quietly, disturbed by the events.

"You must have known him," Azal said, trying to make sense of it all. "That's why you told me that I would want to see you today."

Quratulain shouted back, "What, you think I planned this? Why would I attack a mosque!?"

Azal took a moment to calm herself.

"You still don't believe me, do you?" Quratulain said.

“It doesn't make sense! You can't be from the future. It's impossible! If you're from the future, then why didn't you do anything to stop this? If you knew if it was going to happen, couldn't you have saved those people?"

"You don't understand," Quratulain responded. "Every day, I try to prevent it from happening, but there's always something that stops me."

"What do you mean? What are you talking about?" 
"This attack is well known in the future by the Muslim community. When I first came here and recognized the date, I tried telling you about it, but you reported it to the police. You weren't sure if you believed me, but you also didn't want to jeopardize losing your job knowing that there would be a potential attack. The cops took Extenkamper into custody, but they released him after concluding that he wasn't a threat. I tried to stop him myself, but I couldn't reach him in time. The murders still happened."

"After that, I activated the wormhole, but like I said, instead of taking me home, it brought me back to your office a day before the attack," Quratulain said.

“Why didn't you just drug him and lock him somewhere?" Azal asked.

"I tried that on my second cycle here. But somehow, the drug doesn't work properly and someone always finds him - either a cop or someone in the neighborhood. I tried killing him too, but it's like, I don't know, some supernatural force protects him."

"Where did you go last night?"

Quratulain looked at Azal, "I wired a bomb to his car. I waited until he got in, but it never went off."

Azal shook her head in disbelief. "Why would he do this?"

"Before the attack, he was outed as being an FBI informant," Quratulain said. "He infiltrated the Muslim community here, pretended to be a convert, and eventually married a Muslim woman. He spent years in the community, creating profiles of everyone in the mosque and reported it back to his superiors. One day, his wife Hadiya grew suspicious of him randomly walking out of the house on certain nights. She followed him to a bar where he was meeting with some other 
agents. She confronted him there and she found out everything. It devastated her, that everything was a lie and that the person she loved saw her as a target, a mission. She left him and moved out with their daughter Nina. They planned on leaving the country after today, but..."

Azal felt a weight of guilt on her. If only she had been listening to him.

"It's not your fault," Quratulain said to her. "I know you feel responsible, but there was nothing you could have done. He never gave you any clues about what he was going to do. It's like... the past cannot be changed. But I refuse to believe that."

"Maybe it can't be though. Maybe this is how it's meant to be," Azal said hopelessly.

“No, I can't believe that," Quratulain said. "Remember how I told you that the wormhole doesn't open until today? Well, it only opens after the attack has happened. It's like I'm being told that I can change it, that I just need to try again."

“But I don't understand. Why waste your time telling me everything yesterday? You could have used that time to find other ways to stop him," Azal asked.

"Because I decided to try something different this time and find someone else to go through the wormhole," Quratulain said, looking directly at Azal. "And in order for that to happen, I needed someone who believed me. Someone who would listen to me without judgment and would make every effort to understand, even if it meant considering the impossible."

Azal began putting the pieces in her head. On Quratulain's thirteenth cycle in the past, she planned on using a bomb to kill 
Extenkamper. Since that didn't work, she relied on her backup plan: to convince Azal to travel into the past.

Quratulain said, "Maybe you're the one who's supposed to go through the wormhole. Maybe you're the one who can stop it, not me."

Azal's response came impulsively.

"I'll do it."

In order to activate the wormhole, Azal needed to face Mecca and pray. Quratulain and Azal had cleared space in the office to make room for prayer. Quratulain had placed the turbah at the top of a prayer rug - it glistened like a gem. Azal also noted the inscription on the turbah, reading "Ya Fatima" in Arabic. It had been a long time since Azal prayed, but she was amazed at how the verses came back to her so fluently. After the prayer finished, the turbah glowed like a lantern, shining a beam of light against the wall. An ethereal, round shaped 'window' with misty edges emerged. Inside the window was what appeared to be an endless field - filled with brown barley gently blowing with the wind. The mystical landscape was softly lit by a blue-violet evening sky. Quratulain was right, she thought. It is beautiful.

"I don't know what will happen when you pass through. You could get lost in time, for all I know," Quratulain said.

"Well that's comforting," Azal said.

"But hopefully you'll be in that field. Now, this is really important: once you're there, you need to keep running. Don't get distracted by what happens around you and don't change direction; just keep going forward until you're taken back in time. You should end up at your office, yesterday. Insha'Allah." 
"Insha'Allah," Azal repeated.

Quratulain smiled briefly and then hugged Azal. Azal was caught off guard, but she embraced her back. The last time Azal had hugged someone so close was when she moved away from home.

"I'll be alright, ok?"

Azal walked closer to the shining portal.

"Come back for me," Quratulain said to her. "Come back for all of us."

Azal nodded, took a deep breath, and stepped into the light.

In an instant, she was in the field. She was startled by how quickly it happened. She looked around and saw nothing but endless fields of barley. Damn, which way is forward? The long grass started to shake and she heard a low, menacing growl. It sounded like an animal, but an animal unlike Azal had heard before. The ruffling of the grass crept closer, reminding her to run.

Azal charged forward, away from the noise. She heard more sounds of creatures around her. Her feet raced through the barley and then heard sounds of human voices whispering, talking, shouting, screaming. There were too many of them to hear anything coherent. She continued to run, her feet pounding on the dry soil below. She heard swords clashing, horses neighing, gunfire, distant explosions, cars driving by, planes taking off - the sounds of different time periods throughout history. Azal couldn't help but scan her surroundings to find the origin of the sounds, but she saw nothing except the swaying barley. She looked to the sky and saw a flock of birds soaring. As the birds flew closer to the earth, her eyes widened when she realized what they really were: a swarm of arrows raining in her direction! She frantically ran 
diagonally, towards open space. The arrows stabbed into the ground one by one, the last of which nearly piercing through her foot.

Would have been nice if you prepared me for that, Quratulain, Azal thought. She continued to run, but was worried that her direction changed. She noticed that the sounds were slowly fading. Everything became eerily silent. Suddenly, her foot fell through air and she stumbled forward. The earth beneath her had vanished.

The ground was gone. The field was gone.

She spiraled into a vacuum of nothingness, her cries silenced by the void and her hands reaching for anything to grab a hold of.

She continued to fall into mystery.

A radiant sun forced Azal's eyes open. She lay on her back and slowly sat up. She noticed bits of sand scattered on her shirt and pants. She observed her surroundings and found herself lying on a flat desert plain. A few feet away from her was a lake of clear water, glistening in the sunlight. She climbed to her feet while turning to view the vacant landscape around her. Am I dead? Is this the past?

When she turned around to look at the lake again, she was startled by a green-clothed figure sitting on a horse. The horse was so luminous that it took a moment for Azal to see that it had wings! She remembered stories her mother used to tell her, about a majestic horse with wings that flew the Prophet to the seven heavens. Could this be...?

The person wearing the green hooded robes was difficult to see, but then Azal saw the person gesture to her, inviting her closer. Azal was hesitant at first, but she walked towards the lake. She saw that the person in green was a woman with dark skin and black hair. She smiled 
at Azal and climbed off the horse. The woman held her hand out to Azal, asking her to follow her closer to the lake. "Who are you?" Azal asked.

"A Friend of God." The woman replied in Arabic, but somehow, in this place, Azal understood her. Azal touched the woman's hand and felt a wave of warmth fill through her arm. She followed the woman and watched her kneel by the lake. The woman touched the pool of water and, unexplainably, the entire lake rippled softly. Soon, a vision appeared.

In the lake, Azal saw an image of an older woman. She must have been at least 70 years-old. She was seated against a wall and looked to be in immense pain. She looked familiar to Azal.

"Wait, that's me," Azal said, turning to the woman in green. The woman nodded and looked back into the water. Azal couldn't believe she was seeing her future self. Then she heard someone screaming - a familiar voice. It was Quratulain!

The vision revealed that the older woman was in a prison cell, gasping for air. Quratulain was calling out to her and shouting at the guards to help.

The woman in green spoke to Azal: "She is your granddaughter." The realization overwhelmed her. She continued to watch and listen.

“Open the gate! Can't you see!? She can't breathe!” Quratulain was shouting.

The older Azal of the future called out to Quratulain, "Quratulain, listen to me! Forget them, listen to my voice! You know how to escape. Remember how I showed you."

"But we tried it before, Nani jaan. It doesn't work-"

"It will work this time, trust me," Azal's older self replied, struggling to breathe. "Come back for me. Come back for all of us." 
Before the vision in the lake faded, it showed Quratulain using the turbah to activate the portal. Azal turned to face the woman in green.

"She knew I was her grandmother, didn't she?"

"Yes," the woman in green said. "That is why she came to you."

"She has been through so much," Azal said. "Not just her. So many people have suffered."

"People like you can change that," the woman said. "If you believe you can."

"But Quratulain tried to change things - numerous times. Nothing happened."

"Because you needed to come here first," the woman said, placing something in Azal's palm. "Nothing happens except that which Allah has ordained for us."

Azal opened her hand and saw the turbah that they used to travel through time.

"You know whom to give this to," the woman in green said, before turning away and walking back to the horse.

A bright light emanated from the horse's expanded wings and shone into Azal's eyes.

"Wait!" she cried out.

She had so many questions. But it was too late, the light engulfed her.

Azal eyes shot open in her bedroom. She was sitting up in bed and saw the morning light come through the window. I'm back, she thought. She looked at the clock on the side table reading 6:00 AM. It must be Friday again. Azal threw off the blanket, grabbed her car keys and rushed outside the house. 
She quickly started her car, slammed the gear into reverse and sped out of the driveway. Cars were lining up at a traffic light ahead, but Azal turned onto the shoulder lane, desperately racing past traffic. On the next road, she pressed down on the accelerator, switched lanes, and drove onto an exit ramp. She tried her hardest to remember the directions to the mosque. Her foot felt locked on the pedal, speeding past cars in the lanes next to her. $70 \mathrm{mph} . . .75 \mathrm{mph} . .80 \mathrm{mph} .$. She had never driven so fast in her life.

When she finally reached the mosque, Azal sped into the parking lot. It was too early for Friday prayers, but classes were about to start at the Islamic school attached to the mosque. She rushed through the prayer spaces and hallways, searching for any sign of Extenkamper or Hadiya. Suddenly, one of the doors near the parking lot burst open and Azal saw Hadiya trying to exit the building. Extenkamper followed with a gun raised and pointed. "Don't make me shoot you!"

Azal stood in front of Hadiya. "Stop! William, what are you doing?"

"Azal?" Extenkamper said, confused. He started to lower the gun.

"Just put the gun down," Azal said, calmly. "You don't want to do this."

"How do you know what I want? You can't even help me get back with my wife!" he shouted while sobbing at the same time.

Hadiya shouted, "You're a liar! Your whole life is a lie." Behind Extenkamper, at the opposite end of the hall, Azal saw a few Muslim teenagers cautiously walking closer to apprehend Extenkamper. 
Azal wanted to motion them to get back inside their classroom, but she didn't want Extenkamper to notice.

"Listen, I know things have been difficult for you-" Azal started to say.

"I said I was sorry!" Extenkamper interrupted. "Isn't that enough? It was wrong of me to spy on everyone here. But I'm a different man now."

“And maybe you are, but that doesn't mean she's obligated to be with you. That's up to her," Azal said.

"Well, she doesn't know any better! She's my wife!"

Hadiya stepped in again, "You threaten to kill me and then expect that I come back to you? I'll never be your wife."

"Move aside or I'll shoot you both." Extenkamper said to Azal. "You can't change what's going to happen."

"You're wrong about that," Azal responded. She discreetly pressed the panic button on her car keys and heard the alarm go off. Extenkamper was started by the sound and turned his head briefly. It was enough for the distraction she needed.

She charged forward and drove her shoulder into Extenkamper's midsection, knocking him hard onto the marble floor. Hadiya rushed to help Azal and tore the gun out of Extenkamper's hand. He tried to get back to his feet, but Hadiya swung the weapon and smashed it against the side of Extenkamper's head. He fell to the floor, unconscious. The children standing by the classroom door cheered.

Azal scanned the halls of the mosque, making sure everyone was clear of danger. She worried that something would still go wrong, but nothing did. Everyone was safe. The past had changed.

"Alhamdullilah," Azal said. 
After Extenkamper was taken into custody and the mosque was secured, Azal returned to her office. She saw Emma sitting at the front desk.

"Azal, thank God!" she said. "I heard what happened, I was so worried about you-"

"I'm fine, Emma. Listen, did you hear from Quratulain?"

"I'm sorry, Qur...who?" Emma asked, confused.

“My 3 o'clock from yesterday. Pakistani girl, long black hair, a little shorter than me?"

"But you had no 3 o'clock appointment yesterday," Emma said. Azal nodded.

"Of course not," she said out loud. She hasn't been born yet. As Azal made her way home, she thought about the frightening future Quratulain described. If stopping the attack on the mosque was possible, then maybe there were ways to prevent the world from going down a destructive path. Azal remembered what Quratulain said about the future getting worse without dismissing the reality that violence against Muslims, Black people, people of color, and other marginalized groups existed in Azal's present. Azal wanted to be committed to working towards a better world. Not just for the people of today, but for the children of tomorrow. All of us can make a difference, Azal thought.

She walked into her bedroom and saw something shining on the floor. She reached down and picked it up. It was the turbah that the woman in green had given her, the same one that Azal would give to Quratulain many years from now. Azal held the clay stone next to her 
window, watching it glisten in the sunlight. The Arabic inscription "Ya Fatima" shined. She smiled. 


\section{Pilgrims Descent \\ J P Heeley}

Author Bio: When he is not writing science fiction and speculative fiction $J P$ Heeley works with entrepreneurs and larger companies to deliver technology driven innovation. He as done this both as a venture capitalist, and now within a large media company. This has fuelled his interest in how technology and society interact - his stories explore the personal narratives that arise from that interaction. His story Child's Play was recently published as part of Intel's Tomorrow Project. He lives in London with his wife and two boys.

Salat

The Earth's grey face shone brightly through the algae haze. Grey clad pilgrims hopped rhythmically alongside the pool's edge. The oasis, glinting back the Earth's light, was still thirty minutes away; thirty minutes along the gentle arc of the algae's edge.

An electric wail broke through their headphone's hiss, calling them to a halt. As one they broke their hops, stumbling to a stop, raising a puff of dust that billowed and hung around them. They set their canisters down and unstrung the bags from each others' backs, unpacking the makeshift musallah. Memory-cloth stiffened to twice their height, gaping to accept the ablution tents. Each section grasped the other, blending to an airtight bond.

The cloth behind them closes tight as they pass through the entrance membrane. They lift their helmets, eyes cast down, breath held. 
'Allah akbar ...' whispers one, with the last of his breath

'Allah akbar.' Return the pilgrims, drinking hungrily at the half thin air. Gloves, shoes and one piece suits are divested and placed tidily, ready for redonning. They take handfuls of dust from the floor and work it carefully into their arms, legs, feet and faces; the dry ablution of scarcity.

The time worn chant summons them to the musallah where centuries old horizontal tradition is honoured vertically, with a crouch and full stretch stand, arms lifted toward the Earth, toward Meccahome.

Oasis

Crack-lipped the band make the dust summoning stop at the station. Its scarred metal shell bearing witness to its age, to the Beginning. The old airlock swings open, and a single seater rolls out towards them.

'Can I help you?' the voice rang clear in each of their heads, a slavonic accent persisting through the century.

'Forgive us' Ibrahim spoke for them 'we are pilgrims on our way to Canaveral. Forgive our trespassing on your property. It should only take us two days to pass through.'

'Well, I'm sure that is $O K^{\prime}$ the vehicle spoke to them all, but pivoted towards Ibrahim. 'But if you are looking for a space to rest, I have an old garage out back. You can rig the processing outflow, its rich enough for a night's sleep.' 
'God protect you my friend, your kindness to strangers honours you.'

'Never mind that. It's the decent thing to do out here.' Ibrahim knew well the tradition of hospitality of the pool farmers, but it did not always hold for groups of pilgrims.

The tent village filled the garage, strung between the vacuum pristine abandoned vehicles. The garage stretched twenty foot above them. A luxurious space only made possible by the generous overflow of the pools. The air was thick, rich, yeasty. A fruity gag-inducing change from the ozone of their too processed suit air.

The twelve couples made their just-for-today-homes around a centre, where the blanket marked out their common space. They sat measuring out their rations, separating the favoured morsels as a gift for their host.

Dimitri joined them, a private oxy-thread discretely feeding enriched air to his nose.

'Just wait there.' He called, uncoiling the wide hose towards their centre. 'You got any containers? Big ones? ... Well go get them, I've got some prime raw mush on tap here. See what you can make of it.'

Just as the Not-Chosen had told them. Pilgrims can rely on the kindness of the pool famers to set them up for the plain. Inshallah. The mush glooped into the three gallon bags, four filled deep with grey pungence. Salvador took over, setting out the stovebox and separating the mush into fifteen pots. They would feast tonight. He set their tasks and gave each the carefully crafted spice sachet. 
Ibrahim and Sarah were given the sweetmeats, drying some precious water from the mush and working in the honey, rose and lemon flavour. Half was mixed and shaped into sweets. The rest rolled with an admix to make a pastry which was rolled paper thin into baklava.

One for the feast, one for the journey and two for the host. The pilgrims deal. Dimitri thanked them as he took the trays back to his home. He returned with four large jugs, held two to a hand and carefully topped to avoid spillage.

'Pure mush juice ...' he slammed the first two jugs down. The pilgrims fixed grins of gratitude did not mask despair at the thought of sustenance hard to keep down.

'Something to take the edge off ...' they found the third to be heavily dosed with mint and sweeteners, bearable in small doses.

'... and something a little special ...' he removed the lid and raised it to his nose, breathing the volatile vapour.

'That is not for us I'm afraid' said Ibrahim, his hand held over the last jugs mouth.

'Your choice. Others of your type do you know?' Ibrahim just smiled as Dimitri downed a small glass of the liquor.

Bad news by the pool-side

The pilgrims strapped the last of their bundles to the crawler. They sat awkwardly atop the vehicle, its sharp edges jabbing their behinds as it bumped over the rocks in its well trod path. The crawler 
would take a full day to follow the arc of the pool, a day lit bright by the Earth's face, reflecting glaring light across the Moon.

The pool stretched away to their right. Its surface rippled by wavelets from the subs, stirring and treating. Raw mush. Volume, not precursor. Their destination, the pumping station, rose above the pool ahead, flanked by solar panels, pumping finished mush to the pipeline. Piped back to Canaveral where people huddled round the processing plants.

Prayer was personal on the crawler. No space to raise their tent, each observed in their own way, raising their hands upwards towards Earth's grey face at the appointed time. Sarah prayed hard it wasn't true.

'Let me see.'

'Again?' Sarah, eyes downcast. She passed him the device. A simple multi-sensor, its stick still protruding from the slot.

'Yes' it said in plain blue font, then 'ten days approx.'

'We are blessed.' Said Ibrahim, flatly.

'But the Not-Chosen will never send us. No one martyrs the unborn.'

'It's the will of Allah dear. If we are chosen, it is His will. If our child is to enter paradise before he is born, he will be blessed.'

'And if we choose not to go? That is Allah's will too. We can choose that. Stay here, in Canaveral. Have the baby, bring her up. We can live that life.'

'With what? We've sold our home. Sold our jobs. The Hajj is our life. If we are chosen, inshallah, then will shall be together in paradise. Trust Allah my dear. He knows our path.' 
A sharp warning screeched in their ears, breaking their debate. The crawler stopped quickly, causing unstrung goods to roll forward across the top of the vehicle and tumble slowly to the ground below. The pilgrims followed, at a controlled pace, gathering their goods around them.

\section{The Great Plain}

'Get the rhythm right and you will cross in four days.' The Not Chosen had told them. Months of training had prepared them for this stage. Building. An hours hop. Then two. Then four. Finally the full day's journey - loaded. But the training loads were lighter, not as bulky as the full pilgrim pack. Prayer-loads and provisions. And the path more hazardous. Rock strewn, craterful. More than once a pilgrim lost his footing, rolled down dust draped into the blackened shadow of a depth.

Venting was a risk. Ripping falls letting life ebb out of the tear. The pilgrim had to work fast. Break open the pack and smear the binding gel. Watch it bubble, then fix, edges straining. Then patch. Flat on the gel, pressing the edges hard to stimulate meld. Then paint the skin, yellow to remind the owner the suit is no longer fit for use. Needs to be replaced for the next trip. Except there was none to replace it with. So they continued, yellow striped hazard spreading.

The party began to stretch out.

'Go at your own pace.' The Not Chosen had told them. 'Better stick to your own rhythm and catch up at prayers than hop in false rhythms.' 
They'd tried it of course. In exercises. Keeping up or waiting for stragglers. But the exhaustion was complete compared to the natural trance inducing metronomic hop. One-two, one-two, one-two, one-two.

But the party began to stretch out.

Fatima was distraught as they set up their tents. Alex wasn't there. Was not there before them. No one had seen him. Not since al'asr. She widened her radio's scope, haemorrhaging scarce power, but nothing. No calls. No direction.

'I'll wait' she said the next morning. Unpersuaded. It was death of course. The Not Chosen had warned them. 'The plain takes half', that was the Pilgrim saying, 'One tenth through accident, and four through fruitless compassion and stupidity'.

Alfred, Sophia, Abdul and Claire, Salvador and Simi. All lost on the second day. Abdul had clambered down the the steep crater, where the fall had snapped Claire's leg. They turned off their headsets as he struggled to get the bone back into the suit, painting layer on layer of yellow. Salvador, Alfred and Sophia failed to show at the end of the day. But they all saw the tragi-comic demise of Simi. Her three-step hop, unique amongst them.

One-two-three-jump, one-two-three-jump, one-two-three-jump. Except as she was closing on the camp it was one-two-three-flail. She'd hit a rock that scampered away as her weight pushed down. Her jump, out of control, sent her spinning towards a rock field. She held her arms out, protecting her face from the first of the rocks. They saw the rock's edge rip her sleeve; her arm flapping free from the suit; all her air rushing out. Then her helmet, her head, her face hit the next rock. A 
sharp click in their headsets and nothing else. She didn't move, nor did they.

The third day. The half food day. Thin air day. Rations carefully balanced to get them to Canaveral. No more, no less. They could do the last day on an empty stomach. And this second to last, the pickings were thin. But the air was the test. The hopping walk was greedy for oxygen. They all drank too deep in the first days. All of them. All pilgrims. Always. But they paid the price. Dial down the oxygen. CO2 rich air. Their limbs begging for mercy as they pulled on their suits inside their tent-domes. The day was brutal. Only ten made camp that night. The party's couples had thinned to three, leaving four bereft to mourn the night. The couples retired to their tents leaving the forlorn sharing their grief.

'I'm sorry' said Sarah, scraping the mess from the yellow-striped legs of her suit near the tent's door. The scent of the vomit filled their dome.

'No, never mind.' A bleary eyed Ibrahim mumbled from his sleep reaching out to comfort.

'It's the baby dear. My pregnancy. I've got the bloody sickness.'

'It'll be OK. Here, have some of the water.'

'I tried. I can't keep it down. Bloody yeasty, can hardly let the smell near my nose.'

'You must dear. You can't do tomorrow without. Try this.' He'd found one of the canisters that had been forgotten from before the farm. Sarah took it gratefully and swigged deeply. She waited, eyes rolled upward, feeling for the nausea that did not come. So she drank again.

'That's enough,' said Ibrahim. 'let's save it for tomorrow'. 
The fourth day started with their prayer call, honoured in their tents. The pilgrims emerged ready for the last leg. Crackles in their earpieces taunted them, hints of population ahead.

Dust trails marked their passing as they fanned parallel paths to keep their sight clear. Sarah's stride widening a gap from Ibrahim's more gentle lope. Each jolting step shot pain in his hip, legs begging him to stop. He let the pilgrim's prayer cycle through his mind, lips twitching the words but reserving is breath for the walk. Eyes, mind, feet; eyes, mind, feet; eyes, mind, feet. Instinct not thought guiding his steps. His breath became shallow in his trance. Just enough for movement. The limbs' pain outside his mind. There, but somewhere else.

He would have passed Sarah, her yellow striped back arched towards him, if the rock had not rolled beneath his feet, bringing his heel down hard and shaking a gasp from him. His trance was broken.

Yellow. He registered. The non-Moon colour. Bright stripes calling him. He caught the sobbing in his radio.

'Ibras...Ibras ...'

'Sarah.' He jumped to her side, pulling her to him in a suit encumbered embrace. Her visor was smeared and sloshed. He pressed his own against it, letting his voice carry from glass to glass to her.

'Come on my love. Let's rest up. Put up the domes. We'll clean you up.' 
They pitched the tents, their tombs. Food, water, air all near finished. They faded to sleep, Ibrahim's arm circling Sarah's belly, cuddling his son. But Sarah twitched and straightened, her muscles yearning for oxygen. It woke them both.

'Ibras.'

'hmm' his arm stretched out across her, his face relaxing back to torpor.

'Let's go, Irbas. Let's walk it. Together.'

'Hmm? We won't make it. No one can. Let's just sleep. Rest.'

'Ibrahim. No. I wan't to try ... walk 'til I drop. Not give up here... I owe it to Alia, she stroked her stomach, I'm taking her Home.'

Fifth day of four. They tethered their tanks, sharing the last of their air. The last of their water was gone before their helmets were on. No energy for hopping, they trudged an arms length apart.

Minds were lost, both sharing nausea, stumbles and falls, yard by yard they trekked. Time lost. There were crackles. Growing, insisting, ignored. Rounding the rock they caught the twinkling of the ariel's end. Far on the horizon. Marking where they would not, could not reach.

Ibrahim fell. Footing missed he drifted to the floor. Elbow, first. It caught something and puffed vital air. The tether tugged Sarah to fall beside him. They lay facing each other. Ibrahim could see Sarah's urgency through her visor as she pushed herself up again, on all fours.

'Come ... on ...' she pulled at Ibrahim's arm. The Earths reflection masked his face from her, masked the tear strewn defeat.

'Come on!' her strangled call came through. Then snap. Her grip lost and she fell back, rolling like an upturned turtle. 
So they stopped. Enough. At last. Their hands found each other. Solace muffled by cumbersome gloves. The prayer call sounded again. Mecca was marked in their helmets. A small red dot superimposed on Earths looming face above them. Gripping fingers they mouthed the prayer as the world closed down around them.

\section{Deciding Death}

The noise, the light, unfolded slowly from from vertiginous confusion. Swirling slowed as thoughts cohered.

Alive.

The buzz of lights asserted in the background. Ribs of prefab plastic familiar above her head. Something held tight smothering mouth and nose. Clean and rich air. An interior room. No window.

Inside. Rescued.

Showered and dressed they stepped, stiff legged towards The Not Chosen's door. Not the, The. The first. First to return. First to bring the new new pilgrimage. The successful pilgrims reward, an audience. Selection still lay with The Not Chosen.

Silver haired with a neatly trimmed beard, The Not Chosen sat behind a simple wooden desk. Wood. An artefact from Before. They approached, eyes cast towards the simple table top, arms outstretched holding their pack, suit and canister.

'A gift from pilgrim to pilgrim.' They said the form.

'A pilgrim thanks you.' He replied.

'Seed for our future.' They placed canisters on the desk. 
'Inshallah' was the only response. Then with a smile, 'Please take a seat, you have travelled far and deserve a sit down.'

Two assistants had silently joined them, holding chairs, padded comfort. Ibrahim and Sarah, struck dumb, gratefully sat. The assistants reached around them, taking the suits, packs and canisters from the table and retreated through the door.

'Hard to see them go.' The Not Chosen said quietly behind their turned heads. They snapped their attention back.

'Your suits, their earned stripes. No good to anyone now, except as primary material.' He looked them both in the eyes. 'Far more valuable to you. They shall be returned if you are not selected. If you are ... then you will have no need.'

'Thank you.' Mumbled Sarah, still avoiding those eyes.

'Come on.' The Not Chosen said, voice lightening. 'You made it. Be joyful. Let me serve you.' One of the assistants had returned. A silver metal tray, with tea pot and a plate of sweet meats. The Not Chosen poured the tea, lifting the pot as punctation. He stood and handed the cup with a bow. First to Ibrahim, then Sarah. He then took the small tongs and selected three sweet meats a piece for their plates.

'You honour us, Not Chosen.' Ibrahim said, still stiff.

'So, you want to complete the Hajj? You want one of the seats. Two of the seats.'

'Yes' said Ibrahim. 'We have completed ..'

'You both want to complete the Hajj?'

'I ..' Sarah hesitated. Ibrahim turned to her, staring intently at the eyes that avoided his. 
'We do,' he said, eyes still on Sarah 'it's our dream, we have dedicated our lives ...'

'And you are blessed by Allah.' Ibrahim's attention snapped back to The Not Chosen, whose eyes were holding Sarah's.

'We are truly blessed, Not Chosen,' Ibrahim insisted 'Allah saw us through our pilgrimage, brought us to you when all was lost, and ...'

'And you, my child, are blessed.' The Not Chosen stood from his chair and stepped to Sarah's side, lifting her head to face him.

'We ... what?' Ibrahim continued.

'We know about the child my son.'

'But it doesn't diminish our calling Not Chosen.'

'Doesn't it? Daughter? Doesn't it?'

'I don't know.' Sarah said finally. 'Surely our child deserves its life, inshallah. It is not for us to answer the call for her.'

'We must for our children, child, it is our burden. Your burden. None of us can tell you what to do.' He looked pointedly at Ibrahim. 'None of us.'

He took her by the elbow, gently lifting it so she stood. 'Come child let us talk.' They stepped to the door at the back of the room.

\section{Aboard the bullet}

The straps clasped them as the shell was sealed shut. Eight pilgrims, four couples along the length of the inert bullet. Waiting to be shot. Ibrahim turned towards Sarah, but their helmets clanked, unable to crane forward to see her face. 
'Love you.' He said as the bullet lurched forward. Pressure squeezing his breath, harder and harder. Their seats inclined as the bullet angled up the accelerator. Each pilgrim isolated in his own electronic silence. Until, just as suddenly, it stopped. The pressure cut off and they eased forward against their restraints.

'You OK?' Ibrahim asked Sarah.

'Just holding it in ... let me be' her nausea rising again.

'Don't worry about being sick' The Not Chosen had told her 'They're all sick up there, you'll blend right in.'

She longed to free her head and retch bile, but the bullet was not pressurised, she was stuck in her helmet.

'Just train.' The Not Chosen had told her. 'Give yourself the option. It will be good for you whatever you decide.'

The regime had been tough. Building body strength. Twice a day with weights, breaking down and building up muscle. And daily endurance hikes. Slow paced in weighted suits. Their bodies changed, built definition. She admired the shape of Ibrahim's shoulders, and the solidity of his swelling thighs.

The Not Chosen continued to pay her special attention. Meeting with her after each evening prayer.

'Sarah, you must understand. Death is not the destination, it is not the pilgrims aim. Paradise Sarah. That is what you seek. A paradise back on Earth.' She protested that paradise was only found through death. It was naïve to pretend otherwise.

'Do you think the Chosen are simply dead? That they are not in paradise?' 
'They are Chosen, blessed. They have found paradise.' She parroted her pilgrims teaching.

'Then you too will find paradise Sarah, inshallah. And you will take your child, your Alia, with you. She will not have to endure our lives, the struggle here. She will live with you in paradise.'

He worked on her will. As did Ibrahim. As did the group. The Hajj was their life, their all. Rumours were rife. Successive pilgrims had rebuilt the Kaaba in its spot. Each year one pilgrim was selected from the group and given food any oxygen enough to welcome the next year's pilgrims while the rest of the party walked into the wilderness to die. No ship had yet landed safely. Mecca was surrounded by crashed pilgrim ships while the Not Chosen had simply abandoned the pilgrimage. That having completed the Tawaf the pilgrims' spirits were raised directly to heaven. That ...

Thump. The bullet shuddered as the orbital oasis grappled it to its belly.

'I shall follow Allah's will. Put myself in His hands.' She'd said the form of words, submitting herself to selection. Ibrahim's smile filled his face as his newly strong limbs hugged her.

'We shall be twice blessed, I know it.' So did she.

So it was no surprise when their names were drawn. When she found herself being dressed in the white suit of the pilgrim, being sealed into the bullet that would shoot her to space.

\section{Weight}

It was a short EVA to the drop-plane, an alien delta wing from storybooks. As he waited his turn outside the plane Ibrahim watched 
the bouquet of store-capsules squirt towards the dark Earth below. The first was trailing a thin glow behind it, fire from the diminished atmosphere towards the bleak and dead below.

He strapped himself into the rosette of pilgrims, knee to knee with their provisions piled between them. Prayers said, pinned in place, the plane gave a shudder as it was jolted out of orbit with a twist as it reorientated itself for descent. Sarah reached for her bag - joined by three others going green as the capsule rolled and jolted into the atmosphere. The rumble turned to a roar as they jostled shoulders in their seats. Silence descended as the noise blocked any voice.

The rattling roar turned to sickening swoops as the glider banked to lose more speed. The pilgrims began to feel the Earth's unrelenting embrace as the plane settled to its approach. Buttocks pressed hard into the seats ungiving surface, heads and shoulders aching to slump forward. They pressed the masks to their faces, sucking deeply on the relaxant rich air, creating a head-swimming high.

The crunch of the landing sent limbs flailing, striking companions, causing a bloody nose and a blackened eye. Their harnesses however held their bodies firm as the plane strained and creaked against the opening parachutes. Sarah, back towards motion, was pressed into the chair, spared the worst of the strappings grip. She stroked her tummy. 'Welcome home my Alia, she whispered.'

There was a moment of silence from the pilgrims in the halted craft, the jingle of straps hanging from the craft providing a mesmerising call.

'Allah Akbar' came a voice.

'Allah Akbar' returned the others. 'Allah Akbar!' the voices grew with cheers of relief and joy. They descended into excited chatter. They 
were here. They were on Earth. They were and they had made it. Soon the door would open they would be there. Mecca.

Click. The harnesses released.

One of the pilgrims made to stand up, but fell back to his chair. Defeated by the pull. The man next to Ibrahim remembered his teaching. He moved his hands to the back of the armrests, took the strain, leaning his head forward and slowly straightened his legs, carefully releasing his grip. He swayed and grunted, the pilgrims all pinned down with bated breath willing success. He raised his right arm, flailing it as his leg began to collapse under his weight. But he caught the bar above his head, arresting his fall and swung painfully, one handed. He threw the other hand up and grabbed the bar, righting his legs below him and stretching until his arms were half bent. 'Come on ...' he panted 'its fine up here ... what are you waiting for'.

One by one the pilgrims hauled themselves up, gasping and straining. Their exercises had prepared their bodies, but not their minds. The oppressive weight driving all thought from them as they struggled to remain upright and move around the plane.

The door cracked open, sucking the air from the ship and their lungs. Ice cold, thin air stung their faces as the gentle breeze of their respirators blew warm life over their mouths and noses before it dissipated into the depleted atmosphere. The sky outside was a blinding haze. A blue-grey glow. Everywhere. No source. The entire sky was glowing. They'd seen it in movies of course. Old movies from Before. But the weight, the light, the cold were overwhelming. Iced tears were shed as they shuffled down the ramp clinging for security to its rails. 
The world stretched ahead of them. Not the foreshortened lunar horizon, but further, further than they had seen before. Cracked, creased, bent and stressed. Frozen folds and melts rolled and lurched to the left and right. And amongst them misshapen metal balls and darts, their contents disgorged and used. But this was a sideshow to the black block standing alien ahead. Not the flat narrow slab of other stories, a bloated tall cube. The cube of their dreams, ancestors, faith. Kaaba.

They slept first. None physically or emotionally ready for the ritual. Their tents expanded, rigid against Earths gravity. And inside giving gel mattresses swelled and cushioned them in pseudo-buoyancy, taking the load from their exhausted limbs.

After the Ritual

The pilgrims share the feast. Aching limbs subdued by the elation of completing their Hajj. They had done it. Them. Just the eight of them. No more. Eight a year. And it was them. Their names would live with the living and their souls would live in paradise. They sing their joy and feast on the special meats. Nothing to save. No need. Nowhere to go. Just a day and night. Then the short trip to paradise.

Ibrahim and Sarah lie side to side. Gel hugging and supporting them. Unbidden dreams muffled their joy that night. Earths oppressiveness bringing shortness of breath, dragged underwater, or caught in dust slide. Ibrahim woke with a start, images of Sarah and his son being sucked into the ground, while wind blew heavy against his chest.

He ached, the deep muscular pain of unfamiliar exercise. He rubbed relaxant into his thighs and arms, wincing at their pain as he 
kneaded himself. He swallowed a painkiller and pulled on his suit, strapping the half mask over his mouth.

'Sarah!' he called from the entrance of the tent. 'Sarah, get up!' and turned back to face them. The other pilgrims stood frozen at their tents too.

There were five of them. Five adults. Earth shaped. Standing between the the campsite and the path to the Kaaba. They stood with easy confidence against the Earth's gravity, blue cloth scarves worn around the mouth and over the head. And in their midst were children. Three of them, no four. Dashing with excitement at their feet. Dashing with ease. Earth-born ease.

The adults gait was less easy as they crossed to the camp, but the Pilgrims eyes were drawn to the children who ran without care towards them.

'Hello, hello!' They cried. 'Welcome!' 'Allah Akbar'. And then they were in the midst of the Pilgrims. Giggling, stroking.

'No!' called one of the adults, tearing the scarf from his mouth, showing the breathing tube beneath. But the child had grabbed the knees of one of the pilgrims, whose uncertain feet were soon lost, resulting in an all too fast crash towards the floor.

The strangers helped the pilgrims, lending and arms and good spirits in a short trek beyond the Kaaba. There was parked a fleet of coffins on wheels. The coffins were filled with a gelled liquid. The strangers helped the pilgrims into the welcome buoyancy, providing relief from the Earths greedy pull. 
'Lie back. Relax. Sleep.' The stranger would say lowering a mask onto each pilgrim's mouth. They drifted off to the gentle rock and slurp of the gel coffin.

\section{Paradise}

Ibrahim gasped as he hauled his torso out of the gel. They'd stopped in a broad crack in the ground, a rift. Some three to four hundred meters across. It snaked forward and twisted out of view. On the ground stretched the familiar blue green algae pools, with oxygen tanks and converters dotted along the pools' sides. The walls were cut with openings. Some laid open, stores of equipment and mush. Others were closed shut with sealing curtains, shutting in life and air. And amongst the pools walked suitless people, half masks enriching the thin air, dozens of them. Many were bent over from straining against gravity; others, conquering it, were standing proud on earth shaped thighs. And then there were children. Earth born children. Making light of the weight. Sons and daughters of paradise.

So that was why they were there. That was the selection. Not despite of their pregnancy, but because of it. Allah had called them and tested them. And their reward, an Earthly paradise. It would be flawed for them. Flawed as each day they struggled to move, to walk, to breathe. But their unborn - she had true paradise. Born back on Earth. An opportunity to start again. 
Editor Bio: Muhammad Aurangzeb Ahmad is a Senior Data Scientist at Groupon Inc and a researcher at the Department of Computer Science at the University of Minnesota (UMN) and research associate at the Center for Cognitive Science at UMN. His work involves behavioral modeling, optimization and machine learning related problems. His current research interests are extraction and analysis of massive social networks from historical sources, (technical challenges as well as ethical implications of) making simulations of deceased people and (historical and contemporary) cultural analytics of the Islamic(ate) world.

He has a PhD in Computer Science from UMN where Professor Jaideep Srivastava was his academic advisor. He also worked extensively with Dmitri Williams at USC, Noshir Contractor at Northwestern University and Marshall Scott Poole at UIUC on virtual worlds related projects. This research work resulted in a spin-off from Professor Srivastava's lab - Ninja Metrics which is a social analytics start up. During grad school he was a research assistant at the Minnesota Population Center where he mainly worked on the IPUMS project on the application of machine learning to population studies. He was also a research intern at Boston Scientific where he worked on data mining Implantable CardioverterDefibrillator (ICD) data. He completed Bachelors of Science in Computer Science with honors from the Rochester Institute of Technology with minors in Philosophy and Mathematics. During his undergraduate years at the Rochester Institute of Technology he was also research assistant at the Center for Advancing the Study of Cyber Infra-structure where he worked with Professor Ankur Teredesai.

His work as an artist is at the intersection of mathematics, multiple cultural traditions and digital humanities. He knows Arabic, Chinese and Hebrew Calligraphy. He is the inventor of Kordu a polysemic script that can be simultaneously read from left to write in Korean and right to left in Urdu. He also invented Silicon Arabic which is calligraphy done with Computer Circuits. Muhammad Aurangzeb Ahmad is the founder and editor of the Islam and Science Fiction Project. He has also given talks on panels at different fan conventions (Cons) on this subject. The Islam and Sci-fi website is the most comprehensive resource on the subject. He also writes for Three Quarks Daily (3QD) as a columnist.

\section{Contact:}

Website: http://www.aurumahmad.com/ 


\section{The Islam and Science Fiction Project}

On the web: http://www.islamscifi.com

Facebook: Islam and Science Fiction Facebook Page

Twitter: @islamscifi

Email: islamscifi@gmail.com

Cover art designed by Muhammad Aurangzeb Ahmad 